\author{
UNIVERSIDADE DE SÃO PAULO \\ FFCLRP- DEPARTAMENTO DE PSICOLOGIA \\ PROGRAMA DE PÓS-GRADUAÇÃO EM PSICOBIOLOGIA
}

\begin{abstract}
Fatores comportamentais, hormonais e neuroanatômicos associados à vulnerabilidade ao estresse em ratos Carioca High Conditioned-Freezing (CHF) e Carioca Low Conditioned-Freezing (CLF)
\end{abstract}

Laura Andrea León Anhuamán

Ribeirão Preto 
UNIVERSIDADE DE SÃO PAULO

FFCLRP- DEPARTAMENTO DE PSICOLOGIA

PROGRAMA DE PÓS-GRADUAÇÃO EM PSICOBIOLOGIA

\title{
Fatores comportamentais, hormonais e neuroanatômicos associados à vulnerabilidade ao estresse em ratos Carioca High Conditioned-Freezing (CHF) e Carioca Low Conditioned-Freezing (CLF)
}

\author{
Laura Andrea León Anhuamán
}

Tese apresentada à Faculdade de Filosofia, Ciências e Letras de Ribeirão Preto - USP, para a obtenção do título de Doutor em Ciências. Área de concentração: Psicobiologia.

\author{
Versão Corrigida \\ (versão original disponível na FFCLRP)
}

Orientador: Prof. Jesús Landeira Fernandez PhD

Ribeirão Preto 
AUTORIZO A REPRODUÇÃO E DIVULGAÇÃO TOTAL OU PARCIAL DESTE TRABALHO, POR QUALQUER MEIO CONVENCIONAL OU ELETRÔNICO, PARA FINS DE ESTUDO E PESQUISA, DESDE QUE CITADA A FONTE.

\section{FICHA CATALOGRÁFICA}

León A., Laura Andrea

Fatores comportamentais, hormonais e neuroanatômicos associados à vulnerabilidade ao estresse em ratos Carioca High Conditioned-Freezing (CHF) e Carioca Low ConditionedFreezing (CLF) / Laura Andrea León Anhuamán; orientador Jesus Landeira Ferdandez.

- Ribeirão Preto São Paulo, 2013.

$111 \mathrm{f}$.

Tese (Doutorado- Programa de Pós-Graduação em Psicobiologia. Área de concentração> Psicobiologia) - Faculdade de Filosofia, Ciências e Letras da Universidade de São Paulo.

1. Vulnerabilidade ao estresse. 2. Fenotipagem. 3. Ansiedade. 4. Corticosterona.

5. Neurogênese. 6. C-FOS. 7. Ketanserina. 8. Labirinto em Cruz. 9. Carioca High Freezing, CHF. 10. Carioca Low Freezing, CLF. 


\section{FOLHA DE APROVAÇÃO}

Laura Andrea León Anhuamán

Fatores comportamentais, hormonais e neuroanatômicos associados à vulnerabilidade ao estresse em ratos Carioca High Conditioned-Freezing (CHF) e Carioca Low ConditionedFreezing (CLF). Tese apresentada à Faculdade de Filosofia, Ciências e Letras de Ribeirão Preto - USP, para a obtenção do título de Doutor em Ciências.

Área de concentração: Psicobiologia.

Aprovado em:

\section{Banca Examinadora}

Prof.

Dr:

Instituição

Assinatura

Prof.

Dr:

Instituição

Assinatura

Prof.

Dr:

Instituição

Assinatura

Prof.

Dr:

Instituição

Assinatura

Prof.

Dr:

Instituição

Assinatura 
A mi hermano Javier e a mis padres Jonás e Martha, dedico. 
Este trabalho foi realizado no Laboratório de Psicofarmacologia em colaboração com o Prof. Dr. Marcus Lira Brandão do Programa em Psicobiologia da Faculdade de Filosofia, Ciências e Letras de Ribeirão Preto da Universidade de São Paulo (USP-RP), no laboratório de Neurociência e comportamento do Departamento de Psicologia da Pontifícia Universidade Católica de Rio de Janeiro (PUC-RJ) sob orientação do Prof. Dr. Jesus Landeira Fernandez (Programa de Psicologia da PUC-RJ), no Laboratório de Neurobiologia da Retina, em colaboração com a professora Dra. Patrícia Franca Gardino (Programa de Neurobiologia do Instituto de Biofísica Carlos Chagas Filho, da Universidade Federal do Rio de Janeiro, UFRJ), no laboratório de Fisiologia do Departamento de Fisiologia, Faculdade de Medicina de Ribeirão Preto, Universidade de São Paulo (USP-RP) em colaboração com o Prof. Dr. Celso Franci, no laboratório de Neurociencia e Comportamiento de la Universidad de los Andes, Bogota em colaboração com o Professor Dr Fernando Cárdenas . O trabalho foi desenvolvido na vigência de auxílios concedidos pela Coordenação de Aperfeiçoamento de Pessoal de Nível Superior (CAPES). 


\section{Agradecimentos}

Á minha família por apoiar e entender minhas ausências. A todos los Leones e Anhuamanes. Ao Prof. Dr. Jesus Landeira Fernandez por orientar este projeto e apoiar as minhas ideias.

Ao Prof. Dr. Marcus Lira Brandão por abrir as portas do seu laboratório e permitir a realização desse trabalho.

Ao Prof. Dr. Celso Franci por permitir as dosagens de corticosterona no seu laboratório e ao técnico Rogerio Rosário de Azevedo por realizá-las

À Prof. Dra. Patrícia Franca Gardino pela ajuda nas imunos de proliferação celular e neurogênese.

Aos Professores Dr. Wagner Ferreira, Helio Zangrossi Jr e Silvio Morato por participar do meu exame de qualificação e pelas sugestões.

Ao Prof. Dr. Fernando Cárdenas por me trazer ao mundo da neurociência, pela sua paciência, sugestões, grande ajuda, amizade incondicional e carinho.

Ao Dr. Vitor Gomes pela amizade, ajuda e orientação neste trabalho. Pela leitura e sugestões. Foi muito importante contar com você. Principalmente nos momentos de pânico.

A Daysi, Santi Zarate e Nicolas pela ajuda técnica, amizade e bons momentos de laboratório.

À Laura Pulido e à Marly Uribarren minhas filhas acadêmicas, melhores amigas e colegas. Por manter essa amizade mesmo de longe e ficar sempre perto. Adoro vocês.

A Sara Hott porque nela encontrei uma grande amiga para todas as ocasiões. Minha irmã mineira. SM. Com a que sempre lembro que o mundo é perfeito.

À Dra. Amanda Ribeiro e ao Dr. Adriano Reimer pela grande amizade, por me adotar, orientar e corrigir sempre que precisei.

Ana e Renata pela paciência de ter me aguentado, ouvindo e aconselhando quase todos os dias a quase todas as horas, dentro e fora do lab.

Ao Dr. Lucas Albrechet pelos dias e aventuras compartidas.

Às doutoras Milene Carvalho e Karina Genaro pelo carinho e companhia.

A Fernando Midea por sempre estar disposto a uma boa troca de ideias.

Ao Professor Dr Jorge Nobre por alegrar os almoços.

Aos amigos dos laboratórios do Rio: Carlos, Erica, Mario, Silvia e Carolina Irurita.

Aos amigos do meu Laboratório de neurociencia e comportamento Uniandes: Jevra, Ro, Johanna, Melissa, Santi Roa, Andrea Zarrate, Minnie, Michel, Andresito, Christian, Cesar, Enrique, Laura Moreno, Lina e todos os que mesmo estando longe me fizeram sentir parte do grupo, porque são como minha família e adoro vê-os crescer. 
Aos meus amigos neurocientistas ou não que sempre estiveram dispostos a me escutar e me ajudaram a não perder a sanidade e saber que existe outro mundo além da neuro: Diana $P$, Evita, Nata, Paula, Karen, Diego, Bambito, Pipe, Danilo, David C., Fajardo e os últimos mas não menos importantes Camila, Hugo, Eliana e André.

À professora Andreia Schmidt pela orientação no PAE grande exemplo de professora.

À professora Dra. Sâmia Joca e ao Professor Dr. Leonardo Resstel que me serviram de inspiração e exemplo pela humildade com a qual sempre estiveram dispostos a falar comigo. Principalmente por abrir as portas dos seus laboratórios e me dar a oportunidade de socializar com os seus alunos.

Aos amigos da farmacologia: Deidi, Cassiano, Laura, Daniela, Vitor, Vini, Davi, Alejandro, Leandro, Teo, Andreza e principalmente ao Felipe e a Dani por compartilhar o seu cantinho comigo.

Ao Prof. Dr. Francisco Guimarães, por permitir minhas visitas esporádicas a seus seminários. A Hugo, Katia, Nayanne, Mara, Kelly e Deusa porque sem eles a entrada na psicobio não teria sido uma grande aventura.

À banca examinadora pelo tempo dedicado na leitura desse trabalho.

Ao CAPEE, pela ajuda com a burocracia dos estrangeiros.

À Renata Vicentini pela disponibilidade e atenção.

À minha família brasileira Flavio del Vecchio, Cidinha, Rogerio, Celia e Isis por me deixar ser parte da família.

A CAPES, pelo apoio financeiro.

A lista é grande e sou imensamente grata a todos os que fizeram possível esse presente, espero que nossos caminhos voltem a se cruzar no futuro.

"Um sorriso e um abraço sinceros falam melhor que mil vezes "obrigado". Terás sempre o meu sorriso, e receba agora o meu abraço".

Augusto Branco 
"Somewhere, something incredible is waiting to be known." Carl Sagan

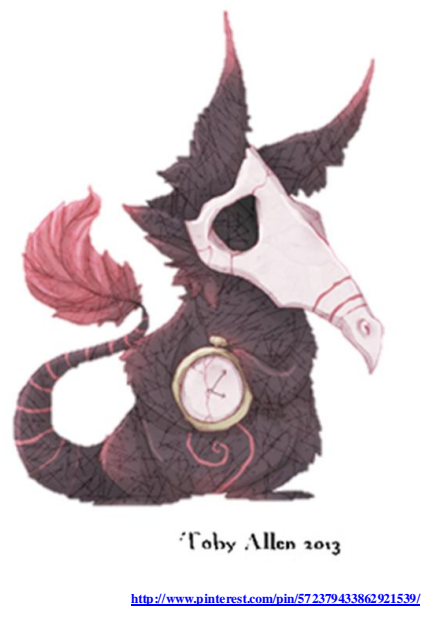




\section{Resumo}

LEÓN, Laura Andrea. Fatores comportamentais, hormonais e neuroanatômicos associados à vulnerabilidade ao estresse em ratos Carioca High Conditioned-Freezing (CHF) e Carioca Low Conditioned-Freezing (CLF). 2013. 111f. Tese (Doutorado) Faculdade de Filosofia, Ciências e Letras de Ribeirão Preto, Universidade de São Paulo, Ribeirão Preto, 2013.

A ansiedade e a depressão são as condições psicopatológicas mais comuns na atualidade. As pesquisas científicas em neurociência, psicologia, psiquiatria e medicina geral procuram encontrar diferentes formas para o tratamento e prevenção. No entanto, a maioria das pesquisas não leva em conta as diferenças individuais ou história do individuo. Quase toda a investigação farmacológica é feita em populações heterogêneas de animais, conduzindo assim à "média" dos dados. Recentemente, no Laboratório de Neurociência Comportamental na Pontifícia Universidade Católica do Rio de Janeiro (PUC-RJ), duas novas linhagens de ratos Wistar foram selecionadas fenotipicamente da resposta emocional de congelamento em um teste de medo condicionado. Uma das linhagens, denominada "Carioca High ConditionedFreezing" (CHF), apresenta uma resposta significativamente aumentada de congelamento no teste, enquanto que a outra ("Carioca Low Conditioned-Freezing", CLF) mostra uma resposta de congelamento baixa. Em todos os experimentos utilizamos a linhagem controle (Random, RND) Wistar resultado de cruzamento aleatório entre ratos Wistar.

Aqui apresentamos dados de diversos experimentos que avaliaram as diferenças em condições basais e vulnerabilidade ao estresse entre as duas linhagens e a linhagem RND. A concentração plasmática de corticosterona dos ratos foi comparada entre as duas linhagens e o grupo RND, primeiramente no nível basal e posteriormente após a exposição ao mesmo teste, onde foram expostos ao medo condicionado, como estímulo aversivo. Também foi avaliada a proliferação celular e sobrevivência. A imuno-histoquímica para c-fos foi conduzida com o objetivo de se determinar as diferenças de atividade neural entre as duas linhagens e o grupo RND. Um teste farmacológico com ketanserina, antagonista $5-\mathrm{HT}_{2 \mathrm{~A}}$, foi realizado e os animais foram avaliados quanto à ansiedade e locomoção, no labirinto em cruz elevado.

Todos os nossos resultados mostraram diferenças estatisticamente significativas entre as linhagens selecionadas. Estes resultados sugerem que as diferentes condições basais podem ter impacto sobre a reação de comportamento exibido por cada animal. Assim, o uso de grupos selecionados é melhor para se modelar transtornos de ansiedade e procurar quais são caraterísticas que protegem aos animais que não apresentam os sintomas modelados.

A partir dos nossos resultados foi evidente que os perfis comportamentais e neuroquímicos dos três grupos CHF, CLF e RND foram qualitativamente e quantitativamente diferentes. Na linha de base após ser fenotipados foi observado que existem diferenças na proliferação celular. Após a reexposição ao contexto observaram-se diferenças na concentração de corticosterona e na ativação neuronal. O estresse crônico levou a respostas diferenciais no número de neurônios imaturos, e o teste farmacológico levou a respostas diferencias tanto a nível local como sistêmico.

Os dados obtidos podem ajudar a um melhor entendimento às bases neurobiológicas de aspectos associados às psicopatologias como ansiedade e depressão que estão relacionadas com a vulnerabilidade ao estresse. 


\begin{abstract}
LEÓN, Laura Andrea. Behavioral, hormonal and neuroanatomical factors associated with stress vulnerability in Carioca High Conditioned-Freezing (CHF) and Carioca Low Conditioned-Freezing (CLF) rats. 2013. 111f. Thesis (Doctoral) - Faculdade de Filosofia, Ciências e Letras de Ribeirão Preto, Universidade de São Paulo, Ribeirão Preto, 2013.
\end{abstract}

Anxiety and depression are the most common psychopathological conditions today. Scientific research in neuroscience, psychology, psychiatry and general medicine seeks to find different ways for treatment and prevention. However, most research does not take into account individual differences and history. Almost all pharmacological research is done in heterogeneous populations of animals, thereby leading to the "average" data. Recently, in the Laboratory of Behavioral Neuroscience at the Pontifical Catholic University of Rio de Janeiro (PUC - RJ), two new strains of rats were selected phenotypically by their emotional response (freezing) in a test of conditioned fear. One of the lines, so called "Carioca High Conditioned - Freezing" (CHF) has an increased freezing in the test, whereas the other ("Carioca Low Conditioned Freezing " CLF) shows low freezing response. In all experiments we used the Wistar control strain (RND) derived from random bred between Wistar rats.

Here we present data from several experiments evaluating the differences in basal conditions and vulnerability to stress between the two strains and RND strain. The plasma corticosterone of rats was compared between the two lines and the RND group, first at baseline and then after exposure to the same test where they were exposed to conditioned fear as aversive stimulus. We also analyzed the cell proliferation and survival in the hippocampus after chronic stress. Immunohistochemistry for $\mathrm{c}$-fos was conducted in order to determine the differences in neural activity between the two strains and the RND group. A pharmacological test with ketanserin, 5- $\mathrm{HT}_{2 \mathrm{~A}}$ antagonist, was performed and the animals were assessed for anxiety and locomotion in the elevated plus maze.

All our results showed statistically significant differences between the selected strains. These results suggest that different baseline conditions may have an impact on the behavior exhibited by each animal. Thus the use of selected groups is better approach in order to model anxiety disorders and to determine which features prevent animal from presenting symptoms.

It is evident that the neurochemical and behavioral profiles of the three groups CHF, CLF and RND were different qualitatively and quantitatively. At baseline after been phenotyped it has been observed that there are differences in cell proliferation and corticosterone concentration. After re-exposure to the context differences were observed in the concentration of corticosterone and neuronal activation. Chronic stress has led to differential responses in the number of immature neurons. And the pharmacological test led to differential responses at both local and systemic.

The data obtained are useful for a better understanding of the neurobiological aspects associated with psychopathologies such as anxiety and depression that are associated with vulnerability to stress. 


\section{SUMÁRIO}

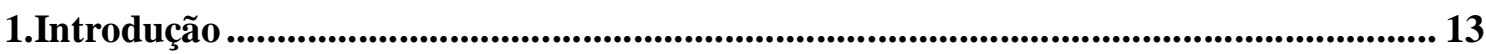

1.1. Variação e seleção ............................................................................................................13

1.2. Vulnerabilidade ao estresse e transtornos associados........................................................13

1.3. Modelos teóricos de Ansiedade e Medo …………………………………………….......16

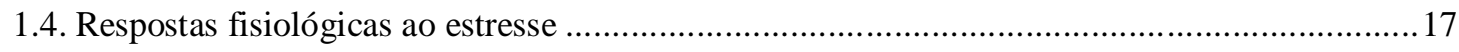

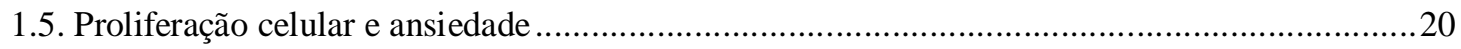

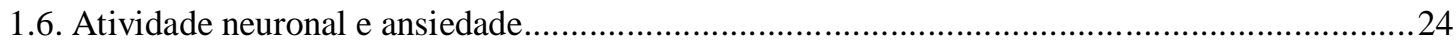

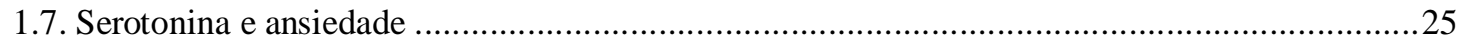

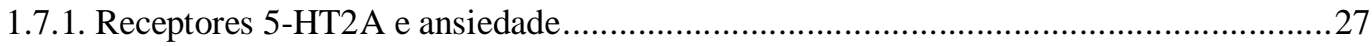

1.8. A seleção da vulnerabilidade ..............................................................................................

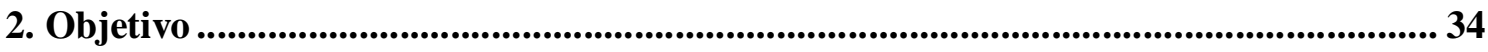

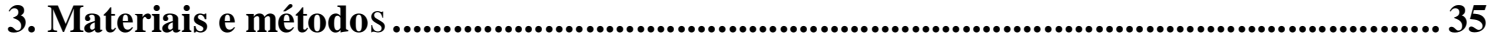

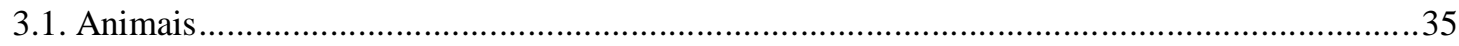

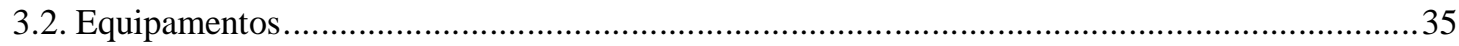

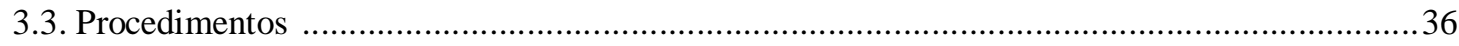

3.3.1. Experimento 1: Concentração plasmática de corticosterona em ratos CLF e CHF submetidos ao modelo de medo condicionado ao contexto …………………………………….....37

3.3.2. Experimento 2: Proliferação celular dos ratos CLF, CHF e RND submetidos ao modelo de medo condicionado ao contexto e a estresse de contenção motora e estresse crônico ...................39

3.3.3. Experimento 3: Expressão da proteína c-FOS nos ratos CLF, CHF e RND submetidos ao modelo de medo condicionado ao contexto

3.3.4. Experimento 4: Efeitos do antagonista serotoninérgico 5-HT2A, ketanserina nos ratos CHF, CLF e RND submetidos ao teste labirinto em cruz elevado..................................................46

3.4. Análise estatística ............................................................................................................ 48

3.5. Considerações éticas ....................................................................................................49

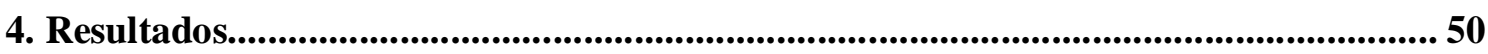

4.1. Experimento 1: Concentração plasmática de corticosterona em ratos CLF e CHF submetidos ao modelo de medo condicionado ao contexto ...............................................................................50

4.2. Experimento 2: Proliferação celular dos ratos CLF, CHF e RND submetidos ao modelo de medo condicionado ao contexto e a estresse de contenção motora e estresse crônico........................51

4.3. Experimento 3: Expressão da proteína c-FOS nos ratos CLF, CHF e RND submetidos ao

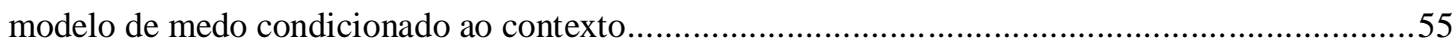

4.4. Experimento 4: Efeitos do antagonista serotoninérgico 5-HT2A, ketanserina nos ratos CHF, CLF e RND submetidos ao teste labirinto em cruz elevado. 
5. Discussão ......................................................................................................................... 70

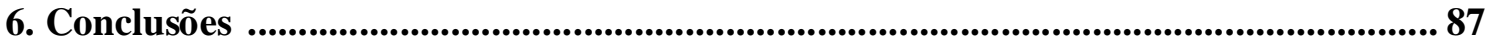

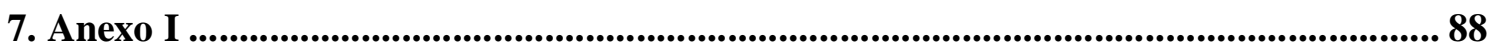

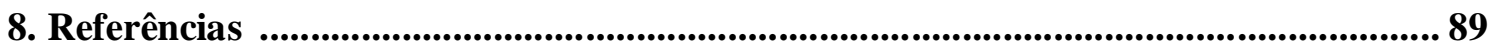




\section{Introdução}

\subsection{Variação e seleção}

Em seu livro a origem das espécies de 1859 Darwin explica a origem das diferentes espécies através da diferenciação de uma mesma espécie a partir dos fenômenos de variação e seleção. Cada individuo tem caraterísticas próprias com diferenças em maior ou menor grau que outros membros de sua espécie. Essa variação se dá em aspectos fisiológicos, anatômicos e comportamentais. Quando o ambiente é estável os indivíduos têm aproximadamente o mesmo grau de adaptação e as suas caraterísticas vão se manter em uma nova geração. Entretanto, se houver mudanças significativas no ambiente, àqueles indivíduos com caraterísticas favoráveis ao novo contexto terão maior chance de sobreviver, e passar tais características para gerações seguintes (DARWIN, 1992). Os eventos ambientais "selecionam" as caraterísticas, no sentido em que essas caraterísticas se apresentaram com maior frequência no futuro. A seleção natural é um fenômeno que ocorre ao longo de milhares de anos, entretanto as mudanças do comportamento podem ser observadas em pouco tempo. A reprodução com uma ampla diversidade de condições tornou-se possível com a evolução de dois processos pelos quais os organismos podem adquirir comportamentos apropriados aos novos ambientes: O comportamento respondente e operante. Modificar o ambiente e testar as possíveis respostas dos animais a uma mudança é uma forma de selecionar os seus comportamentos e de alguma maneira aumentar a frequência de alguma caraterística para poder estudar os mecanismos por trás dela (LEON ; CARDENAS, 2011).

\subsection{Vulnerabilidade ao estresse e transtornos associados}

Desenvolver uma psicopatologia depende de muitos fatores genéticos e ambientais. Embora o número de pessoas que sofrem de algum tipo de transtorno psiquiátrico, psicológico ou comportamental, como, por exemplo, a ansiedade, seja cada vez maior, o diagnóstico e o tratamento dessas pessoas possuem um número reduzido quando comparados com a população em geral. No caso da ansiedade nos Estados Unidos a prevalência é 0,9\% em adolescentes e 2,9\% em adultos (AMERICAN PSYCHIATRIC ASSOCIATION, 2013). Mostrando que mesmo compartilhando o mesmo ambiente e sendo submetidos aos mesmos 
estímulos, nem todas as pessoas têm a mesma sensibilidade (vulnerabilidade) em desenvolver psicopatologias.

Por exemplo, no desamparo aprendido, modelo animal clássico modificado para ratos, proposto por Seligman (1975) onde os animais recebem quarenta choques inescapáveis nas patas, de $10 \%$ a $60 \%$ dos ratos ficam desamparados (WIELAND et al., 1986; DRUGAN et al., 1989) mostrando assim que o mesmo estimulo não gera a mesma resposta comportamental nem fisiológica em todos os animais. Isto tem sido encontrado também em outros modelos (KOOLHAAS, 2008; LEON; LANDEIRA-FERNANDEZ; CARDENAS, 2009; KOOLHAAS et al., 2010).

A vulnerabilidade ou reatividade biológica a estressores psicológicos aciona um repertório de respostas centrais e periféricas (neuroendócrinas) complexas e integradas, para preparar o individuo aos desafios. Entretanto, a experiência e história de vida ajudam na modulação da resposta junto com a variação de genes transmissíveis. Assim, a adversidade precoce pode afetar o desenvolvimento dos sistemas que controlam o estresse, levando a um perfil de uma alta e prolongada reatividade.(CHARNEY, 2004).

As respostas de defesa a situações aversivas podem ser estudadas em diferentes espécies ao longo da escala evolutiva, pois são similares (DARWIN, 1872), mostrando o seu valor adaptativo e a possibilidade de estudar os seus mecanismos em outras espécies como em roedores, por exemplo, Rattus norvergicus.

$\mathrm{O}$ estresse tem sido estudado em muitas espécies principalmente mediante o estudo da liberação de hormônios, como os glicocorticoides, como sinalizadores. Recentemente Close et al. (2010) encontraram receptores específicos para glicocorticoides na "Lampréia de mar", uma das linhagens mais antigas de vertebrados. Também foi encontrado no plasma, 11deoxicortisol, um esteroide precursor de cortisol e corticosterona. Além disso, foi observado que a ativação por estresse tirando água das Lampréias aumenta a liberação do 11 deoxicortisol.

Contudo sabe-se que a resposta dos mamíferos ao estresse é um pouco mais complexa. Isto principalmente porque estão dotados de estruturas prosencefálicas (como o córtex préfrontal) e mesencefálicas (como a substância cinzenta periaquedutal; PAG) hierarquicamente superiores que controlam as respostas defensivas. Os mamíferos apresentam estados emocionais que, além de ter um componente fisiológico e comportamental, também possuem um componente cognitivo. 
A ansiedade pode ser definida como uma reação do sistema de defesa que gera um conjunto característico de alterações fisiológicas, perceptuais, cognitivas e comportamentais, em relação a situações ameaçadoras do meio ambiente (BRANDÃO, 2004; GROSS; HEN, 2004; INDOVINA et al., 2011). De acordo com o Manual Diagnóstico e Estatístico de Transtornos Mentais (DSM-IV-TR) é uma resposta antecipada a um perigo potencial associada à tensão muscular e aumento de vigilância (AMERICAN PSYCHIATRIC ASSOCIATION, 2013).

Existe como resposta adaptativa, e estudos propõem que, em determinadas intensidades, a ansiedade pode ser benéfica, podendo melhorar o desempenho do individuo em determinada tarefa, essa teoria é conhecida como a "teoria do U invertido" (YERKES; DODSON, 1908; TALLMAN et al., 1980; LANDGRAF; WIGGER, 2003; BENNINGHOVEN et al., 2006; LEE; WADSWORTH; HOTOPF, 2006; LANDGRAF et al., 2007; KUKOLJA et al., 2008). Entretanto, quando a ansiedade é experimentada durante um longo período de tempo (mais de seis meses de acordo com o DSM-V) ou de forma excessiva, os mecanismos ativados podem levar ao desenvolvimento de patologias, como ocorre nos transtornos de ansiedade (BRANDÃO, 2004; GROSS; HEN, 2004).

Existem diferentes formas de ansiedade patológica. Segundo o Manual Diagnóstico e Estatístico de Transtornos Mentais na sua quarta edição (DSM-IV-TR) a ansiedade patológica pode se classificar em 5 tipos: transtorno obsessivo compulsivo (TOC), fobias, transtorno de pânico, transtorno de estresse pós-traumático e transtorno de ansiedade generalizada (TAG). As expressões comportamentais desses distúrbios representam uma combinação de dimensões comportamentais influenciadas por fatores genéticos e ambientais. São condições crônicas que afetam a qualidade de vida, produtividade e em alguns casos começa nos inicios da vida, o que pode afetar o desenvolvimento social e pessoal (KHEIRBEK et al., 2012). No DSM-V foram incluídas o mutismo seletivo e a ansiedade por separação. Assim, também foi excluído o TOC.

O TAG se caracteriza por apresentar, como sintomas, a sensação de apreensão constante e de exagerada preocupação na ausência de um estímulo aversivo. Este transtorno pode ser desencadeado por experiências prévias ou não, e inclui respostas fisiológicas como sudorese, aumento da pressão sanguínea, fadiga, dentre outras (ASSOCIAÇÃO AMERICANA DE PSIQUIATRIA, 2002; BRANDÃO, 2004). Indivíduos com TAG têm uma exagerada reatividade aos estímulos neutros parecidos com o estimulo aversivo, que ocorre ainda na 
presença de estímulos que indicam segurança (KHEIRBEK et al., 2012). Em roedores existem diferentes padrões comportamentais e fisiológicos que indicam ansiedade tais como um menor limiar para detecção sensorial e uma maior taxa de congelamento (freezing), que corresponderia a um estado de imobilidade e alerta onde todos os movimentos cessam, com exceção daqueles necessários para a respiração (GODSIL; QUINN; FANSELOW, 2000; BURGHARDT et al., 2007).

Dependendo da ativação de substratos neurais específicos têm sido classificados pelo menos quatro tipos de congelamento dependendo da ativação de substratos neurais específicos (BRANDÃO et al., 2008). $1^{\circ}$. O congelamento induzido pela estimulação da coluna ventral da substância cinzenta periaquedutal (PAGv), correspondendo ao componente de defesa. $2^{\circ}$. A imobilidade na presença de um estímulo contextual ou sinalizado pareado com choques elétricos, correspondendo a um modelo de TAG. $3^{\circ}$. O congelamento induzido pela estimulação da porção dorsal da substância cinzenta periaquedutal (PAGd), obtido pela estimulação elétrica ou química da PAGd, capaz de produzir congelamento antes de produzir outros comportamentos, como galope utilizado como modelo de ataque de pânico. $4^{\circ}$. A resposta de congelamento pós-estimulação da PAGd, proposto como modelo de transtorno do pânico e correspondendo à duração da resposta de congelamento após a interrupção da estimulação elétrica da PAGd.

\subsection{Modelos teóricos de Ansiedade e Medo}

Pesquisas utilizando técnicas farmacológicas e de imunomarcação apontaram a existência de diferentes tipos de ativação de substratos neurais específicos dependendo da natureza do estimulo.

Um deles é o sistema que processa principalmente estímulos incondicionados, gerando as respostas inatas de defesa, como o ataque e a fuga como respostas incondicionadas. $\mathrm{O}$ denominado "Sistema Cerebral Aversivo" é composto pelo complexo amigdalóide, o hipotálamo medial, colículos superiores e inferiores e a PAGd (GRAEFF, 1981; GRAEFF, 1994; SILVEIRA et al., 2001; BRANDÃO, 2004).

Gray e McNaughton (2000) propuseram outro modelo teórico relacionado às reações de medo condicionadas, ou seja, as respostas associadas a estímulos que adquiriram, pelo pareamento sucessivo, propriedades aversivas. É o caso do medo condicionado contextual, 
onde o estimulo neutro "contexto" começa a ser catalogado como um estímulo aversivo pelo pareamento com o choque. Esse sistema, denominado de "Sistema de Inibição Comportamental" é composto por estruturas como o septo e o hipocampo, que atuariam avaliando e colocando um peso nas informações contextuais, de acordo com as informações prévias, gerando uma inibição comportamental (como o congelamento), aumentando a vigilância e a atenção, em resposta a estímulos aversivos condicionados (GRAY ; MCNAUGHTON, 2000; BRANDÃO, 2004). Os fármacos utilizados no tratamento do TAG diminuem a inibição comportamental e fazem com que o indivíduo consiga desempenhar suas atividades de forma normal; diminuindo a imobilidade e o nível de vigilância exagerada.

Por outro lado, Blanchard e Blanchard (1986) propuseram que os níveis de ameaça levam a padrões de respostas defensivas comportamentais diferentes. Assim, estímulos que sinalizam uma ameaça potencial, como contextos novos, levam a respostas de avaliação de risco, como levantamento (rearing) ou esticamento. Por outro lado estímulos distais, em um contexto que foi previamente associado com um estímulo aversivo, levam a respostas como o congelamento condicionado contextual. Por ultimo, estímulos proximais levam a respostas do tipo fuga ou luta (BLANCHARD; FLANNELLY; BLANCHARD, 1986).

McNaugthon e Corr (baseados no trabalho de Blanchard e Blanchard, 1986) propuseram que existe para as distâncias defensivas, descritas acima, uma ativação fisiológica diferencial. Assim, distâncias defensivas menores ativariam estruturas mais caudais (subcorticais como a PAGd), para produzir respostas ativas (p.e. comportamentos associados ao ataque de pânico luta ou fuga), em quanto distâncias defensivas maiores ativariam estruturas mais rostrais (corticais como o hipocampo) induzindo uma inibição comportamental (p.e. comportamentos associados com o TAG como o congelamento). Porém, a distância defensiva pode diferir em relação com a percepção de perigo do indivíduo, em situações perigosas a distância defensiva pode ser percebida diferente em diferentes indivíduos, por exemplo, indivíduos humanos mais corajosos uma pequena distância real será necessária para ter um comportamento defensivo (MCNAUGHTON; CORR, 2004).

\subsection{Respostas fisiológicas ao estresse}

Grandes esforços são conduzidos para entender os componentes psicobiológicos do estresse e as psicopatologias relacionadas, tais como os transtornos de ansiedade. Segundo Selye (1985) o estresse é uma ameaça potencial ou real à homeostase, ou qualquer tipo de 
estimulo que leve à ativação do eixo Hipotalamo- Pituitaria Adrenal (HPA) (SELYE, 1985), a fim de preparar o animal a lidar com as novas situações e desafios. Existem muitas criticas a esta definição levando em consideração que existem estímulos não aversivos que levam a ativação do eixo HPA (KOOLHAAS et al., 2011). Estes autores propõem que o termo estresse deva ser restringido às condições, nas quais as demandas ambientais excedem a capacidade regulatória do organismo, em situações ambientais onde o individuo não tem controle nem pode prever (KOOLHAAS et al., 2011).

As respostas fisiológicas às situações de estresse estão relacionadas com a atividade do sistema nervoso autônomo (SNA) e o eixo HPA. No estresse agudo, o SNA ativa a porção simpática e reestabelece a condição basal do sistema parassimpático. O eixo HPA é ativado no estresse agudo e crônico, mediando a síndrome de adaptação geral (BRANDÃO, 2004).

Os hormônios glicocorticoides são o produto final da ativação do eixo HPA (Figura 1). A sua produção e liberação depende da ativação do núcleo paraventricular do hipotálamo que recebe aferências de diferentes estruturas como a amígdala e o hipocampo e sintetiza o fator liberador de corticotrofina (CRF- Corticotropin-releasing factor). O CRF é liberado na glândula pituitária, que sintetiza e secreta o hormônio adrenocorticotrófico (ACTH). Assim, o ACTH liberado na corrente sanguínea chega às glândulas adrenais e estimula a produção e liberação de glicocorticoides (JANSEN et al., 1995). Os glicocorticoides têm um papel importante na regulação do comportamento ansioso (BREMNER et al., 2004; AISA et al., 2007; CHAMPAGNE et al., 2008). Devido a sua estrutura lipofílica eles podem cruzar facilmente a barreira hematoencefálica e entrar no encéfalo, onde influenciam varias respostas incluindo emoção e cognição (SANDI et al., 2003; SANDI; PINELO-NAVA, 2007). No caso do estresse agudo, os glicocorticoides podem estimular a mesma atividade adaptativa que o SNA. Mas em altas concentrações, decorrente da exposição crônica, podem ter efeitos perigosos para o indivíduo e desencadear doenças como a depressão e ansiedade (DE KLOET; KARST; JOELS, 2008). 


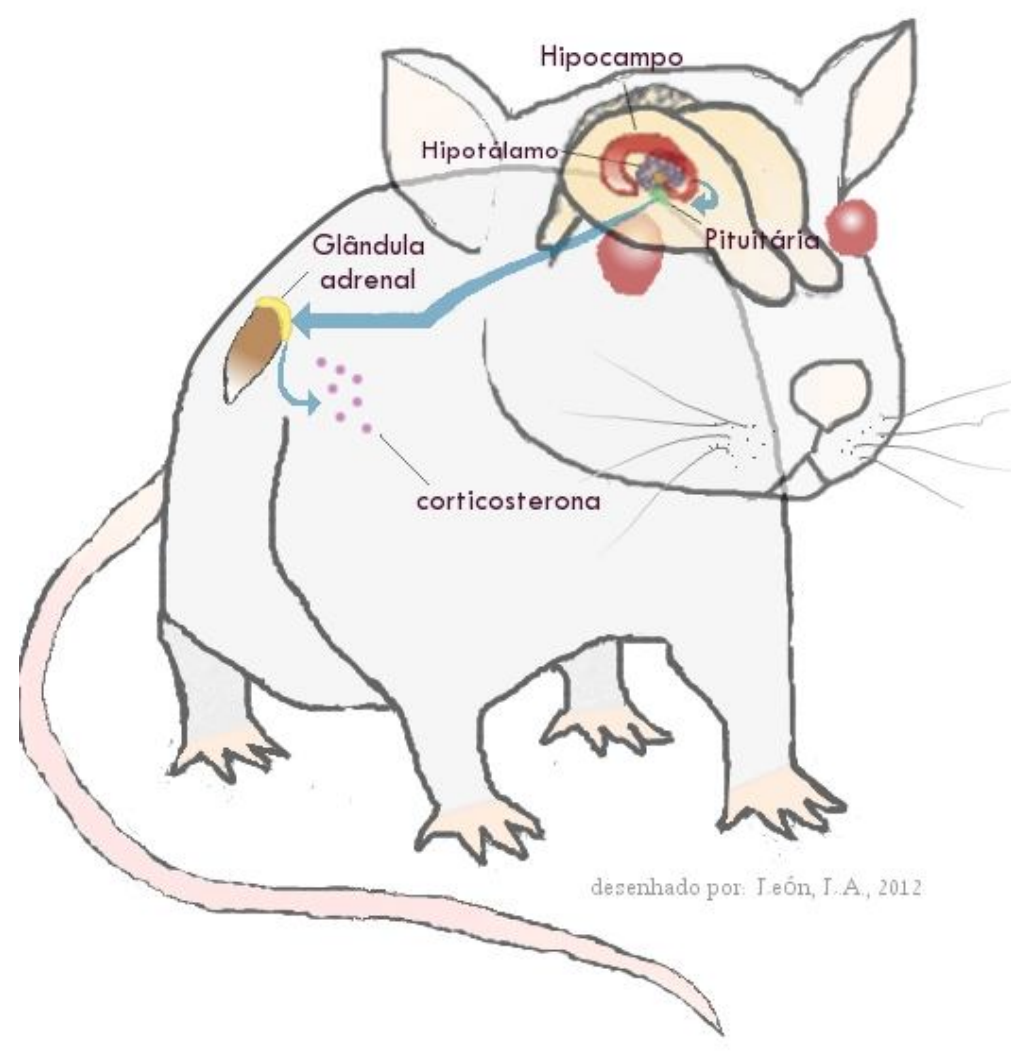

Figura 1. Estruturas como o hipocampo regulam a liberação do fator liberador de corticotrofina pelo Hipotálamo na glândula pituitária. A pituitária sintetiza e secreta o hormônio adrenocorticotrófico (ACTH) que estimula a produção e liberação dos glicocorticoides nas glândulas adrenais.

Os glicocorticoides atuam principalmente nos receptores mineralocorticoides (MR) e glicocorticoides (GR). A afinidade de ligação dos MR pelos glicocorticoides é 10 vezes maior que os GR (DE KLOET; KARST; JOELS, 2008), por isto os MR estão quase sempre ocupados pela secreção basal de corticoides. Os GR são ocupados quando ocorre um aumento na liberação deles, por exemplo, quando os animais estão sob estresse ou no pico do ritmo circadiano. O hipocampo é a estrutura que contem mais receptores MR e GR e assim é o principal alvo da atividade glicocorticoide no cérebro (DE KLOET; KARST; JOELS, 2008; OLIJSLAGERS et al., 2008; GROENEWEG et al., 2012).

Estudos com ratos têm demonstrado que o TAG provoca aumento nas concentrações de glicocorticoides (corticosterona no rato) plasmáticas (ADAMS et al., 2003; AGUILARVALLES et al., 2005; AISA et al., 2007; HEIM et al., 2008). Por outro lado, pesquisadores observaram que pacientes com transtorno de ansiedade têm o eixo HPA hiperativado, aumentando a liberação do CRF pelo hipotálamo. Isso faz com que a pituitária anterior secrete 
ACTH, hormônio que em níveis elevados, estimula o aumento da biossíntese e liberação de cortisol (principal hormônio glicocorticoide endógeno em humanos) (BUCHANAN et al., 2004; MARQUEZ; NADAL; ARMARIO, 2004; KUKOLJA et al., 2008).

Logo, os resultados obtidos em estudos com animais sugerem alguma correlação com seres humanos, demonstrando uma associação entre concentração de glicocorticoides altos no sangue e a resposta ao estresse (ALFAREZ; JOELS; KRUGERS, 2003; CHOY et al., 2008). Um exemplo disso é o efeito ansiogênico nos ratos testados no labirinto em cruz elevado (LCE) apos injeções intraperitoneais agudas e/ou crônicas de corticosterona (MITRA; SAPOLSKY, 2008). Esse hormônio também tem sido relacionado com a hiperatividade do hipocampo dorsal, inibindo a resposta adaptativa ao estresse (FILE; KENNY; CHEETA, 2000). Alguns estudos têm reportado que o aumento do estresse interfere nos processos de neurogênese hipocampal adulta, possivelmente por um efeito neurotóxico dos glicocorticoides e neurotransmissores como o glutamato (YU et al., 2004; WARNER-SCHMIDT; DUMAN, 2006).

\subsection{Proliferação celular e ansiedade}

O termo neurogênese pode levar a mal-entendidos, pois se pode referir a geração (gênesis) de novos neurônios ou de células neurais (i.e. neurônios e glia). No presente trabalho a proliferação celular de neurônios deve ser entendida como neurogênese. A neurogênese é um processo normal em estágios iniciais do desenvolvimento. Antigamente acreditava-se que nosso sistema nervoso central (SNC) era estático, feito de elementos não renováveis. Porém nos anos noventa foi mostrado que a neurogênese também é um mecanismo presente no cérebro adulto. Ocorre como um processo "constitutivo", pois a geração de novos neurônios é espontânea como parte de um processo homeostático/fisiológico (GOULD et al., 1997; GOULD et al., 1999a; GOULD et al., 1999b; JACOBS; VAN; GAGE, 2000; BALU; LUCKI, 2008).

Em mamíferos são reconhecidos principalmente dois "sítios neurogênicos": a zona subventricular (SVZ) e a zona subgranular do giro denteado do hipocampo (SGZ). O hipocampo, que é um componente central do sistema límbico, é um dos principais reguladores da expressão emocional. Sabe-se que o hipocampo está envolvido em respostas de adaptação (coping), que permitem reações adaptativas frente ao estresse. Sabe-se também que esta resposta é facilitada pelo aumento da liberação de 5-HT no hipocampo dorsal (JOCA; 
PADOVAN; GUIMARAES, 2003). Os neurônios que se integram na camada granular do giro denteado do hipocampo proliferam na SGZ. No mesmo sentido esses neurônios diferenciamse e fazem conexões funcionais e esse processo tem uma duração de duas a quatro semanas (KEMPERMANN; VAN; GAGE, 2000; VAN et al., 2002; BROWN et al., 2003; LAPLAGNE et al., 2006; SAXE et al., 2006).

A neurogênese se origina em camadas germinais que contem células tronco/progenitoras com um ambiente celular adequado para o desenvolvimento das novas células. A gliogênese (produção de células gliais) é um processo que ocorre em todo o SNC. A oligondendroglia é a célula que mais prolifera no estagio adulto e são os astrocitos os que proliferam em menor quantidade. A diminuição das habilidades neurogênicas ocorre em paralelo com uma restrição de ambientes adequados de células-tronco derivados da camada germinal, assim a proliferação de células-tronco adultas ou progenitoras, diferenciação, sobrevivência, maturação e integração dos novos neurônios podem ser reguladas por diversas atividades fisiológicas e patológicas (ZHAO et al., 2006; ZHAO et al., 2008). Dentre os processos patofisiológicos que influenciam a neurogênese, o estresse e a ansiedade são possíveis mediadores da diminuição significativa da taxa de proliferação celular e diferenciação de novos neurônios na SGZ (COE et al., 2003; BAIN; DWYER; RUSAK, 2004; AZTIRIA et al., 2007; CASTRO et al., 2010). Lee et al (2006) submeteram ratos Sprague-Dawley a um protocolo de estresse crônico variado (MCS- mild chronic stress) de 19 dias e injetaram 5bromo-2-deoxiuridina (BrdU) o marcador de neurogênese mais utilizado, análogo da base nitrogenada timina que se incorpora ao DNA durante a fase-S do ciclo celular (GRATZNER et al., 1978; KEE et al., 2002), antes ou depois do MCS para avaliar a proliferação e a sobrevivência/diferenciação das novas células. Assim, foi observado que o MCS diminuiu significativamente a sobrevivência de células novas, mas não afetou a proliferação (LEE et al., 2006). As experiências aversivas precoces também alteram a neurogênese adulta em resposta ao estresse como foi reportado por Mirescu, Peters e Gould (2004).

O BrdU, conforme aos estudos previamente citados, deve ser injetado intraperitonealmente (i.p.), no animal antes do experimento para que ocorra sua incorporação. Na Figura 2. explica-se a incorporação do BrdU no ciclo celular. Após isso, o BrdU pode ser detectado por imuno-histoquímica após a fixação do tecido. O BrdU é muito utilizado, pois permanece nas células que se dividiram e nas suas células filhas. Isto é útil, pois permite rastrear a linhagem da célula e sua sobrevivência. Outro marcador útil para avaliar a 
proliferação é o Ki-67 uma proteína que está presente no núcleo de células em divisão, durante as fases G1, S e G2 (SCHOLZEN; GERDES, 2000; KEE et al., 2002). Assim, como BrdU, a expressão dessa proteína pode ser verificada por imuno-histoquímica e apresenta maior taxa de células marcadas em comparação ao BrdU, por ser expressa na célula durante um período maior, do que aquele onde ocorre a incorporação do BrdU (KEE et al., 2002).

Para marcação de neurônios recém-diferenciados alguns marcadores endógenos podem ser utilizados. A proteína doublecortina (DCX) é um marcador utilizado para neurônios imaturos. DCX é uma fosfoproteína associada aos microtúbulos, expressa durante a migração e diferenciação de neurônios podendo ser utilizada no estudo da árvore dendrítica (RAO; HATTIANGADY; SHETTY, 2008), bem como na morfologia desses neurônios (ARISI; GARCIA-CAIRASCO, 2007).

Lemaire et al (1999) reportaram que diferenças individuais na resposta à novidade correlaciona com a proliferação celular no GD sugerindo uma relação entre comportamentos associados à ansiedade e à neurogênese. Por tanto, é possível supor que ratos com altos níveis basais de estresse possam apresentar uma proliferação celular hipocampal diminuída e que essa possa ser a causa da ausência de estratégias de adaptação, assim como da sua susceptibilidade para desenvolver ansiedade.

Alguns estudos post mortem têm revelado atrofias ou morte neuronal no córtex préfrontal e no hipocampo (KARTEN; OLARIU; CAMERON, 2005) 


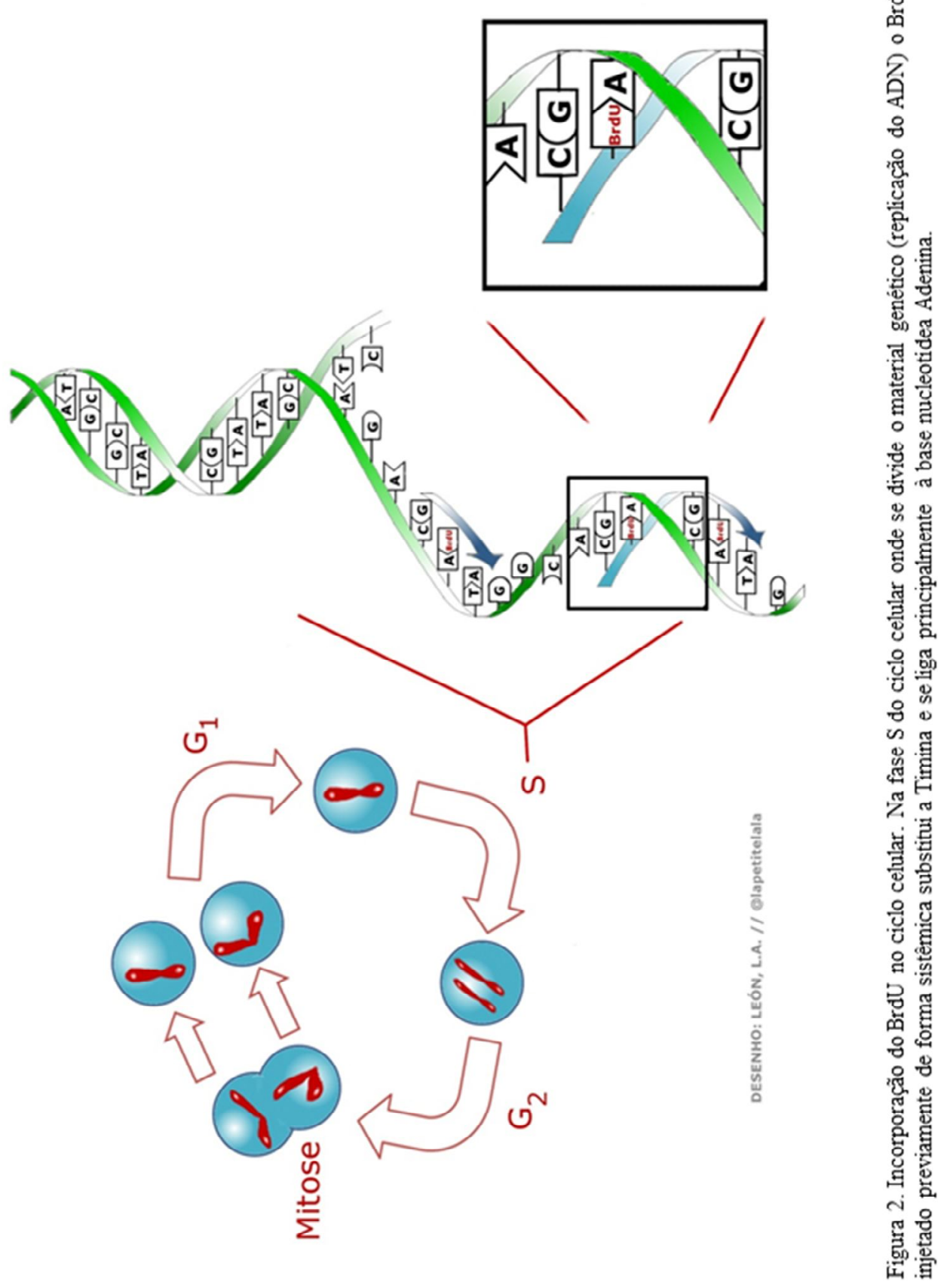




\subsection{Atividade neuronal e ansiedade}

Estudos de mudanças na atividade neuronal, que utilizam técnicas como a expressão da proteína Fos, são úteis na determinação de estruturas envolvidas e mapeamento neuroanatômico, dos circuitos neurais subjacentes às respostas comportamentais, autonômicas e neuroendócrinas (MENARD; CHAMPAGNE; MEANEY, 2004; BORELLI, 2006). A estimulação dos neurônios, como mostrado na Figura 3, leva à despolarização, ativando cascatas de sinalização nos mesmos. Tal fato leva à ativação de mensageiros secundários que podem ativar a produção de fatores de transcrição, que iniciam a transcrição e/ ou a repressão de outros genes (HERDEGEN; LEAH, 1998). Assim, a atividade neuronal é responsável por induzir alterações na expressão genica da célula pós-sináptica. Os neurotransmissores que se ligam a receptores e fatores de crescimento iniciam uma serie de cascatas que ativam fatores de transcrição. Esses fatores de transcrição, como o CREB, induzem os genes de expressão imediata.

A Fos é uma proteína utilizada como marcador da atividade neuronal codificada pelo proto-oncogene c-fos que pertence aos genes de ativação imediata. A Fos ativa a transcrição de genes envolvidos nos processos de proliferação, diferenciação e sobrevivência celular para evitar o dano celular. Os proto-oncogenes produzem uma alteração na função celular modificando a atividade das proteínas (DRAGUNOW; PETERSON; ROBERTSON, 1987; SAGAR; SHARP; CURRAN, 1988).

A expressão de Fos oferece uma resolução celular, pois se encontra no núcleo dos neurônios em circunstancias normais e patológicas. Isto é uma vantagem sobre o método de 2deoxiglicose que mensura a atividade metabólica, mas não distingue o metabolismo alterado da glucose do corpo neuronal e suas fibras aferentes (SAGAR; SHARP; CURRAN, 1988). O RNA mensageiro (RNAm) do c-fos e a proteína Fos são encontrados em baixas concentrações no SNC. Porém o aumento da expressão rápida e transitória se da como resposta a estímulos fisiológicos ou nocivos, à ação de hormônios, à ligação de neurotransmissores aos seus receptores e à despolarização da membrana neuronal. Podem ser detectados por técnicas como a hibridação in situ e imuno-histoquímica (SAGAR; SHARP; CURRAN, 1988; DONAHOE ; DORSEL, 1997; ALBRECHET, 2010). 


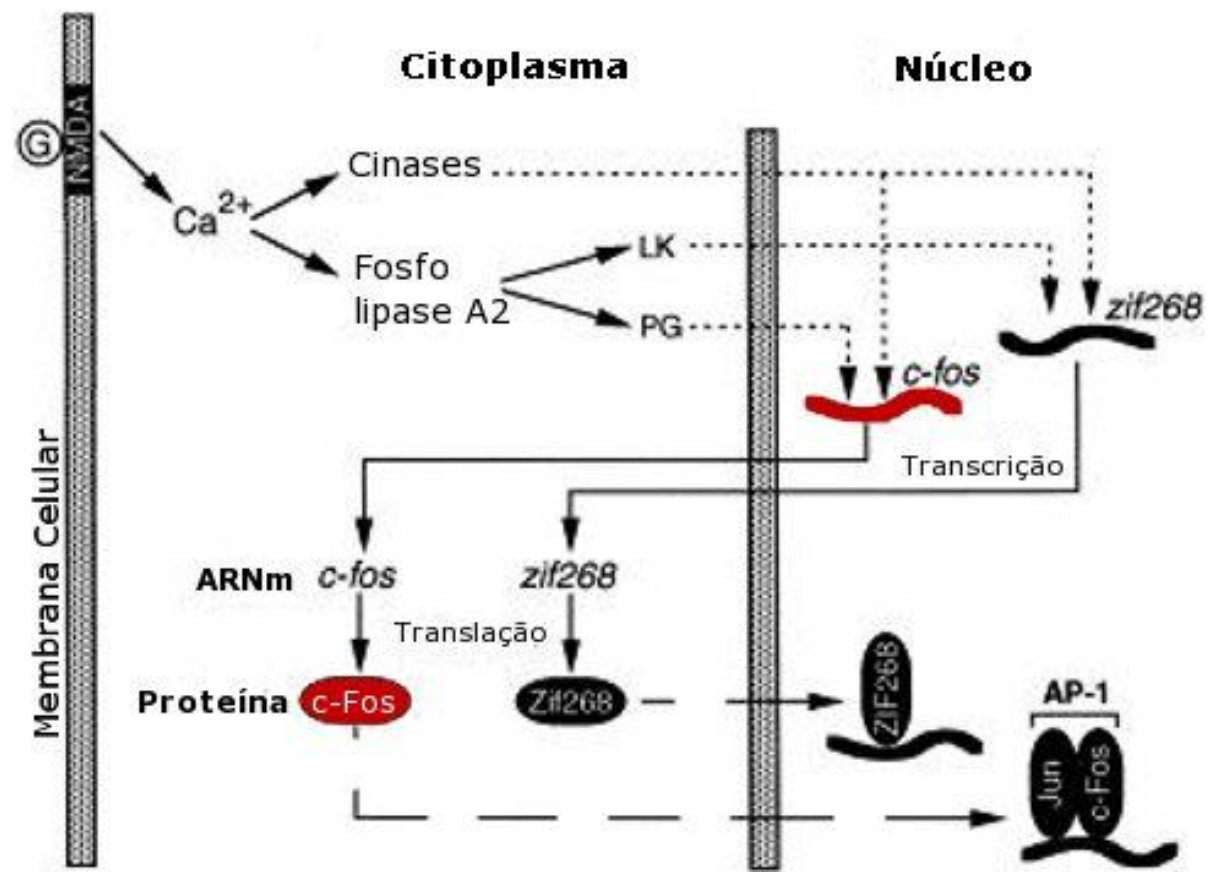

Figura 3. Via de indução do c-fos. No exemplo se da por meio da ativação do receptor NMDA pelo Glutamato $(\mathrm{G})$. $\mathrm{O}$ influxo de $\mathrm{Ca}^{2+}$ inicia a cascata de eventos que são guiadas pelas enzimas efetoras (Cinases, fosfolipasa A2). Isto leva a um incremento na transcrição do c-fos que induz a expressão da proteína c-Fos (Traduzido e adaptado de Kaczmarek (1999)).

\subsection{Serotonina e ansiedade}

Historicamente, os sistemas de neurotransmissão mais amplamente investigados no campo da neurofisiologia do medo e da ansiedade têm sido os sistemas gabaérgico e o serotoninérgico (5-HT). Neste sentido, os primeiros fármacos utilizados em pacientes com transtornos de ansiedade atuavam na modulação do sistema gabaérgico (TREIT, 1984). Atualmente, entretanto, cada vez mais a primeira escolha para o tratamento destes transtornos têm sido os compostos que atuam principalmente sobre o sistema serotoninérgico. Isto se deve, principalmente pela crescente eficácia destes compostos em relação àqueles que atuam no sistema gabaérgico (DURANT, 2009). Além disso, muitas evidências sugerem que os fármacos que atuam na serotonina produzem menos efeitos secundários e favorecem, em alguns casos, a plasticidade, muito importante para uma psicoterapia adequada. Por exemplo, o tratamento crônico com o inibidor seletivo da recaptação de serotonina (ISRS), fluoxetina, 
aumenta a neurogênese adulta no hipocampo e aumenta a produção de BDNF (Brain-derived neurotrophic factor), uma proteína importante no suporte e sobrevivência dos neurônios.

De fato, evidências farmacológicas e comportamentais indicam fortemente que os neurônios serotonérgicos possam estar diretamente envolvidos na modulação das reações de ansiedade. As primeiras evidências dessa relação foram obtidas na década de 60 . Robichaud e Sleddge (1969) observaram que a administração sistêmica de para-clorofenilalanina (p-CPA; inibidor da síntese de 5-HT) em ratos, facilitava a expressão dos comportamentos de esquiva, em animais submetidos ao modelo de esquiva ativa. Esse efeito, também testado por Geller e Blum (1970), foi bloqueado pela administração de 5-hidroxitriptofano (5-HTP, precursor da síntese de 5-HT) também em ratos, mostrando um efeito ansiolítico pela diminuição da disponibilidade de 5-HT. .

Outra importante evidência é que os benzodiazepínicos (fármacos amplamente utilizados no tratamento de transtornos de ansiedade) diminuem, como efeito secundário, os níveis de 5HT. Wise e colaboradores (1972) mostraram que os efeitos comportamentais dos ansiolíticos tradicionais (benzodiazepínicos) podiam ser mimetizados por um antagonista serotoninérgico (metisergida) e por p-CPA, em ratos submetidos ao teste de conflito de Geller e Seifter. Mais ainda, eles mostraram que uma injeção intracerebroventricular de $\left[{ }^{14} \mathrm{C}\right]$ serotonina ou $\left[{ }^{3} \mathrm{H}\right]$ norepinefrina era capaz de bloquear os efeitos ansiolíticos do benzodiazepínico oxazepam. Estes resultados apoiam a hipótese de que o aumento da serotonina está associado com o aumento da ansiedade e que o efeito ansiolítico depende do turnover da serotonina causada pelos benzodiazepínicos.

Outros fármacos que interagem com o sistema serotoninérgico com potencial ansiolítico também fortalecem tal hipótese. Por exemplo, a administração de inibidores seletivos da recaptação de 5-HT, tais como a fluoxetina, aumentam a ansiedade quando aplicados de forma aguda em altas doses em humanos e ratos. Porém quando a administração é crônica, o efeito ansiogênico é substituído por efeito antiaversivo e antidepressivo. Por outro lado, agonistas parciais dos receptores inibitórios 5- $\mathrm{HT}_{1 \mathrm{~A}}$ (como a Buspirona), antagonistas de receptores do tipo 5- $\mathrm{HT}_{2}$ (como a Ritanserina) e 5- $\mathrm{HT}_{3}$ (como o BRL 46470A) promovem efeitos ansiolíticos em animais submetidos a vários testes de ansiedade, como o LCE (CRITCHLEY; HANDLEY, 1987; BROEKKAMP et al., 1989; ANDREWS; FILE, 1993; GRAEFF et al., 1996; GARGIULO et al., 1996; BECKER; HAMON; BENOLIEL, 1999). 
A teoria clássica da serotonina na explicação da ansiedade foi baseada neste conjunto de evidências. Em geral, a teoria diz que a redução da neurotransmissão serotonérgica diminui a ansiedade, enquanto que a sua estimulação induz um efeito ansiogênico (CHOPIN; BRILEY, 1987; CRITCHLEY; HANDLEY, 1987).

Porém, anos mais tarde alguns pesquisadores, observaram algumas inconsistências com relação à teoria clássica da serotonina (DEAKIN, 1991; GRAEFF et al., 1996; GRAEFF; VIANA; MORA, 1997). Estudos com injeções intracerebrais em roedores mostraram que, embora a estimulação elétrica da substância cinzenta periaquedutal dorsal (PAGd- dorsal periaqueductal grey matter) possa induzir um efeito aversivo (comportamentos tipo ataque de pânico) a aplicação local de 5-HT pode produzir efeitos ansiolíticos como o aumento do limiar elétrico necessário para induzir as reações de pânico (SCHUTZ; DE AGUIAR; GRAEFF, 1985). Isto pode ser explicado pelo efeito inibitório que a 5-HT tem especificamente nesta área do cérebro. Neste sentido Deakin e Graeff (1991) propuseram a teoria dual da serotonina. Segundo esta visão, a serotonina teria um papel dual na modulação das respostas defensivas e nas reações de ansiedade. Se por um lado o aumento da serotonina na porção mais anterior do cérebro está associado com um aumento de comportamentos de ansiedade, por outro, o aumento deste mesmo neurotransmissor em porções mais posteriores do cérebro (como a PAG) é capaz de inibir respostas defensivas associadas com o transtorno de pânico.

Estas evidências sugerem fortemente que os diferentes efeitos antiaversivos ou aversivos podem ser mais bem explicados não pela quantidade, mas sim pela interação da serotonina com os seus receptores. É importante lembrar que existem pelo menos 7 famílias de receptores de 5-HT, que apresentam funções diferentes dependendo da sua expressão e localização. Os receptores mais estudados na fisiopatologia dos transtornos de ansiedade são os $5-\mathrm{HT}_{1 \mathrm{~A}}$ e $5 \mathrm{HT}_{2 \mathrm{~A}}$. No presente trabalho abordaremos os $5-\mathrm{HT}_{2 \mathrm{~A}}$.

\subsubsection{Receptores $5-H T_{2 \mathrm{~A}}$ e ansiedade}

Os receptores $5-\mathrm{HT}_{2 \mathrm{~A}}$ pertencem à família de receptores $5-\mathrm{HT}_{2}$, composta pelos receptores $5-\mathrm{HT}_{2 \mathrm{~A}}$, que corresponde ao $5-\mathrm{HT}_{2}$ ou $\mathrm{S} 2$ da nomenclatura clássica, $5-\mathrm{HT}_{2 \mathrm{~B}}$ que 
corresponde ao tipo 5- $\mathrm{HT}_{2}$ e se encontra no estomago, e o 5- $\mathrm{HT}_{2 \mathrm{C}}$ antigamente conhecido como o 5-HT $1 \mathrm{C}$ (HUMPHREY; HARTIG; HOYER, 1993; HOYER et al., 1994). São todos metabotrópicos associados à proteína $\mathrm{Gq}$ associada à via sinalizadora do inositol fosfato (EGAN et al., 1998). A maior concentração de sítios de ligação do receptor 5-HT $2 \mathrm{~A}$ são áreas corticais frontais, mas também tem sido observada uma alta concentração em áreas dopaminérgicas com um $\mathrm{K}_{\mathrm{D}}$ maior no núcleo accumbens, o que indicaria uma menor afinidade (LEYSEN et al., 1982; APPEL et al., 1990). O padrão de distribuição sugere que a ativação desses receptores estaria envolvida com a regulação dos transtornos do humor (DHONNCHADHA; BOURIN; HASCOET, 2003).

Diferentes pesquisas têm relacionado os $5-\mathrm{HT}_{2 \mathrm{~A}}$ com o efeito antidepressivo e ansiolítico observado com o tratamento com antidepressivos que aumentam a disponibilidade da 5-HT na fenda sináptica. Inclusive tem sido observado que a eficácia na melhora dos pacientes com transtorno obsessivo compulsivo é favorecida com o tratamento conjunto com um antagonista de $5-\mathrm{HT}_{2 \mathrm{~A}}$. Preconiza-se que esse efeito é devido ao processo de downregulation que ocorre após o tratamento com agonistas e antagonistas do receptor 5-HT $2 \mathrm{~A}$ (BERENDSEN; BROEKKAMP, 1991; MCDOUGLE et al., 2000; SZABO; BLIER, 2002; MAREK et al., 2003; DHONNCHADHA et al., 2005). Dhonnchadha et al (2005) mostraram que o antagonista do receptor $5-\mathrm{HT}_{2 \mathrm{~A}}$, SR $46349 \mathrm{~B}$, bloqueou o efeito antiaversivo da paroxetina (ISRS mais efetivo) no teste das quatro placas (FPT- four plate test) em camundongos. Foi observado também que a coadministração de paroxetina com o 1-[2,5-dimetoxi-4-iodofenil]2-aminopropano (DOI; agonista preferencial de $5 \mathrm{HT}_{2 \mathrm{~A}}$ ) potencializa o comportamento punido nos camundongos tratados que foram submetidos ao mesmo modelo, mas não de forma significativa comparado com os que receberam só paroxetina (DHONNCHADHA et al., 2005). Assim, o tratamento conjunto de ISRS com agonistas do receptor 5-HT $2 \mathrm{~A}$ parecem ser bom para a ansiedade. Porém o papel do receptor $5-\mathrm{HT}_{2 \mathrm{~A}}$ no efeito ansiolítico continua sendo ambíguo.

Sabe-se que a neurotransmissão excessiva mediada por receptores $5-\mathrm{HT}_{2}$ aumentam os sintomas associados com a ansiedade e a depressão como o suicídio (STANLEY; MANN, 1983). Porém estudos feitos com animais não humanos mostraram que, a estimulação dos receptores 5- $\mathrm{HT}_{2 \mathrm{~A}}$, não gera um efeito do tipo ansiogênico. Por exemplo, no estudo feito por Dhonnchadha et al. (2003) no qual o objetivo foi avaliar diferentes compostos associados aos receptores 5- $\mathrm{HT}_{2}$ em camundongos submetidos a modelos de ansiedade, como o LCE, o 
paradigma de claro/escuro e o FPT, eles encontraram que nenhum dos agonistas, DOI (agonista preferencial de $5 \mathrm{HT}_{2 \mathrm{~A}}$ ), BW723C86 (agonista seletivo de 5 $\mathrm{HT}_{2 \mathrm{~B}}$ ) e RO 60-0175 (agonista seletivo de 5- $\mathrm{HT}_{2 \mathrm{C}}$ ), apresentaram um perfil ansiogênico nos ratos. Por outro lado, a administração de ketanserina induziu um efeito ansiolítico no LCE em doses baixas (0,015 e $0,03 \mathrm{mg} / \mathrm{Kg}$ ), enquanto que doses altas ( 1 e $2 \mathrm{mg} / \mathrm{Kg}$ ) diminuíram a frequência de entradas dos ratos aos braços abertos e fechados. Em contraste, foram observados efeitos ansiolíticos com a aplicação de agonistas de receptores $5 \mathrm{HT}_{2 \mathrm{~A} / 2 \mathrm{~B}}$ no aumento do comportamento punido dos camundongos submetidos ao FPT (DHONNCHADHA; BOURIN; HASCOET, 2003).

Contudo, as diferenças nos resultados dependem dos modelos utilizados para medir os comportamentos ansiosos, por exemplo, se as tarefas são incondicionadas como no caso do LCE ou condicionadas como no caso do FPT, e dos diferentes tipos de transtornos de ansiedade que modelam (por exemplo, transtorno de ansiedade generalizada, pânico, etc.) que se caracterizam por ativar vias diferentes. Também das vias de administração dos fármacos e das doses utilizadas. Existem outros estudos com resultados paradoxais e bifásicos para alguns fármacos que atuam sobre receptores $5-\mathrm{HT}_{2}$.

O fármaco ketanserina é um agonista preferencial $(\mathrm{Ki}=2-4 \mathrm{nM})$ com alta afinidade de ligação ao receptor 5- $\mathrm{HT}_{2 \mathrm{~A}}$. Não tem afinidade por nenhum receptor da família $5 \mathrm{HT}_{1}$ embora tenha uma afinidade media pelo5- $\mathrm{HT}_{2 \mathrm{C}}(\mathrm{Ki}=90-168 \mathrm{nM})$ (GRIEBEL, 1995; BRYANT et al., 1996).

Alguns estudos mostram o efeito ansiolítico de ketanserina e alguns não reportam nenhum efeito. Entretanto estas diferenças podem advir do uso de diferentes espécies, diferentes paradigmas de comportamento e principalmente pela dosagem utilizada. Por exemplo, Motta et al. (1992) avaliaram o bloqueio dos receptores $5-\mathrm{HT}_{2}$ no comportamento exploratório em ratos submetidos ao modelo do LCE, e encontraram que a ketanserina, induziu efeitos bifásicos. A menor dose $(0,5 \mathrm{mg} / \mathrm{Kg})$ diminuiu a aversão dos ratos aos braços abertos (maior número de entradas a braços abertos), um efeito ansiolítico. Na maior dose (1 $\mathrm{mg} / \mathrm{Kg}$ ) foi observada uma diminuição inespecífica da atividade locomotora total. Também no LCE Critchley e Handley (1987) mostraram que a ketanserina, nas doses de 0,1-1,0 mg/Kg, aumentou o número de entradas aos braços abertos, tendo um efeito ansiolítico, sendo a dose mais efetiva a de $0,5 \mathrm{mg} / \mathrm{Kg}$. No mesmo modelo Zangrossi e Graeff (1994) injetaram ketanserina na amigdala basolateral de ratos (1 and $10 \mathrm{nmol})$ e observaram uma diminuição nas entradas aos braços abertos, tendo por tanto, nessa área um efeito ansiogênico. 
Um estudo reportado por Griebel (1995) mostrou que a administração oral de uma dose de $10 \mathrm{mg} / \mathrm{Kg}$ de ketanserina, teve um efeito ansiogênico no teste de conflito Geller-Seifter, onde é punido o comportamento de pressionar a barra para obter comida. Porém, Witkin e Perez (1989-1990) injetaram ketanserina ip (0,3-3,0) em ratos Sprague-Dawley, submetidos ao mesmo teste de conflito e não observaram diferenças com respeito aos ratos controle.

Kennet et al (1989) e Kennet (1992) administraram doses subcutâneas de ketanserina $(0,2-1 \mathrm{mg} / \mathrm{Kg})$ em ratos Sprague- Dawley submetidos ao teste de interação social e não encontraram diferenças em comparação com aqueles que receberam veículo. Doses intraperitoneais maiores que $0,9 \mathrm{mg} / \mathrm{Kg}$ sempre têm sido reportadas como causadores de um efeito de diminuição da locomoção (MOTTA et al., 1992; HANDLEY et al., 1993)

Em modelos de pânico Jenck et al (1989) reportaram um efeito panicolítico em ratos que foram estimulados na substância cinzenta periaquedutal dorsal nas doses de ketanserina maiores que $1 \mathrm{mg} / \mathrm{Kg}$, mas como eles não fizeram uma avaliação da locomoção pode ser que o aumento no limiar de respostas afetivas fosse na verdade um problema de locomoção. No mesmo modelo quando injetada localmente na PAGd não foram observadas diferenças na resposta de pânico (SCHUTZ; DE AGUIAR; GRAEFF, 1985)

\subsection{A seleção da vulnerabilidade}

Deve ser entendido que a ansiedade é um fenômeno complexo, que depende tanto da vulnerabilidade do individuo para experimentar estados que podem ser interpretados por ele como ansiosos, assim como do traço de personalidade ansiosa. A ansiedade-estado é a experiência temporária desconfortável que ocorre quando o individuo se sente ameaçado por uma situação, e tem sido proposta como parte da explicação da variabilidade em testes de aprendizagem e memória (RIBEIRO et al., 1999; DE QUERVAIN et al., 2003). Por outro lado, o traço de ansiedade é o potencial ou a tendência a experimentar o estado de ansiedade (OHL, 2005).

O desenvolvimento de linhagens de ratos caracterizadas por altos ou baixos níveis de expressão emocional tem sido utilizado para investigar como os genes influenciam fenótipos de ansiedade (PELLOW, 1986; BADIA-ELDER et al., 2003; LANDGRAF; WIGGER, 2003; TOUYAROT; VENERO; SANDI, 2004). Edward C. Tolman, juntamente com o seu aluno 
Robert Tryon, foram os primeiros a selecionarem ratos pela capacidade de aprendizagem. Mas foi só em 1938 quando Calvin Hall em 1938 iniciou a primeira linhagem de ratos selecionados pela expressão emocional apresentada no teste campo aberto (para revisão ver ARCHER, 1973). A resposta emocional pode ser avaliada em diferentes testes que medem o componente inato como, por exemplo, quando o animal é colocado em um ambiente novo ou a resposta em situações de condicionamento (ex. medo condicionado).

Para o estudo da ansiedade, são utilizados modelos tanto em camundongos quanto em ratos (SALOME et al., 2004; MUIGG et al., 2007; VEENEMA et al., 2007; MALLO et al., 2008). Por exemplo, Overstreet et al. (1994), utilizando o método de isolamento fenotípico, separaram ratos com alta e baixa sensibilidade à resposta hipotérmica ao agonista de receptor 5-HT ${ }_{1 \mathrm{~A}}, 8$-hidroxi-2-di-N-propilamino-tetralina (8-OH-DPAT) (OVERSTREET et al., 1994). Da mesma forma, Salomé et al. (2004) utilizaram o LCE para separar ratos Wistar em duas linhagens, uma delas com uma alta resposta de ansiedade e a outra com baixa. A análise da expressão da proteína c-Fos em algumas áreas do encéfalo desses ratos demonstrou a existência de diferenças entre as linhagens em algumas regiões do circuito do medoansiedade, entre elas o hipotálamo e o córtex cingulado (Cg) (SALOME et al., 2004). Assim, o desenvolvimento de linhagens com características próprias, por separação fenotípica, por exemplo, pode ser utilizado como ferramenta no estudo das características comportamentais e neuroquímicas dos transtornos psiquiátricos, que envolvam alterações comportamentais.

Neste sentido, a seleção fenotípica, é uma ferramenta muito útil para trabalhar com populações vulneráveis ao estresse que sejam capazes de ilustrar melhor os substratos neurais dos transtornos de ansiedade. O presente trabalho apresenta resultados de duas linhagens de ratos obtidas, por pesquisadores do laboratório do professor Jesus Landeira Fernandez (na Pontifícia Universidade Católica do Rio de Janeiro, PUC-RJ) a partir da linhagem Wistar, por isolamento fenotípico da resposta ao modelo de medo condicionado. Estas foram denominadas "Carioca High Conditioned-Freezing" (Carioca Alto congelamento condicionado, CHF) e "Carioca Low Conditioned-Freezing" (Carioca Baixo congelamento condicionado, CLF). Além é utilizada uma linhagem Wistar controle, criada, fenotipada e submetida aos mesmos procedimentos das outras linhagens porém são submetidas a cruzamento randómico (RND). (GOMES; LANDEIRA-FERNANDEZ, 2008).

O teste do medo condicionado ao contexto é um procedimento experimental, amplamente utilizado no estudo da ansiedade e a memória emocional. No procedimento um estímulo neutro/condicionado (CS; contexto), se apresenta junto de um estimulo aversivo incondicionado (US), como um choque. Dependendo do protocolo experimental escolhido, 
depois dos pareamentos repetidos o CS começa a produzir respostas emocionais condicionadas na presença única do CS, como a supressão de respostas operantes, comportamento de freezing (BRANDÃO et al., 2008; GOMES; LANDEIRA-FERNANDEZ, 2008), mudanças na atividade autonômica (RESSTEL et al., 2008; GOMES et al., 2012) e facilitação da ação reflexa (PHILLIPS; LEDOUX, 1994). Este modelo tem sido utilizado na avaliação de efeitos de drogas utilizadas para o tratamento da ansiedade generalizada e o estresse pós-traumático (PSTD, Postraumatic Stress Disorder). A circuitaria neuronatômica associada com o medo condicionado ao contexto inclui como estruturas principais o hipocampo e a amigdala e suas conexões com a PAG (FANSELOW, 2010).

Depois das primeiras três gerações os ratos CHF apresentaram uma alta propensão a apresentar a resposta condicionada ao contexto de freezing quando comparados com os CLF e os controles. No presente trabalho os experimentos foram feitos com ratos das gerações 10 , 11,12 e 13.

Além disso, a linhagem de ratos CHF tem sido testada em modelos que avaliam aspectos cognitivos e emocionais. No que se refere a modelos animais de ansiedade, a linhagem CHF foi testada no LCE e no teste de interação social, tendo sido observado um elevado índice de ansiedade nesses animais, em relação aos ratos controle (Wistar), sem evidências de alterações locomotoras. Em modelos que avaliam depressão e memória, os animais CHF não mostraram diferenças significativas comportamentais com a linhagem controle no teste do nado forçado e no teste de reconhecimento de objetos (DIAS et al., 2009).

A mesma linhagem foi analisada histologicamente marcando 4, 6-diamidino-2-fenilindol (DAPI), corante fluorescente que se liga ao DNA e marca o núcleo celular, mostrando que não existem diferenças quantitativas ou qualitativas nas células do hipocampo dorsal no giro denteado (CA1- CA3) (DIAS et al., 2009).

Os dados obtidos até agora com os ratos CHF e CLF são importantes para o estudo da vulnerabilidade ao estresse e, portanto a vulnerabilidade a desenvolver psicopatologias como o TAG.

Trabalhos paralelos de outros com a linhagem CHF visam caracterizar esses animais em condições onde os ratos não são submetidos a nenhum tipo de estress (naive), enquanto neste estudo queremos estudar ratos que possuem a vulnerabilidade e são submetidos a estímulos aversivos, levando em conta que eles não apresentam, por exemplo, um congelamento espontâneo, mas precisam do estimulo aversivo para apresentar o comportamento ansioso. 
Assim como nos humanos, muitos animais podem apresentar a vulnerabilidade, mas nem todos apresentam a patologia, isso depende de como respondem ao estresse e as estratégias que se utilizam. Então além do interesse em estudar a neurobiologia subjacente da vulnerabilidade, nós estamos interessados em estudar a resposta ao estresse de animais vulneráveis. 


\section{Objetivos}

O objetivo geral do presente trabalho foi o de avaliar características fisiológicas subjacentes ao comportamento diferencial na resposta ao estresse.

Para isso foram utilizados ratos Carioca alto e baixo congelamento (CHF: Carioca High Conditioned Freezing e CLF: Carioca Low Conditioned-Freezing) e RDN, que foram selecionados pelo comportamento de congelamento condicionado a estímulos contextuais previamente associados a choques elétricos nas patas, tal como foi explicado no apartado 1.8.

\subsection{Objetivos Específicos}

(1) Mensurar a concentração de corticosterona plasmática, antes e depois da apresentação de uma situação aversiva;

(2) Uma vez que os grupos CHF e CLF foram selecionados a partir de sua resposta de congelamento a um contexto previamente associado a um estímulo aversivo, e que o hipocampo é uma estrutura-chave para a memória contextual do medo queríamos também investigar as alterações na proliferação celular em decorrência de situação aversiva, comparando a quantidade de neurônios positivos para BrdU, Ki-67 e DCX duas semanas após a reexposição à da situação aversiva em comparação com a neurogênese sob condições de normalidade em ratos previamente fenotipados;

(3) Tem sido mostrado que existem padrões naturais de resposta a estímulos aversivos condicionados com um envolvimento diferencial de estruturas cerebrais e de ativação de vias

neuroquímicas. Neste caso, estávamos interessados em estudar se a ativação das estruturas, já conhecidas, envolvidas no sistema de defesa, é igual nas diferentes linhagens. Estruturas como o córtex pré-frontal (BLANCO et al., 2009; DAVIDSON, 2002b; JAFERI e BHATNAGAR, 2007), a amígdala (BECKER et al., 2007; CUI et al., 2008; DAVIDSON, 2002a), o hipocampo (ANDREWS et al., 1997; BECKER et al., 2007; BOGOCH et al., 2007; BONNE et al., 2008) e o núcleo paraventricular (PVN), têm sido colocadas como parte do sistema de defesa, ativadas em situações de ansiedade (LAMPREA et al., 2002). Por tanto quisemos avaliar a imunoreatividade para c-Fos em estruturas envolvidas no comportamento de congelamento, após a finalização da situação aversiva; e

(4) Avaliar os efeitos de um antagonista preferencial de receptores 5- $\mathrm{HT}_{2 \mathrm{~A}}$, receptores que têm sido relacionados com a ansiedade generalizada, utilizando a dose de $0,5 \mathrm{mg} / \mathrm{Kg}$ que, 
conforme reportado na literatura, apresenta efeito ansiolítico sem afetar o comportamento locomotor. 


\section{Materiais e métodos}

\subsection{Animais}

Os CHF, CLF e RND (Wistar) das gerações 10, 11, 12 e 13 foram desenvolvidos seguindo procedimento descrito em Gomes e Landeira-Fernandez (2008) detalhado a continuação e mantidas na Pontifícia Universidade Católica do Rio de Janeiro (PUC-RJ) no Laboratório de Neuropsicologia Experimental e Humana do Departamento de Psicologia.

A amostra da matriz que gerou os grupos experimentais, identificada como S0, foi de 120 animais, sendo 60 machos e 60 fêmeas, submetidos aos testes de condicionamento na idade de aproximadamente três meses. A população utilizada para o Experimento 4 foi composta por machos da geração S10 e foram $16 \mathrm{CHF}, 20 \mathrm{CLF}$ e 21 RND. A população utilizada para o Experimento1 foi composta por machos da geração S11 e foram $8 \mathrm{CHF}, 10$ CLF e 9 RND. A população utilizada para o Experimento 2 foi composta por machos da geração S12 foram 12 CHF, 12 CLF e 12 RND. A população utilizada para o Experimento 3 foram machos da geração S13 12 CHF foram 12 CLF e 12 RND.

Os ratos foram mantidos em grupo de quatro por gaiola $(18 \times 31$ x $38 \mathrm{~cm}$ - altura $\mathrm{x}$ largura x comprimento) tendo livre acesso à água e comida, em um ciclo claro/escuro de 12 horas (início do ciclo claro as $6: 30 \mathrm{~h}$ ). A temperatura da sala foi mantida em $22 \pm 1^{\circ} \mathrm{C}$. Todos os experimentos foram feitos na fase clara do ciclo de luz. Os animais estavam com idade entre 90 e 120 dias no inicio dos experimentos. Antes de começar os experimentos, todos os animais foram manipulados durante cinco dias por 2 minutos cada. No caso dos animais utilizados para a dosagem de corticosterona, esses foram manipulados de acordo com os procedimentos especiais de manipulação propostos por Fluttert (2000), para amostras sequenciais feitas com incisão da cauda.

\subsection{Equipamentos}

Todos os animais foram fenotipados utilizando uma caixa de condicionamento aversivo $(25 \times 20 \times 20 \mathrm{~cm})($ Insight, Brasil) colocada dentro de uma caixa atenuadora de som (Figura 
4A). A caixa estava iluminada com uma luz vermelha $(25 \mathrm{~W})$ e tinha um som controlado com um gerador de ruído branco de $78 \mathrm{~dB}$. O chão da caixa possui um assoalho gradeado (15 barras de aço inoxidável, espaçadas a $1,5 \mathrm{~cm}$ ) a fim de permitir a passagem de choques elétricos. A corrente elétrica, de $0,5 \mathrm{~mA} / 1 \mathrm{~s}$, era liberada por meio de um estimulador de choques (Insight, Brasil). Uma solução de hidróxido de amônio a 10\% foi utilizada pra limpar a caixa depois do uso. Os comportamentos foram registrados e gravados com o programa GeoVision GV800 (PCI Systems, Reino Unido), instalado num computador numa sala anexa à sala de experimentação (Figura 4B).

A.

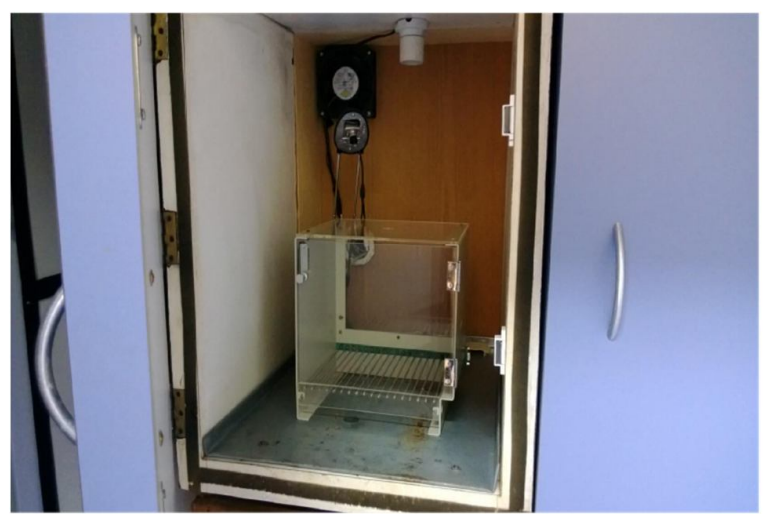

B.

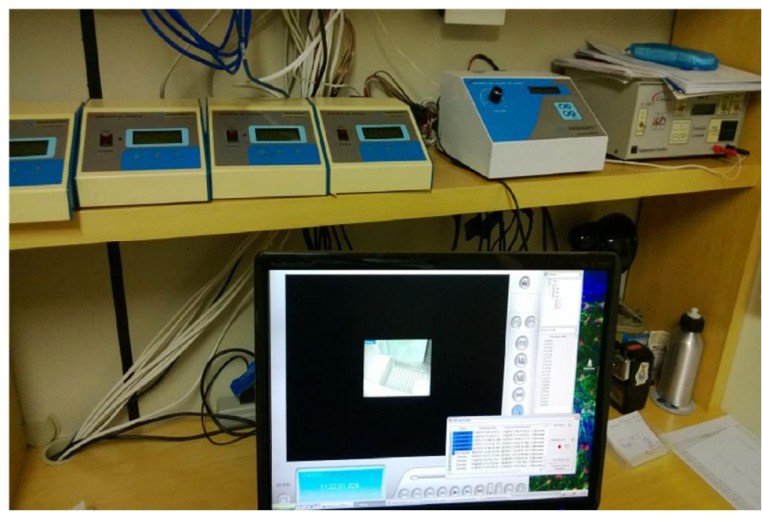

Figura 4. (A) Caixa de contexto (Insight, São Paulo, Brasil) colocada dentro de uma caixa atenuadora de som. (B) Programa GeoVision GV800 (PCI Systems; Reino Unido).

Para a avaliação do composto farmacológico (Experimento 4) foi utilizado um labirinto em cruz elevado. O aparelho consiste de duas superfícies horizontais de madeira, medindo $50 \times 10 \mathrm{~cm}$, justapostas pelas pontas, com bordas de acrílico de $1 \mathrm{~cm}$ de altura (braços abertos), para evitar a queda dos animais, cruzados em angulo reto com duas superfícies de igual tamanho, circundadas por paredes de $40 \mathrm{~cm}$ de altura (braços fechados), exceto na parte central onde os braços se cruzam. Todo o aparato eleva-se a $50 \mathrm{~cm}$ do chão. As sessões experimentais foram gravadas para a posterior análise. $\mathrm{O}$ analise foi feito com o programa Xplorat 3.0. (Freeware, Brasil).

\subsection{Procedimentos}

Todos os animais utilizados nos experimentos foram submetidos ao teste de medo condicionado ao completar aproximadamente o dia PN90 para comprovar a sua expressão fenotípica. O objetivo é separar os animais que exibem o comportamento ansioso (filhote de CHF) e não ansioso (filhote de CLF) comparado com os animais RND, que por sua vez são 
filhotes de cruzamento randomizado de ratos Wistar da mesma colônia. Como apresentado na Figura 5, na sessão de treino, cada animal foi colocado, individualmente, na caixa experimental, por 8 minutos. Os primeiros 8 minutos correspondem ao período de habituação. Seguia-se a apresentação de três choques de 0,6 mA, com duração de 1 segundo cada, e intervalo de 20 segundos entre os choques. Após esse primeiro procedimento, o animal permanecia na caixa por 3 minutos. Vinte e quatro horas depois, o animal foi recolocado na caixa por 8 minutos e filmado, por meio de uma câmera acoplada à caixa. Foi registrado o tempo em que exibia resposta de congelamento, definida como ausência total de movimentos, exceto por aqueles indispensáveis à respiração. Todos os animais selecionados para os testes destes experimentos expressavam o comportamento relativo à sua linhagem. Esperaram-se dois meses para continuar com os procedimentos experimentais.

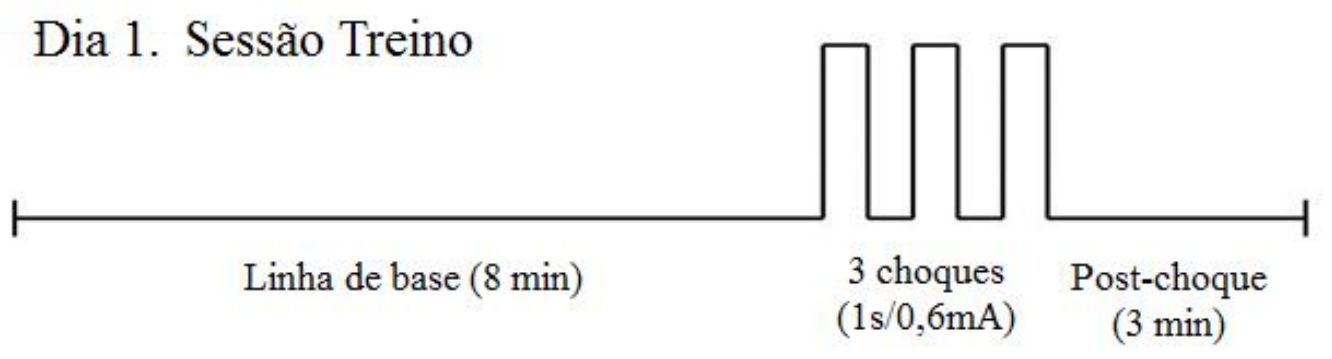

\section{Dia 2. Sessão de teste}

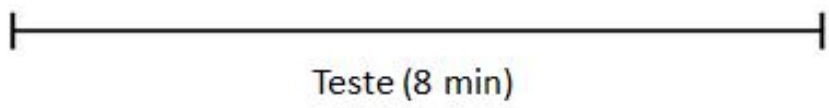

Figura 5. Esquema do paradigma de fenotipagem. Traduzido de Gomes (2012)

\subsubsection{Experimento 1: Concentracão plasmática de corticosterona em ratos $C L F$ e $C H F$ submetidos ao modelo de medo condicionado ao contexto.}

Antes dos animais serem submetidos ao resteste (dois meses após o treinamento e o teste) do medo condicionado, foi coletada uma primeira amostra de sangue para estabelecer a linha de base da concentração plasmática de corticosterona. 
A amostra foi obtida da veia lateral da cauda, coletando-se $0,3 \mathrm{~mL}$ de cada rato em tubos tipo Eppendorf heparinizados. Todas as amostras foram coletadas no período da manhã, entre 8:00 e 12:00 horas Após o procedimento os ratos voltaram às suas gaiolas.

Quinze dias depois os animais foram colocados na caixa de condicionamento. Nesta sessão, os animais foram colocados na caixa durante 5 minutos sem a presença do choque, 20 min depois foi coletada uma segunda amostra.

Depois as amostras foram centrifugadas à velocidade de $3000 \mathrm{rpm}$, à $4^{\circ} \mathrm{C}$ por 15 minutos. O plasma foi coletado e congelado à $-20^{\circ} \mathrm{C}$, até o momento da realização das dosagens.

\subsubsection{Medidas da concentração plasmática de corticosterona}

A concentração plasmática de corticosterona foi dosada pela técnica de radioimunoensaio de duplo anticorpo, no Laboratório de Neuroendocrinologia do professor Celso Franci, da Faculdade de Medicina de Ribeirão Preto da Universidade de São Paulo, Ribeirão Preto (FMRP-USP). Como foi descrito por Berson e Yalow (1968), para avaliar a concentração de corticosterona plasmática se coloca corticosterona marcada radioativamente a competir com a corticosterona presente na amostra. Assim, o aumento gradativo da concentração de corticosterona diminui progressivamente a taxa de ocupação da corticosterona marcada (THORELL ; LARSON, 1978). Foram utilizados padrão e anticorpos produzidos no laboratório do professor Celso Franci e hormônio triciado fornecido pela Amershan Biosciences (Reino Unido). As amostras foram dosadas em duplicata no mesmo ensaio para controlar variações interensaios. O limite mínimo de detecção foi $2 \mathrm{ng} / \mathrm{dL}$ e o coeficiente de variação intraensaio foi de $5 \%$.

\subsubsection{Experimento 2: Proliferacão celular no hipocampo dos ratos $C L F, C H F$ e RND submetidos ao modelo de medo condicionado ao contexto e ao estresse de contencão motora e estresse crônico variado.}

Para este experimento, dois meses após ser submetidos ao procedimento de fenotipagem, a metade dos ratos começou um período de contenção (3 horas por dia durante duas semanas, Figura 6A) acompanhado de uma modificação do protocolo de estresse crônico variado (ECV) utilizado em Leon et al. (2009). Os estressores incluíam um período continuo de luz durante 24 h, um período de privação de comida e outro de água durante a noite. Um período de maravalha molhada, inclinação da caixa $45^{\circ}$ (Figura 6B), uma hora de plataformas 
elevadas (Figura 6C), dentre outros. A outra metade dos ratos permanecia na caixa de alojamento em condições controle. Nas últimas 48 horas do protocolo de estresse, os animais receberam quatro injeções de $\mathrm{BrdU}(100 \mathrm{mg} / \mathrm{Kg}$, i.p.) duas vezes por dia, intervalo de 12 horas, seguindo o protocolo proposto em Wojtowicz e Kee (2006).

A.

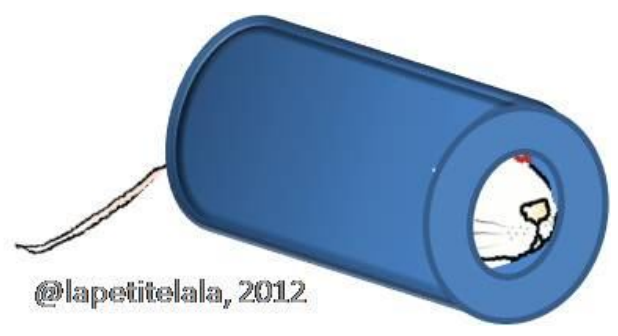

B.

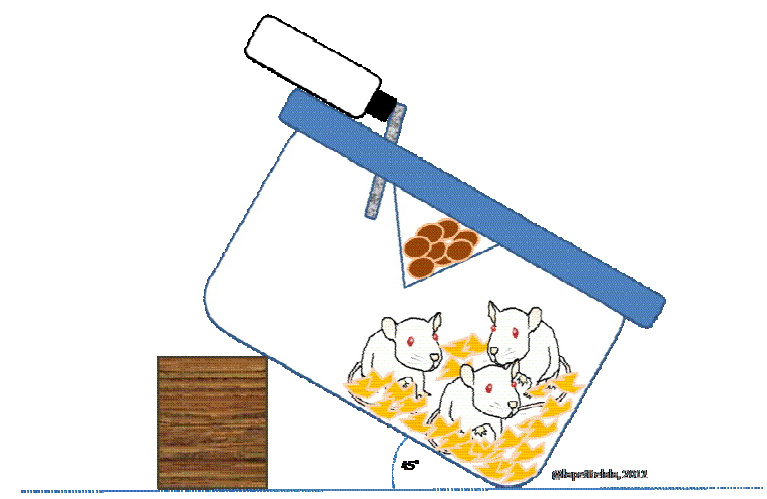

C.

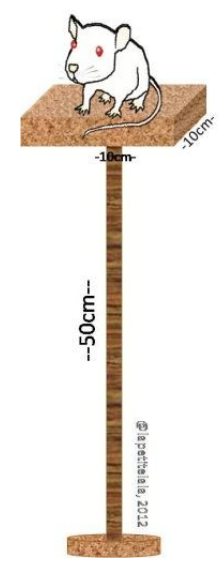

Figura 6. Alguns estressores utilizados para a avalição da proliferação neuronal (A) 3 horas diárias de contenção durante duas semanas. (B) 3 períodos de 9 horas de inclinação da caixa. (C) Uma hora nas plataformas elevadas.

\subsubsection{Imunoistoquímica}

Os animais utilizados para a marcação de proliferação foram sacrificados 24 h após a última injeção; aqueles utilizados para avaliação de sobrevivência foram sacrificados três semanas após a última injeção. Foram anestesiados com Ketamina $(0,75 \mathrm{mg} / \mathrm{mL})$ e Xilazina $(0,05 \mathrm{mg} / \mathrm{mL})$, para realizar a perfusão intracardíaca com PBS $(200 \mathrm{~mL})$ seguida de $(200 \mathrm{~mL})$ paraformaldeído 4\% tamponado em PBS ( tampão fosfato salina 0,1 M; pH 7,4). Em seguida, os encéfalos foram removidos, pós-fixados em paraformaldeído tamponado a $4 \%$ por duas horas e crioprotegidos em solução de sacarose a 30\% (em PBS 0,01M; pH 7,4) durante 48 horas. Depois foram congelados em isopentana por 30 segundos, e armazenados em freezer a $-70^{\circ} \mathrm{C}$ até o momento da obtenção dos cortes. 
Cortes seriados de $50 \mu \mathrm{m}$ foram obtidos em criostato (CM 1800 Leica, Alemanha) ao longo do hipocampo dorsal e ventral e foram colhidos em séries de um a seis aproximadamente, desde a coordenada correspondente a interaural 7,08 $\mathrm{mm}$ até interaural 3,00mm de Paxinos \& Watson (2007), o que da uma distância aproximada de $240 \mu \mathrm{m}$ entre os tecidos. Foram distribuídos em placas de seis poços, contendo solução tampão tris-salina crioprotetora, com 15\% de sacarose e 30\% de glicerol (TBS-AF), armazenados até a realização da imuno-histoquímica à $4^{\circ} \mathrm{C}$. Cada poço foi selecionado para diferentes tratamentos (p.e. imuno-histoquímica para BrdU).

Os ensaios de imuno-histoquímica free floating para Ki-67 (proliferação celular), DCX (neurônios imaturos) foram desenvolvidos no laboratório de Neurobiologia da Retina do Instituto de Biofísica Carlos Chagas Filho, da Universidade Federal de Rio de Janeiro sob a orientação da professora Patrícia Gardino. Os tecidos foram transferidos para placas de seis poços contendo TBS a temperatura ambiente. Após três lavagens com TBS, em agitadora orbital, a uma temperatura aproximada de $25^{\circ} \mathrm{C}$. As trocas foram feitas por aspiração com pipetas plásticas. Seguiu-se a pré-incubação dos cortes em $1 \%$ de $\mathrm{H}_{2} \mathrm{O}_{2}$ (30 min), para diminuir a marcação não especifica. Apos foram lavados com TBS três vezes seguindo-se incubação por duas horas a temperatura ambiente, com uma solução de $15 \%$ de soro normal de cavalo em TBS-Triton. Os cortes foram incubados por 12 horas em solução de TBS-Triton, contendo anticorpo primário anti-Ki-67 (1:500, Abcam, AB16667, Reino Unido) e 10\% de soro de cavalo. Após o período de incubação com anticorpo primário, os cortes foram lavados 3 vezes com TBS e incubados com o anticorpo secundário (1:200) biotinilado anti-cavalo feito em coelho (Vector, EUA) em solução $10 \%$ de soro de cavalo. Os cortes foram novamente lavados em TBS e incubados com ABC (complexo avidina-biotina; Kit Elite Vectastain, Vector - 1:1000, EUA) por duas horas, a temperatura ambiente. Por último, após três lavagens em TBS, a reação foi revelada por $0,5 \mathrm{mg} / \mathrm{mL}$ de DAB diluído em tampão tris 0,05 M em peróxido $0,02 \%$, por dez minutos, e a reação foi parada por imersão em TBS gelado. Os cortes foram finalmente lavados com TBS e montados em lâminas gelatinizadas. Após desidratação e hidratação, as lâminas foram montadas com Entellan (Merck, HX075822, Alemanha).

No caso do DCX foi utilizado o mesmo procedimento, utilizando o anticorpo primário anti-DCX (1:200, Santa Cruz, EUA) e 1\% de soro de cavalo e anticorpo secundário HRP anticavalo feito em cabra (1:200,Vector).

Para BrdU foi necessária a incubação por trinta minutos com $\mathrm{HCl}$ a $2 \mathrm{~N}$ em estufa de $\mathrm{CO} 2$ a $37^{\circ} \mathrm{C}$. Após os tecidos passaram por um tratamento com tampão borato de sódio a 0,15 
M, duas vezes durante 10 minutos cada. $\mathrm{O}$ anticorpo primário foi o anti $\operatorname{BrdU}$ (1:200; Abcam) o secundário Alexa flúor 568 ( anti rat; 1:1000; Molecular Probes, Brasil). Para as duplas marcações os neuronios foram marcados com anticorpo anti NeuN (1:300; mouse, Alemanha) e o anticorpo secundário foi o Alexa flúor 488 (anti mouse; 1:400, Brasil).

\subsubsection{Contagem}

O número total de células imunoreativas para Ki67 e DCX (IR) no giro denteado do hipocampo foi estimado utilizando uma versão modificada do método de fracionado óptico em uma amostra aleatória sistemática, contando cada 6 secções a longo do eixo rostro-caudal da formação hipocampal. Os corpos celulares foram identificados e contados nos dois hemisférios, utilizando um microscópio MEIJI (EUA) com uma objetiva de 40X ,conectado a uma câmera Nikon de 13,5 Mpx, ligado a um computador no Laboratorio de Neurociencia e Comportamento da Universidad de los Andes, Bogotá- Colombia.

\subsubsection{Experimento 3: Expressão da proteína c-FOS nos ratos $C L F, C H F$ e RND submetidos ao modelo de medo condicionado ao contexto.}

Os animais (CHF, CLF e RND) foram colocados na caixa de condicionamento e seguiram o protocolo do experimento descrito no Experimento 1. Duas horas após o teste do medo condicionado, intervalo necessário para a síntese e acúmulo da proteína FOS (MORGAN; CURRAN, 1991), os animais foram perfundidos seguindo o protocolo de perfusão descrito no Experimento 2. Os cérebros foram transportados ao laboratório de psicofarmacologia do Professor Marcus Lira Brandão, na Universidade de São Paulo, Ribeirão Preto. Neste caso os cortes foram de $40 \mu \mathrm{m}$ e foram coletados em recipientes contendo PBS (0,1M). Para cada região se selecionaram dois cortes, um especifico para backup que foi colocado em solução anticongelante e armazenado no freezer a $-20^{\circ} \mathrm{C}$. Cada estrutura teve como referencias as seguintes coordenadas, segundo o atlas de Paxinos e Watson (2007):

Bregma 5,64 - Córtex orbital medial (MO)

Bregma 3,00 - Córtex pré-límbico (PrL) Córtex Infralímbico (IL)

Bregma 1,8 - Córtex cingulado 1 (Cg1), Córtex Cingulado $2(\mathrm{Cg} 2)$ e Área motora secundaria $(\mathrm{M} 2)$ 
Bregma 1,08 - Septum medial (MS), Septum Hipocampal (SH) e Septum Lateral Dorsal (LSD)

Bregma -1,92 - Núcleo paraventicular do Hipotálamo (PVN) e Hipotalamo Ventromedial (HVM)

Bregma -3,00 - Giro denteado (GD), Núcleo central da Amigdala (CeA) e Núcleo basolateral da Amigdala (BLA).

Bregma -7,32 - Substância cinzenta periaquedutal dorsal (PAGd) e Substância cinzenta periaquedutal ventral (PAGv).

Bregma -9,84 - Locus Coeruleus (LC).

Ver Figuras 7 e 8. 


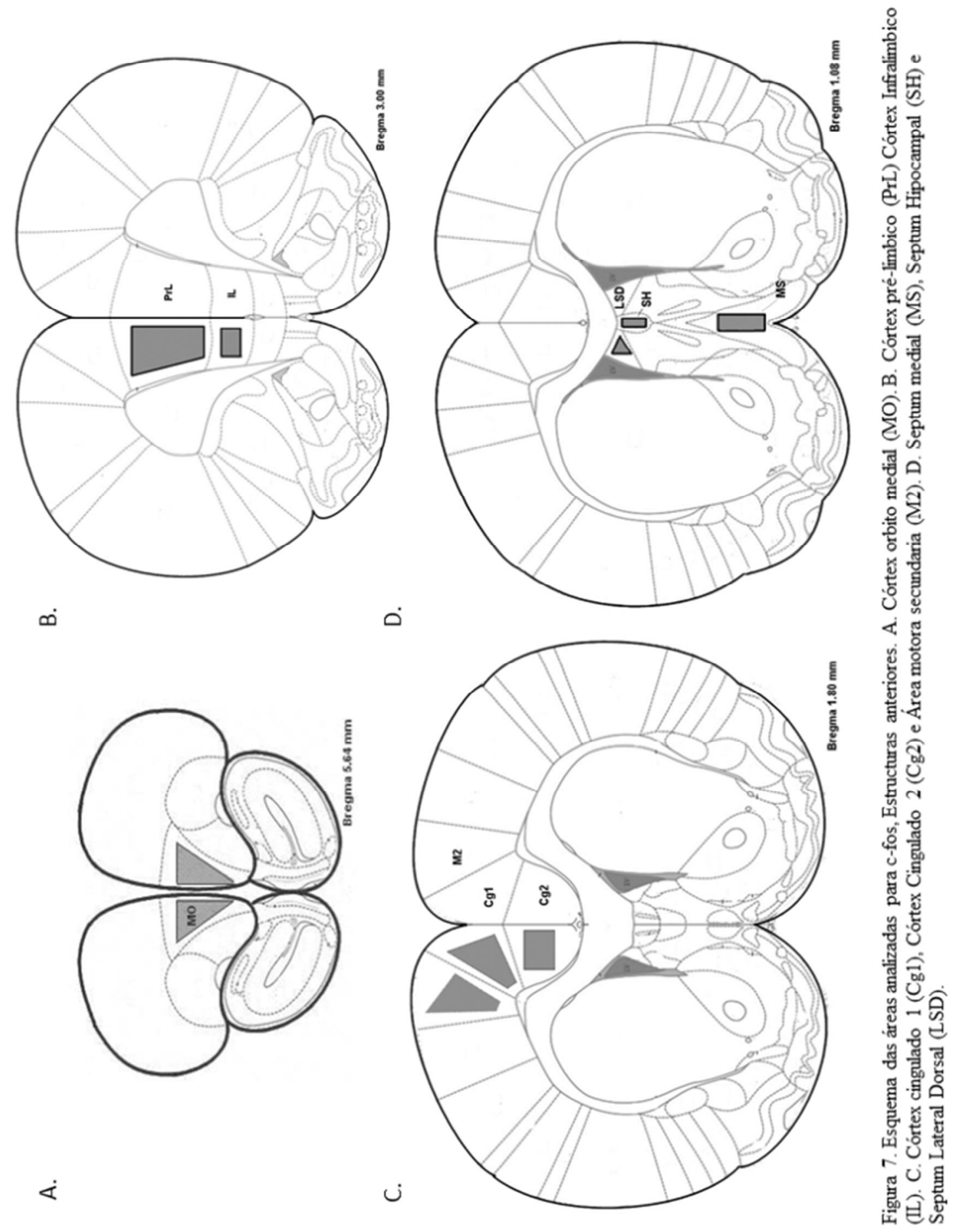




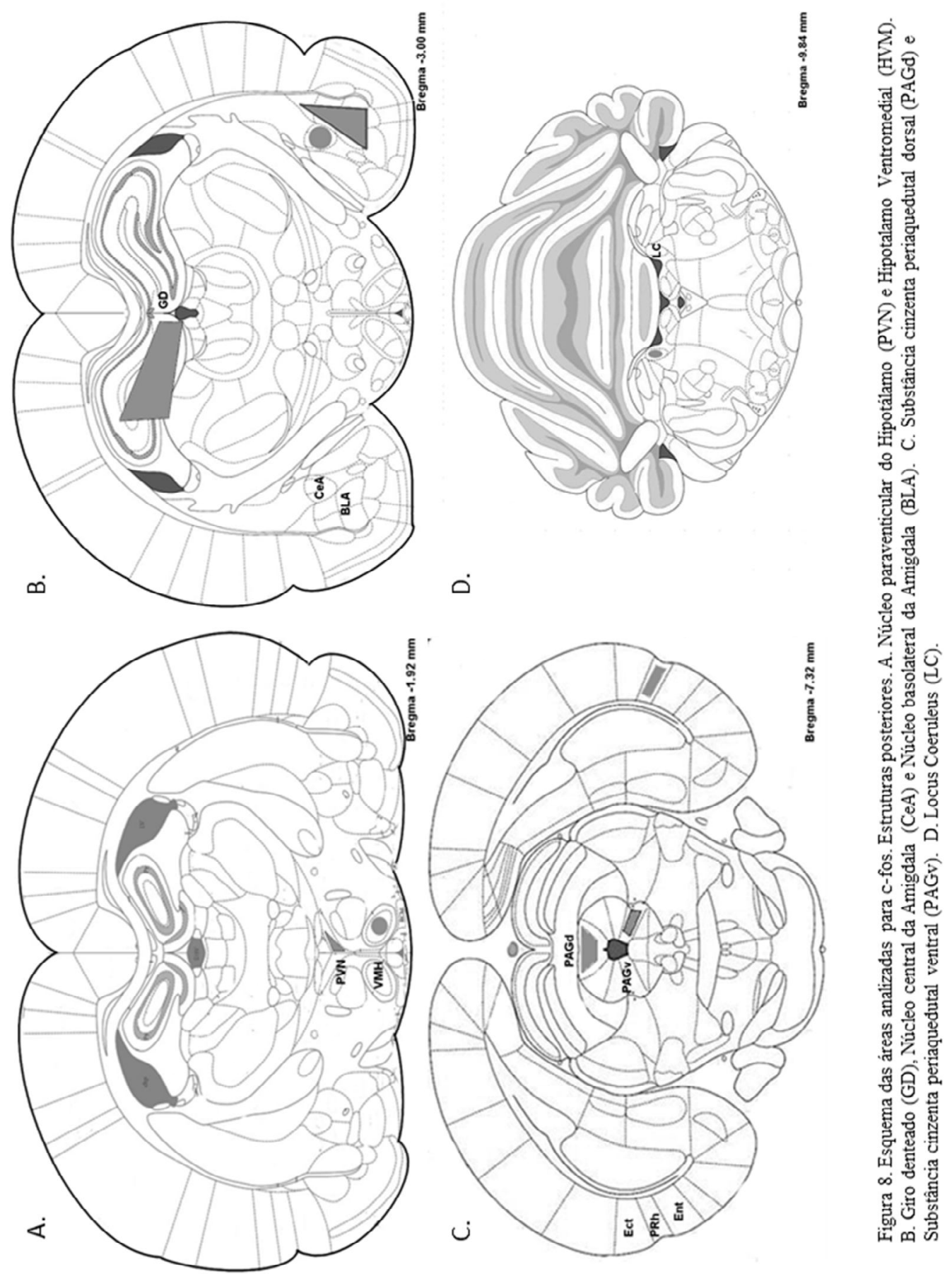




\section{Imunoistoquímica}

O mesmo procedimento para KI67 utilizando como anticorpo primário policlonal antifos produzido em coelho (Santa Cruz, 1:2000, EUA) em PBS+ (PBS 0,1 M com soro albumina bovina, $1 \mathrm{mg} / \mathrm{mL}$ e detergente triton $\mathrm{X}-100,2 \mu \mathrm{L} / \mathrm{mL})$. O anticorpo secundário foi o anticorpo policlonal anticoelho biotinilado (Kit ABC Elite, Vectastain, Vector, 1:400 em PBS+,EUA). O tetracloreto de diaminobezidina (DAB; Sigma, EUA) foi utilizado como cromógeno, os cortes foram incubados durante 10-15 min para revelação da atividade da peroxidasse, e em seguida foram lavados 3 vezes. Para a montagem das lamínulas foi utilizado Permount.

\subsubsection{1. $\quad$ Análise quantitativa da expressão da proteína Fos}

A contagem de células Fos+ (Fos-IR) foi feita seguindo o protocolo utilizado no Laboratório de Psicofarmacologia do Programa em Psicobiologia da FFCLRP (BORELLI, 2006; ALBRECHET, 2010) utilizando um microscópio (Olympus, BX-50 x100, acoplado a uma videocâmara Leica DFC320, Alemanha). A imagem foi digitalizada e analisada com o programa Image Pro-Plus 6.2, (Media Cybernetics, EUA). Antes de serem feitas todas as contagens, foi utilizada uma planilha com a área da estrutura delimitada pelo experimentador, baseada no atlas de Paxinos e Watson (2005) e depois se normalizaram os dados a $0,1 \mathrm{~mm}^{2}$ dividindo o número total de sinais positivos Fos-IR pela área delimitada.

\subsubsection{Experimento 4: Efeitos do antagonista serotoninérgico 5-HT ${ }_{2 \mathrm{~A}}$, ketanserina nos ratos CHF, CLF e RND submetidos ao teste labirinto em cruz elevado}

\subsubsection{Drogas}

Tartarato de Ketanserina $(0.5 \mathrm{mg} / \mathrm{Kg}$; Sigma-Aldrich, EUA) foi dissolvido em $2 \%$ de dimetil sulfóxido (DMSO) ou $5 \mathrm{nmol} / \mu \mathrm{L}$ na dose para ser injetada intracerebralmente. A dose foi selecionada de acordo com trabalhos prévios tal como fora mencionado no item 1.7. (MOTTA et al., 1992; OLIVEIRA, 2007; OLIVEIRA et al., 2007). Os animais controle receberam DMSO a 2\% (Vei; Veiculo). Um grupo controle foi feito com salina a $0,9 \%$ e não foram observadas diferenças com o grupo tratado com DMSO a $2 \%$. 


\subsubsection{Cirurgia}

Dois meses após a fenotipagem os animais foram anestesiados I.P. com Ketamina $(0,75 \mathrm{mg} / \mathrm{mL})$ e Xilazina $(0,05 \mathrm{mg} / \mathrm{mL})$. O crânio do animal foi fixado ao aparelho estereotáxico (Insight, Brasil). A barra dos incisivos foi fixada a $-3,3 \mathrm{~mm}$ sentido dorso ventral. Colocaram-se duas cânulas $26 \mathrm{G}$ com $7 \mathrm{~mm}$ de comprimento, bilateralmente dirigidas ao Córtex PrL Foram fixadas ao crânio com uma resina acrílica e um parafuso de aço inoxidável. As coordenadas utilizadas foram tomadas a partir do Bregma e selecionadas com base no atlas de Paxinos e Watson (2005): 3,24mm anteroposterior, 0,5mm lateral, 2,4 dorsoventral. Foi administrado um antibiótico de largo espectro (I.M. Pentobarbital Veterinário, Fontoura-Wyeth, Brasil) e uma solução analgésica e anti-inflamatória (S.C.Banamine, Intervet/Schering-Plough, Brasil). Esperaram-se 6 dias antes dos procedimentos experimentais.

\subsubsection{Injeção}

A ketanserina $(0.5 \mathrm{mg} / \mathrm{Kg})$ ou veículo foram injetadas intraperitonealmente $(1 \mathrm{~mL} / \mathrm{Kg})$ no caso do grupo de aplicação sistêmica ou localmente $(5 \mathrm{nmol} / \mu \mathrm{L})$, no córtex PrL, no caso do grupo de microinjeção intracerebral. No caso da injeção local foram utilizadas agulhas odontológicas conectadas a seringas Hamilton por meio de tubos de polietileno (PE-10). O volume de $0,5 \mu \mathrm{L}$ foi injetado bilateralmente durante um minuto, por meio de uma bomba de microinfusão (Harvard, EUA). Trinta minutos após a injeção ou 10 minutos depois, respetivamente, os animais foram submetidos ao LCE. Cada rato foi colocado no quadrado central do labirinto, com o focinho em direção ao braço fechado e lhe era permitido explorar o labirinto por $5 \mathrm{~min}$.

\subsubsection{Medidas comportamentais}

O comportamento exploratório dos ratos foi avaliado de acordo com os seguintes parâmetros

- Frequência de entrada e tempo nos braços abertos: Número de vezes em que o animal atravessa com as quatro patas para os braços abertos do labirinto e tempo despendido. 
- Frequências de entrada e tempo nos braços fechados: Número de vezes em que o animal atravessa com as quatro patas, para os braços abertos do labirinto e tempo despendido.

- Porcentagem de tempo nos braços abertos: tempo despendido nos braços abertos em relação ao tempo total do teste.

- Porcentagem de tempo nos braços fechados: tempo despendido nos braços fechados em relação ao tempo total do teste.

Outros comportamentos foram também avaliados com base em Garcia, Cárdenas e Morato (2005)

- Exploração da extremidade aberta: frequência e tempo de permanência com as quatro patas na porção distal dos braços abertos.

- Dipping: frequência e tempo do mergulho da cabeça nos laterais ou extremidades dos braços abertos do labirinto em direção ao solo.

- Head out: frequência e tempo do esticamento da cabeça nem direção à parede sem mergulho.

- Rearing: frequência e tempo na postura exploratória na qual o rato se apoia verticalmente sobre as patas posteriores no assoalho.

- Esticamento: frequência e tempo na postura exploratória de esticamento horizontal no qual o rato ocupa $3 / 5$ do braço no qual está.

\subsection{Análise estatística}

O software utilizado para as analises foi o Systat Software, Inc. versão 3,5. (EUA) Os dados são apresentados como as medias \pm EPM.

No Experimento 1, os resultados comportamentais (tempo total de congelamento) assim como os resultados da concentração de corticosterona obtidos antes e após o modelo de medo condicionado foram analisados utilizando a análise de variância de um fator para medidas repetidas.

No Experimento 2, o número de neurônios positivos para, KI-67, DCX, NeuN e BrdU foi comparado utilizando a análise de variância ANOVA, de um fator.

No Experimento 3, o número de neurônios positivos para c-FOS foi comparado utilizando análise de variância ANOVA, de um fator. 
No Experimento 4, o número de entradas e a porcentagem de tempo nos braços abertos e outras medidas comportamentais, como a distância total percorrida foi comparado utilizando a análise de variância de duas vias (ANOVA).

Quando foi necessário foram feitas comparações post-hoc entre grupos utilizando o teste Newman-Keuls. Em todos os testes só aqueles resultados com $\mathrm{p}<0.05$ foram considerados estatisticamente significativos.

\subsection{Considerações éticas}

Todos os esforços foram feitos para evitar sofrimento desnecessário aos animais. Todos os protocolos foram realizados de acordo com as normas da Sociedade Brasileira de Neurociências e Comportamento $(\mathrm{SBNeC})$ e do Colégio Brasileiro de Experimentação Animal (COBEA). O projeto faz parte do projeto temático do professor Jesus Landeira Fernandez, intitulado "Sistema motivacional de defesa e sua relação com os transtornos de ansiedade: investigações com modelos animais e humanos", que foi aprovado pelo Comitê de Ética em pesquisa do Departamento de Psicologia da PUC-RJ (protocolo $n^{\circ}$ 20/2009). 


\section{Resultados}

\subsection{Experimento 1: Concentracão plasmática de corticosterona de ratos $C L F, C H F e$ $\underline{R N D}$ submetidos ao teste de medo condicionado ao contexto.}

$\mathrm{Na}$ Figura 9 ilustra-se a porcentagem de congelamento dos ratos das duas linhagens e o grupo RND, no pré-teste, teste e reteste. A ANOVA, de duas vias para medidas repetidas, mostrou que a linhagem, as sessões e a interação entre linhagem e sessão produziram efeitos estatisticamente significativos na porcentagem do congelamento $\left[\mathrm{F}_{(2,18)}=18,75 ; \mathrm{F}_{(2,36)}=30,19\right.$ e $F_{(4,36)}=10,06$, respectivamente; $p<0,001$ em todos os casos].

A análise post-hoc revelou que os animais RND e CHF apresentaram maior porcentagem de congelamento no teste e no reteste, com respeito ao pré-teste. Essa diferença não foi observada no grupo CLF. Revelou-se também que os CHF apresentaram no teste e no reteste maior porcentagem de congelamento, que os animais RND e os CLF. Os ratos CLF apresentaram uma menor porcentagem de congelamento, que os ratos RND e os CHF na sessão teste e reteste.

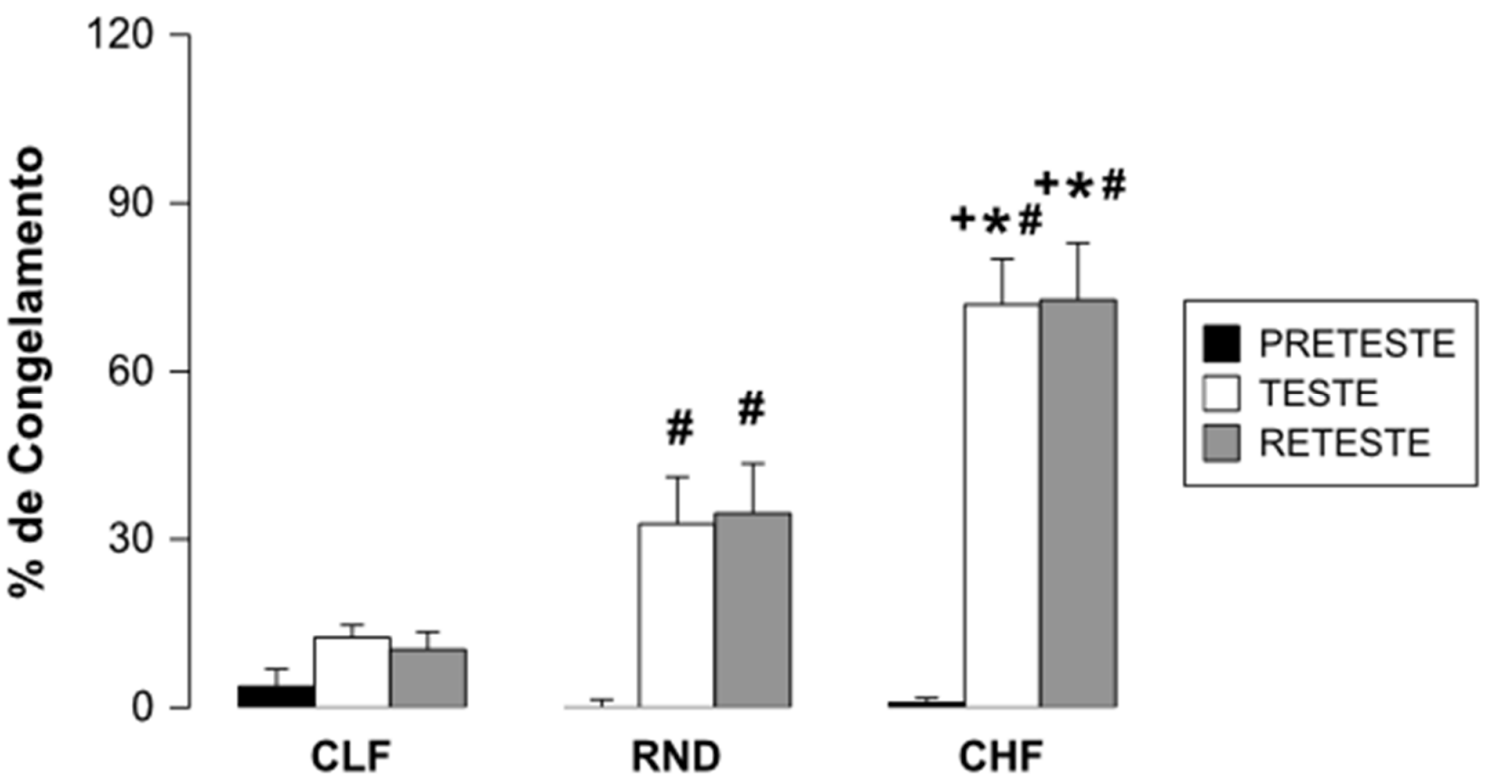

Figura 9. Porcentagem de congelamento nos ratos submetidos às sessões pré-teste, teste e reteste no medo condicionado ao contexto. Os valores estão apresentados como média + EPM. \# diferente da sessão pré-teste do mesmo grupo. + diferente do grupo RND na mesma sessão. * diferente do grupo CLF na mesma sessão ( $\mathrm{p}<0,001$, teste post-hoc Newman Keuls, $\mathrm{n}=7$ ).

A Figura 10 ilustra a concentração plasmática de corticosterona antes da sessão pré-teste (T1) e 20 minutos após o resteste (T2). A ANOVA de duas vias para medidas repetidas 
mostrou efeitos estatisticamente significativos no fator linhagem $\left[\mathrm{F}_{(2,18)}=8,008 ; \mathrm{p}<0,05\right]$ e no tempo da coleta de amostra $\left[\mathrm{F}_{(1,13)}=27,184 ; \mathrm{p}<0,001\right]$, mas não na interação $\left[\mathrm{F}_{(2,13)}=3,195\right]$.

A análise post-hoc revelou que os CHF apresentam concentrações de corticosterona basais maiores em comparação aos ratos CLF e os RND. Animais RND e CHF também apresentaram um aumento da concentração plasmática de corticosterona, após serem submetidos ao reteste do medo condicionado ao contexto, em comparação às concentrações basais, mas esse efeito não foi observado nos ratos CLF. Os CHF apresentaram também maior concentração plasmática de corticosterona após o teste em comparação com os RND e os CLF.
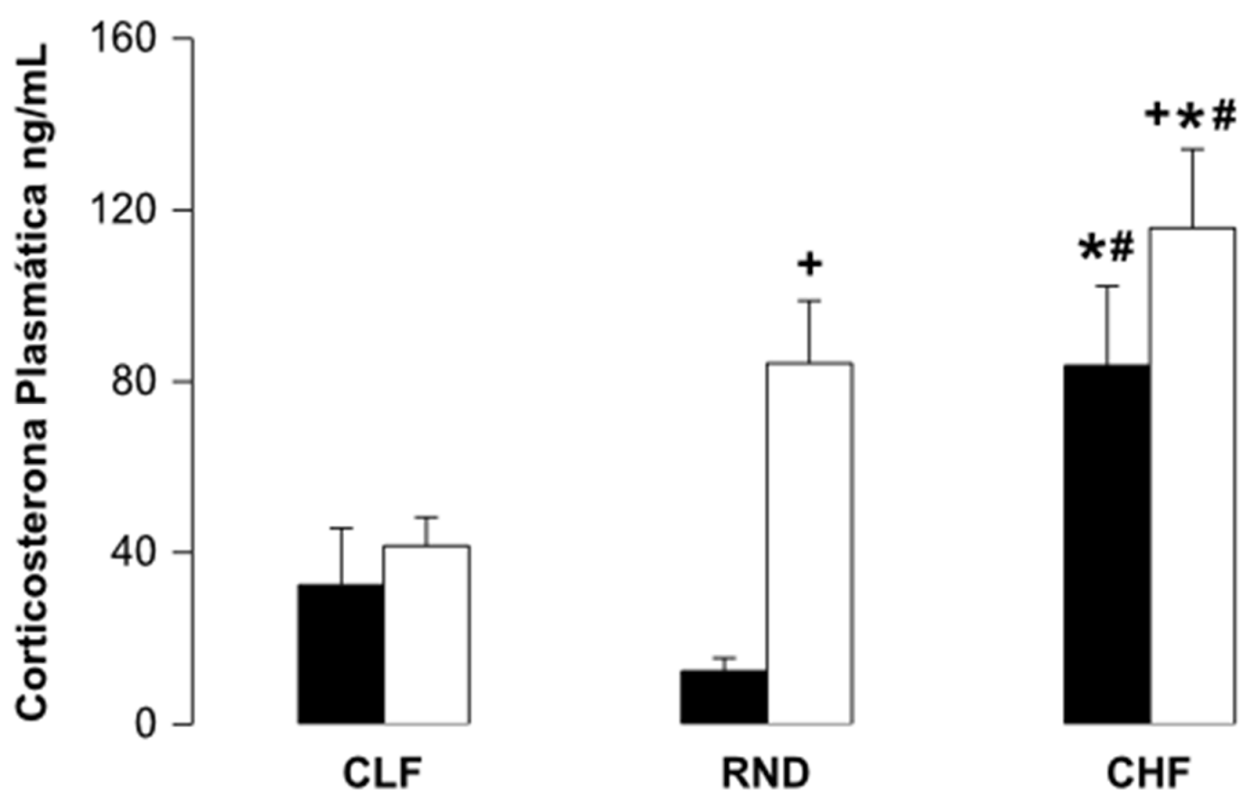

Figura 10. Concentração da corticosterona plasmática nos ratos RND, CLF e CHF antes (T1) e após (T2) serem submetidos ao reteste no medo condicionado ao contexto. Os valores estão apresentados como média + EPM. + diferente da concentração basal (T1) do mesmo grupo. * diferente do grupo RND no mesmo tempo. \# diferente do grupo CLF no mesmo tempo ( $\mathrm{p}<0,05$, teste post-hoc Newman Keuls, $\mathrm{n}=7$ )

\subsection{Experimento 2: Proliferacão celular dos ratos $C L F$ e CHF submetidos ao modelo de medo condicionado ao contexto e a estresse de contenção motora e estresse crônico variado}

Para estudar a proliferação celular foi feita a imuno-histoquímica para KI67. Com a imuno-histoquímica para DCX é possível ver o número de neurônios imaturos de aproximadamente duas semanas de idade. Na Figura 11 apresentam-se fotomicrografias representativas do hipocampo onde os pontos escuros são neurônios DCX+ e na Figura 12 são 
neurônios KI67+. As contagens foram feitas de acordo com três divisões: rostral (Bregma $1,08 \mathrm{~mm}--3,2 \mathrm{~mm}$ ) media (Bregma $-3,2 \mathrm{~mm}--4,4 \mathrm{~mm}$ ) e caudal (Bregma $-4,56 \mathrm{~mm}--6,6 \mathrm{~mm}$ ) do hipocampo de acordo com as coordenadas de Paxinnos e Watson (6ta edição).

Como é apresentado na Figura 12, a ANOVA para duas vias encontraram-se diferenças significativas entre o número de células positivas para KI67 entre as linhagens $\left[\mathrm{F}_{(2,21)}=4,386, \mathrm{p}<0,05\right]$, mas não se encontraram diferenças no fator estresse ou na interação. O teste post-hoc Student Newman Keuls mostrou que os ratos CHF apresentaram menos quantidade de células novas que os ratos RND. 
A.

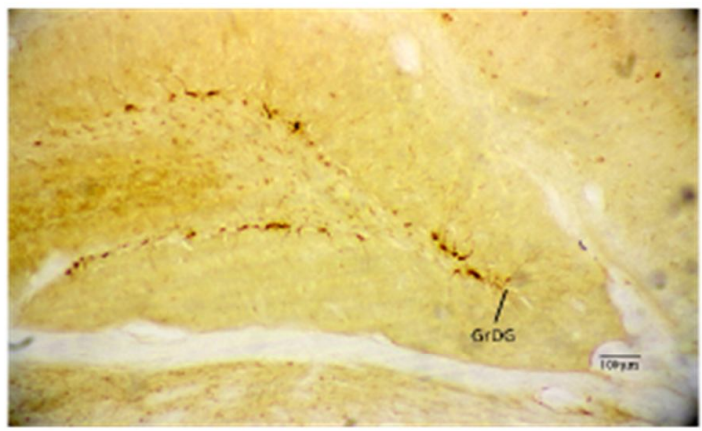

B.

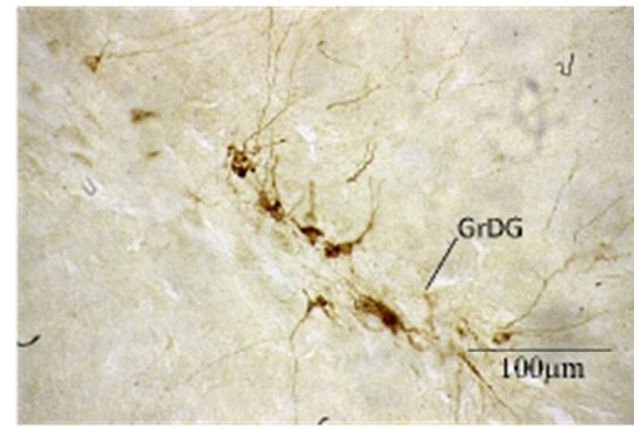

c.

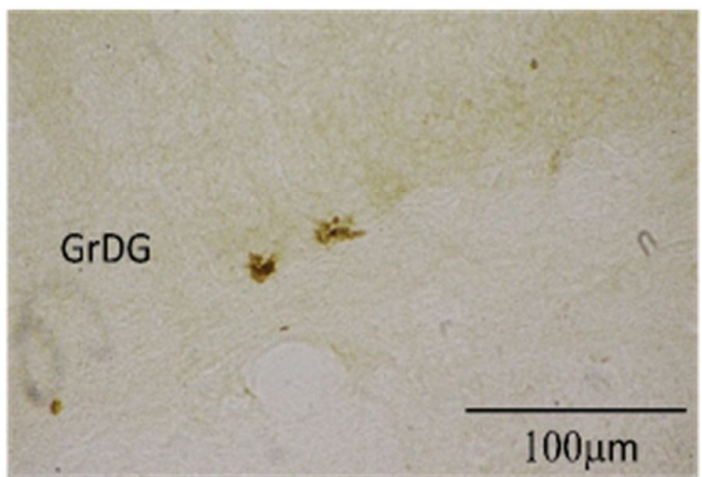

D.

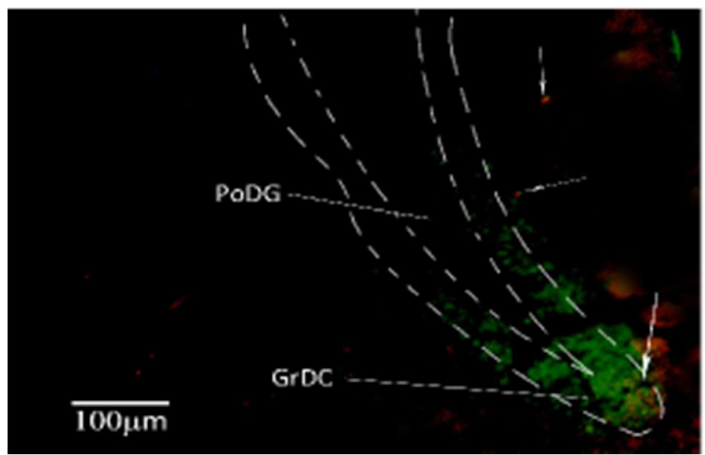

E.

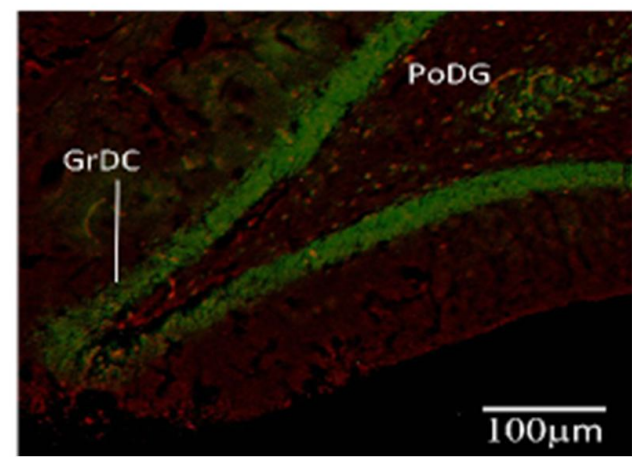

Figura 11. Fotomicrografias de secções coronais $(50 \mu \mathrm{m})$ representativas do hipocampo de encéfalos de ratos. Ilustra-se a imunoreatividade para DCX+ (11A e B), KI67+ (11C) e a dupla marcação de BrdU-NeuN (11D) e BrdU- GFAP (11E) 


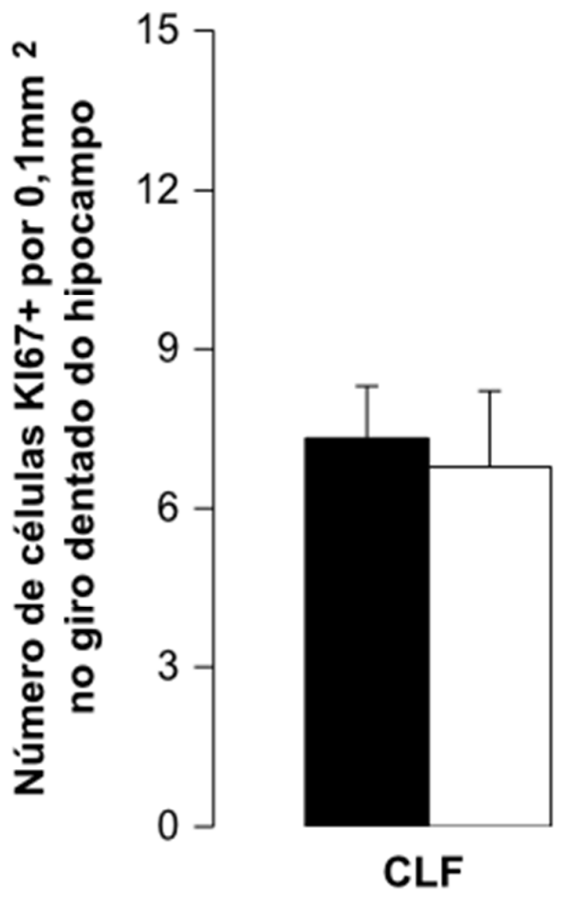

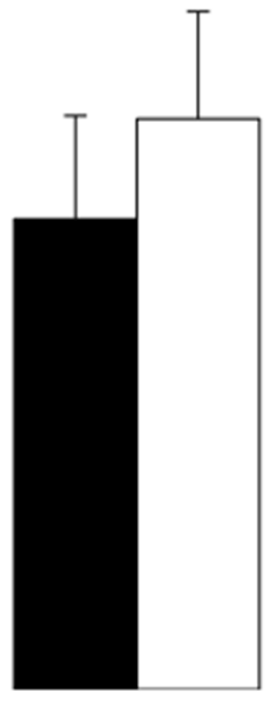

RND
Não estressado

Estressado

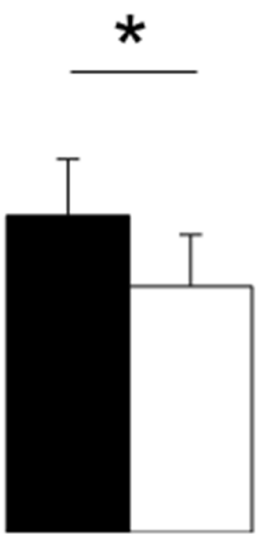

CHF

Figura 12. Histograma representativo de neurônios KI67+ por $0,1 \mathrm{~mm}^{2}$ no giro denteado do hipocampo dos ratos CLF , RND e CHF submetidos a estresse de contenção motora e estresse crônico variado ou não, após ser submetidos ao modelo de medo condicionado. Os valores estão apresentados como média + EPM. * diferente dos ratos da linhagem RND ( $<<0,05$, teste post-hoc Newman Keuls, n=4-7)

A ANOVA de duas vias dos dados da imunologia para DCX com os fatores linhagem e estresse mostrou que houve diferença significativa no fator estresse $\left[F_{(1,25)}=9,693\right.$, $p<$ 0,005], mas não no fator linhagem nem na interação. Como é observado na Figura 13. Os ratos submetidos ao protocolo de estresse apresentam menor quantidade de neurônios por $0,1 \mathrm{~mm}^{2}$ no giro denteado do hipocampo. O analise post-hoc Student Newman Keuls mostrou que essa diferencia é observada principalmente nos ratos CHF. 

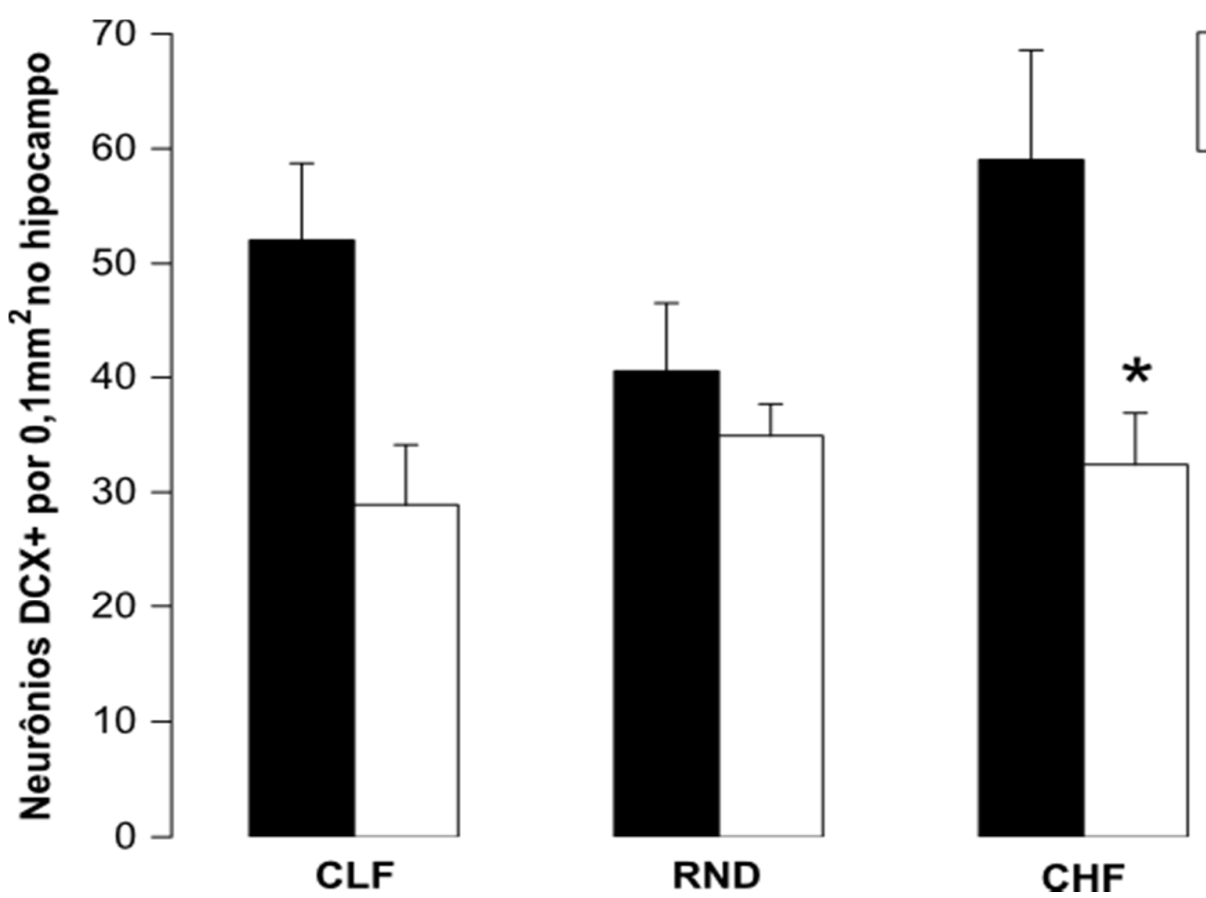

Figura 13. Histograma representativo de neurônios DCX+ por $0,1 \mathrm{~mm}^{2}$ no giro denteado do hipocampo dos ratos CLF , RND e CHF submetidos a estresse de contenção motora e estresse crônico variado ou não, após ser submetidos ao modelo de medo condicionado. Os valores estão apresentados como média + EPM. * diferente do grupo não estressado da mesma linhagem ( $\mathrm{p}<0,001$, teste post-hoc Newman Keuls, n=4-7)

Todavia, a análise qualitativa de cortes marcados por imunohistoquímica indicou menor imunomarcação para BrdU, marcador de células em proliferação,.

\subsection{Experimento 3: Expressão de c-FOS nos ratos CLF e CHF submetidos ao modelo de medo condicionado ao contexto}

Na Figura 14 apresentam-se fotomicrografias representativas do PrL onde os pontos escuros são neurônios Fos+ de ratos RND, CLF e CHF reexpostos ao contexto onde foram previamente condicionados. 
A.

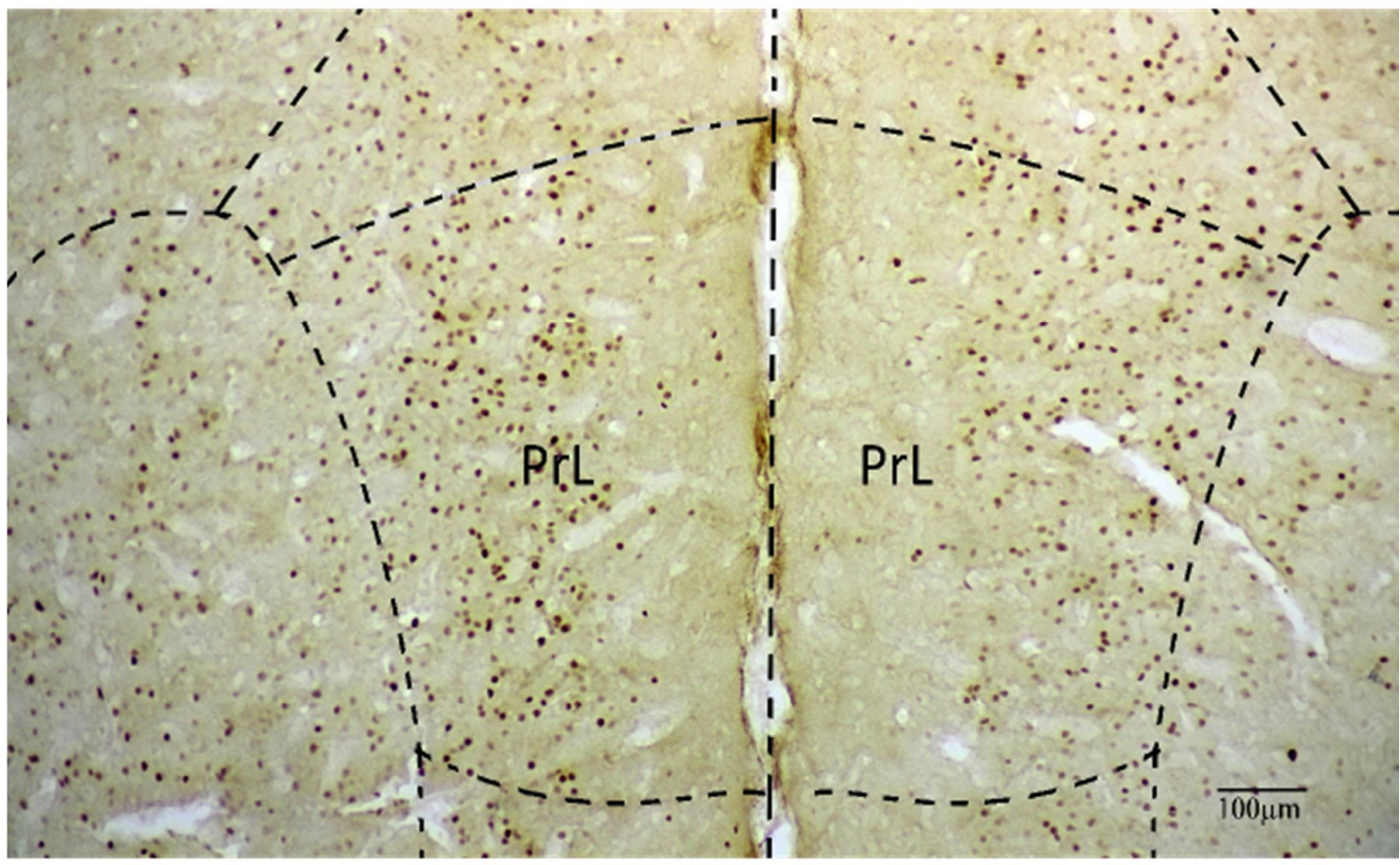

B.

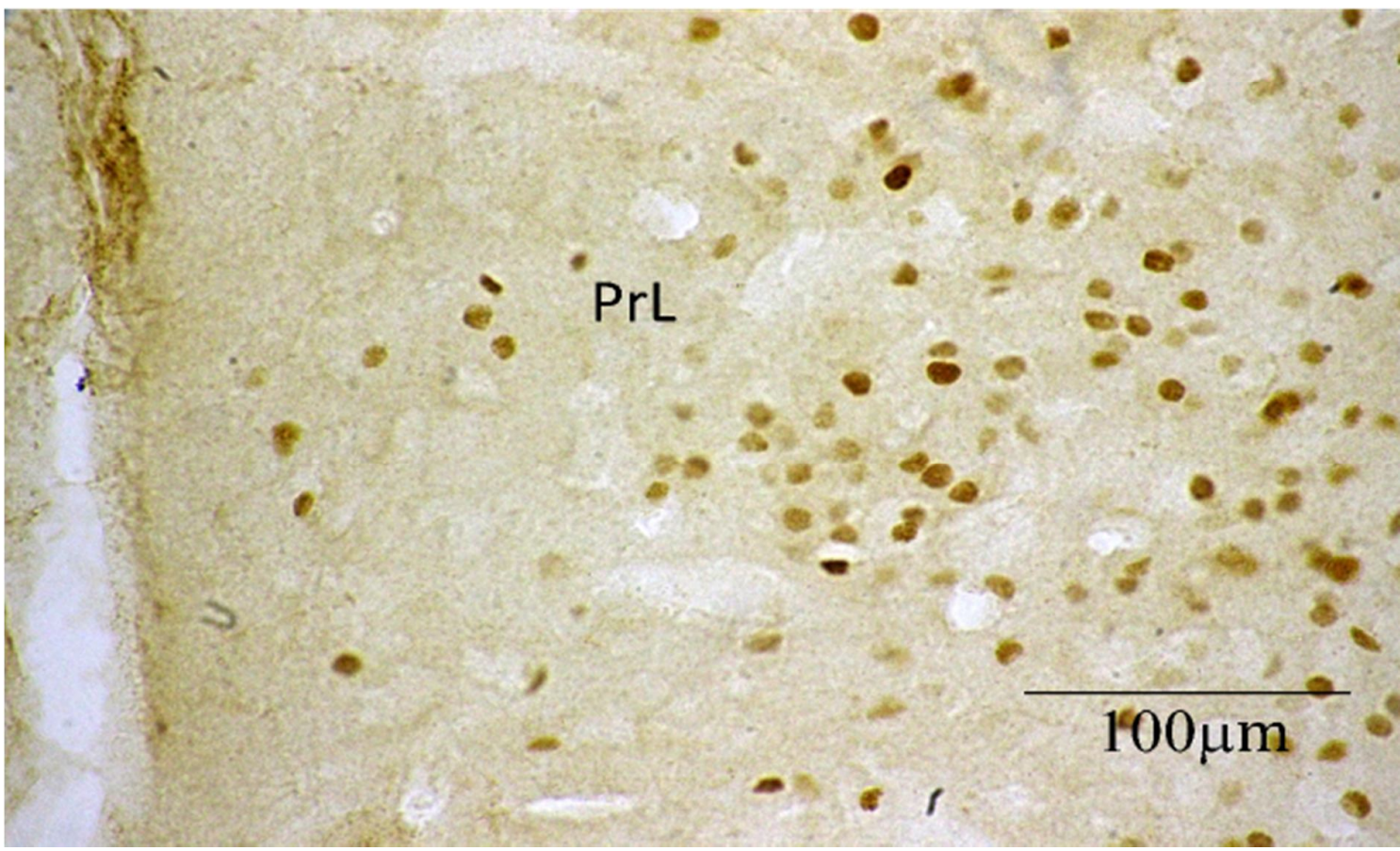

Figura 14. Fotomicrográfias de secções coronais $(40 \mu \mathrm{m})$ representativas de estruturas telencefálicas de cérebros de ratos. Ilustra-se a imunoreatividade da proteína Fos (Fos-IR). A. 100x B. 40x . Os pontos escuros marcam a expressão da proteína Fos. 
As Figuras 15, 16, 17 e 18 apresentam as médias de neurônios FOS+ em vinte estruturas encefálicas previamente asociadas com comportamentos ansiosos. A ANOVA de uma via mostrou diferencias significativas na imunorreatividade à proteina Fos no $\operatorname{PrL}\left(\mathrm{F}_{(2,20)}\right.$ $=17,924 ; \mathrm{p}<0,001), \operatorname{Cg} 1\left(\mathrm{~F}_{(2,27)}=3,416 ; \mathrm{p}<0,05\right), \operatorname{LSD}\left(\mathrm{F}_{(2,20)}=14,261 ; \mathrm{p}<0,001\right), \mathrm{PVN}$ $\left(\mathrm{F}_{(2,20)}=9,508 ; \mathrm{p}<0,001\right), \mathrm{MS}\left(\mathrm{F}_{(2,22)}=4,499 ; \mathrm{p}<0,05\right), \mathrm{GD}\left(\mathrm{F}_{(2,21)}=3,883 ; \mathrm{p}<0,05\right)$, BLA $\left(\mathrm{F}_{(2,25)}=8,473 ; \mathrm{p}<0,01\right)$ e PR $\left(\mathrm{F}_{(2,24)}=6,442 ; \mathrm{p}<0,01\right)$ e $\mathrm{LC}\left(\mathrm{F}_{(2,25)}=3,565 ; \mathrm{p}<0,05\right)$. Nas outras estruturas avaliadas (MO, IL, Cg2, M2, SH,VMH, CeA, SMM, EC, EnC, PAGd e PAGv) não foram observadas alterações significativas no número de neurônios fos+.

As análises post-hoc revelaram que no PrL os ratos CHF e CLF tiveram uma diminuição do número de neurônios marcados em comparação com os ratos da linhagem RND ( $p<0,01$ ), também foi observado que os CHF tiveram mais neurônios marcados que os CLF nesta área $(\mathrm{p}<0,05)$. No Cg1 foi visto que os CHF tiveram menos expressão da proteína FOS que os ratos CLF (p<0,05) (Figura 15.).

No LSD como observado na Figura 16 os CHF apresentaram mais atividade que os RND e os CLF (p<0,01). No PVN os CHF e os RND tiveram mais atividade que os CLF $(\mathrm{p}<0,05)$. Os CHF também apresentaram mais atividade que os RND ( $p<0,05)$. No MS e no GD os CHF apresentaram um maior número de neurônios marcados em comparaçãao com os RND. $(\mathrm{p}<0,05)$.

Na BLA (Figura 17.) os CLF apresentaram menor número de neurônios marcados que os ratos RND e CLF ( $\mathrm{p}<0,01)$. No PR os CLF apresentaram maior número de neurônios marcados que os RND e os CHF ( $\mathrm{p}<0,01$ ). Por último no LC (Figura 18) os CHF apresentaram maior número de neurônios marcados em comparacao com os CLF e RND $(\mathrm{p}<0,05)$. 
A.

MO

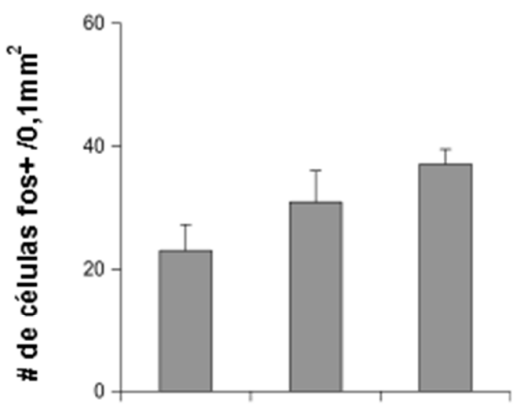

c.

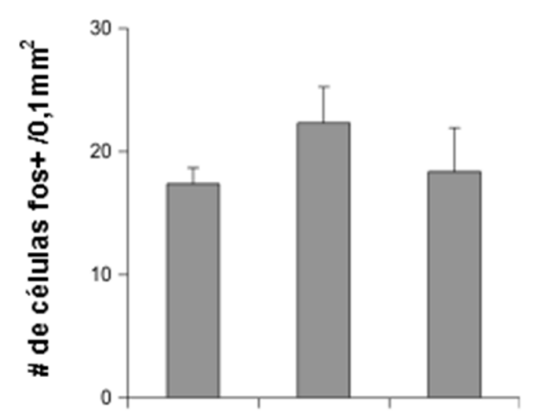

E.

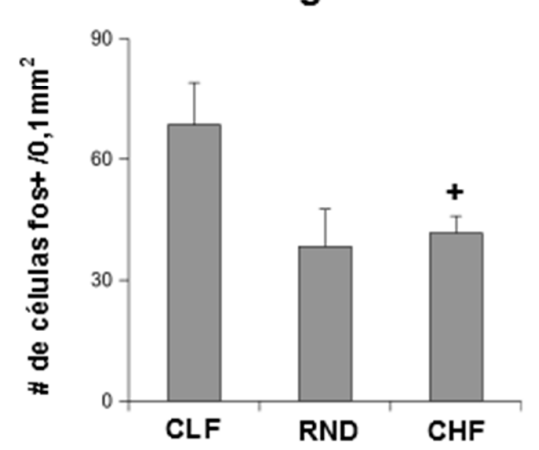

B.

PrL

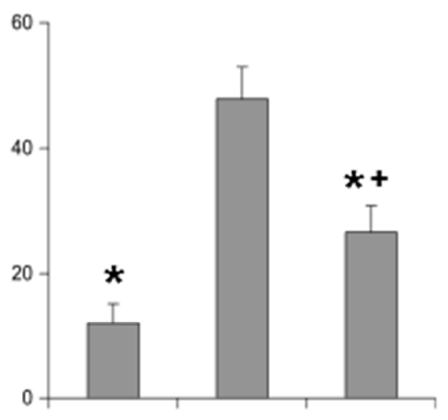

D.

Cg2

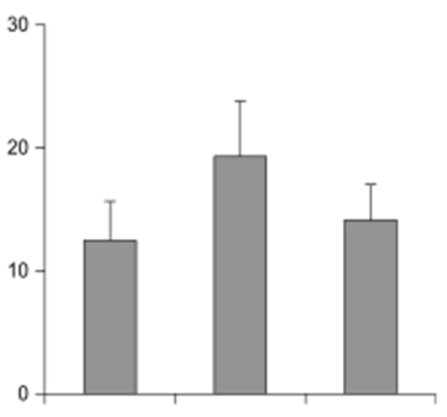

F.

M2

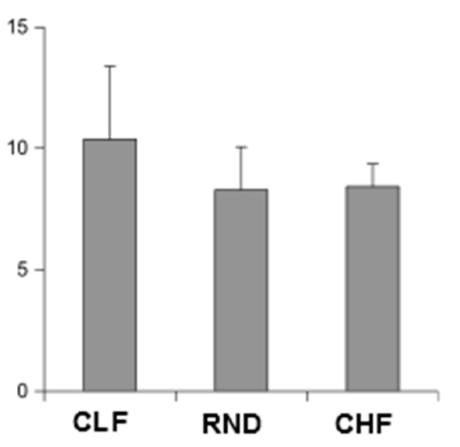

Figura 15. Histograma representativo do número de neurônios FOS imunoreativos (FOS-IR). A. Córtex orbito medial (MO), B. Córtex pré-límbico (PrL), C. Córtex Infralímbico (IL), D. Córtex Cingulado 2 (Cg2), E. Córtex Cingulado1(Cg1), F. Córtex motor secundario(M2), dos ratos RND, CLF e CHF após ser submetidos ao reteste no medo condicionado ao contexto. Os valores estão apresentados como média \pm EPM. *Diferente do grupo RND, +Diferente do grupo CLF, teste post-hoc Newman Keuls, (n=6-11). 
A.

LSD

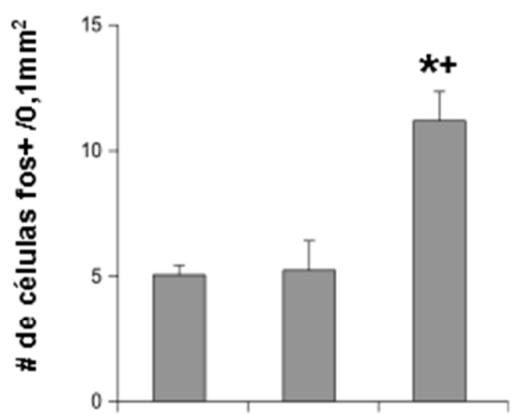

c.

SH

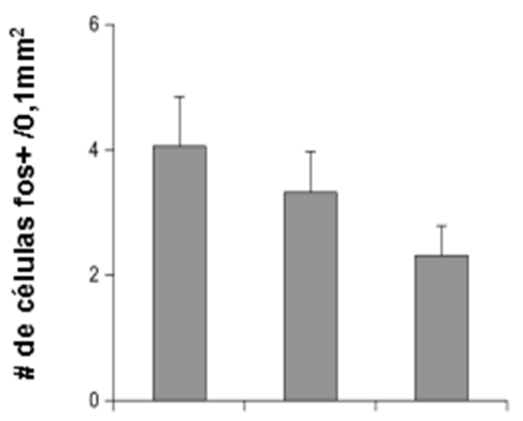

E.

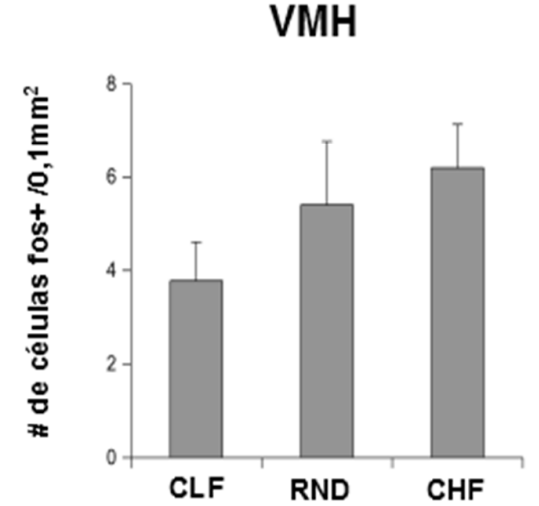

B.

PVN

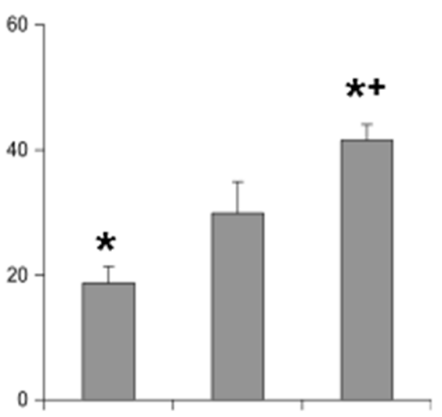

D.

MS

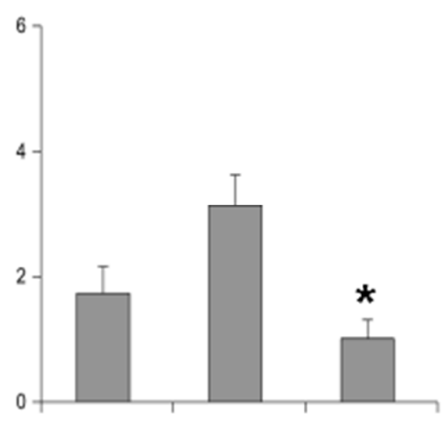

F.

GD

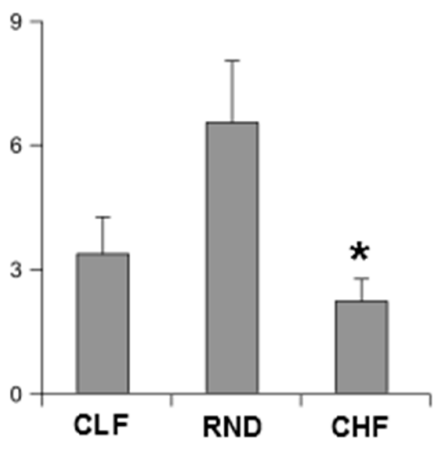

Figura 16. Histograma representativo do número de neurônios FOS imunoreativos (FOS-IR) nas estruturas. A Septum Lateral Dorsal (LSD), B. Nucleo paraventricular (PVN), C. Septum Hipocampal (SH), D. Septum medial (SM), E. Hipotalamo ventro medial (VMH), F.Giro denteado do hipocampo dorsal, dos ratos RND, CLF e $\mathrm{CHF}$ após ser submetidos ao reteste no medo condicionado ao contexto. Os valores estão apresentados como média \pm EPM. *Diferente do grupo RND, +Diferente do grupo CLF, teste post-hoc Newman Keuls, (n=6-11). 
A.

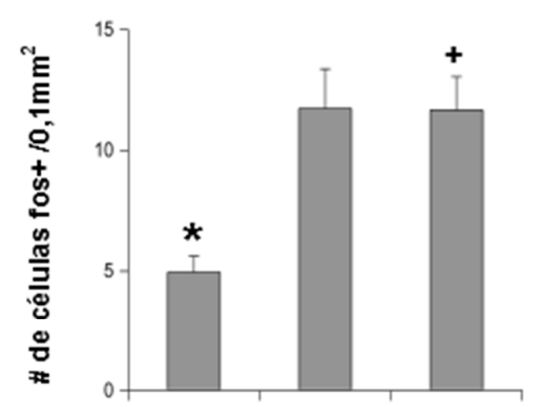

c.

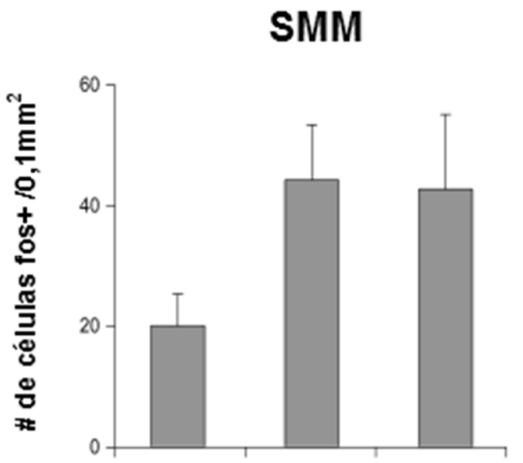

E.

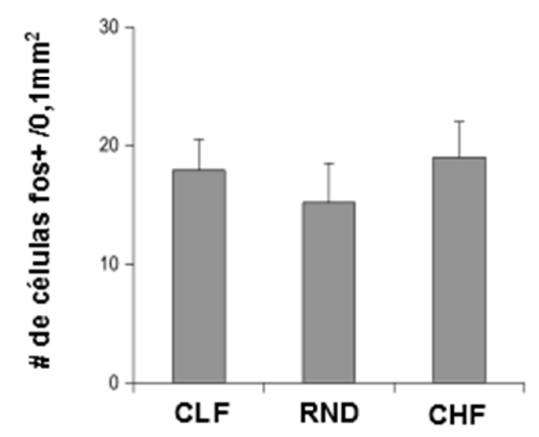

B.

CeA

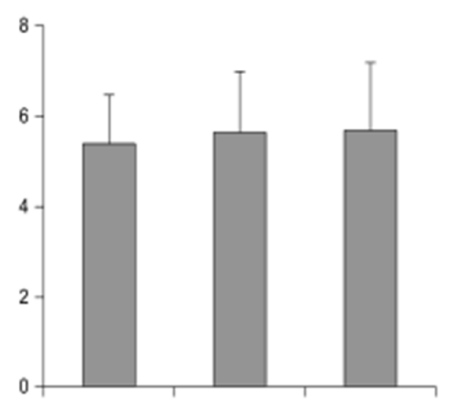

D.

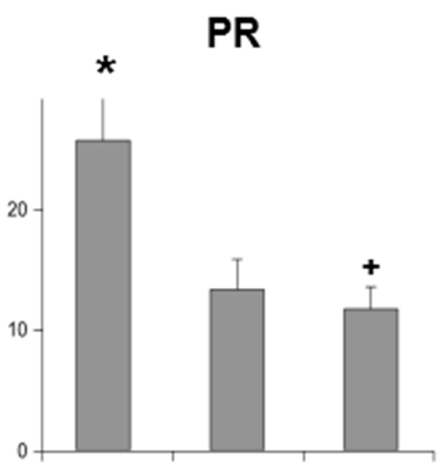

F.

EnC

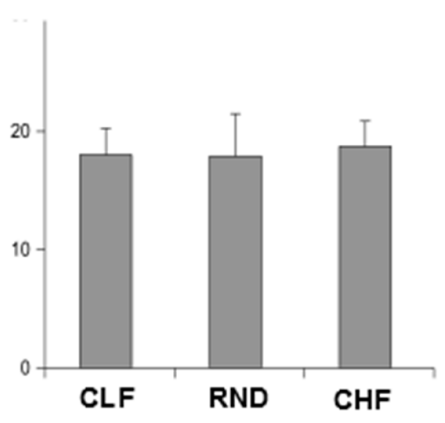

Figura 17. Histograma representativo do número de neurônios Fos imunoreativos (Fos-IR) nas estruturas telencefálicas A.Amigdala Basolateral (BLA), B. Núcleo central da Amigdala (CeA), C. Núcleo supramamilar SMM , D. Córtex Peririnal (PR), E. Córtex ectorinal (EC), F. Córtex entorinal (EnC), dos ratos RND, CLF e CHF após ser submetidos ao reteste no medo condicionado ao contexto. Os valores estão apresentados como média \pm EPM. *Diferente do grupo RND, +Diferente do grupo CLF, teste post -hoc Newman Keuls, (n=6-11). 
A.

PAGd

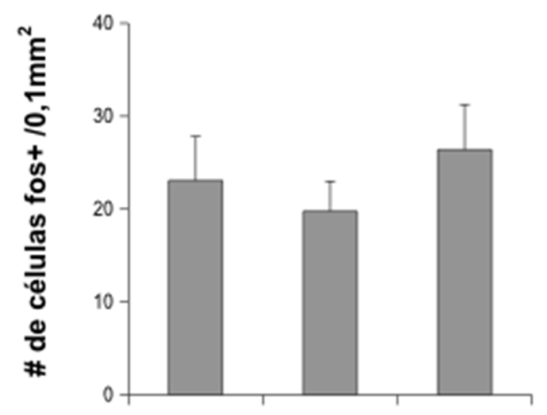

c.

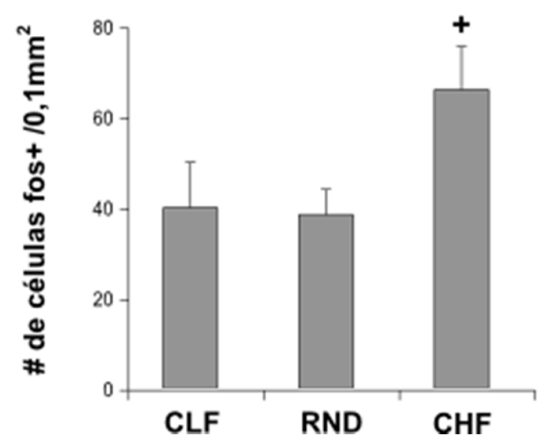

B.

PAGv

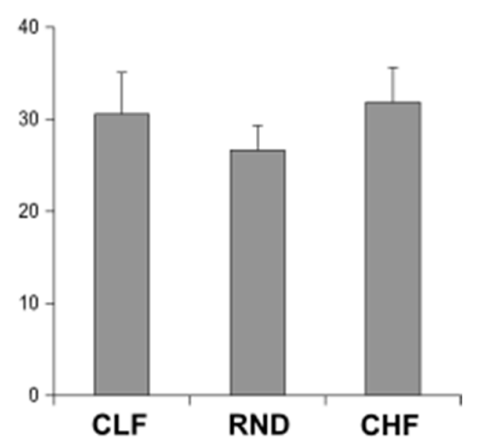

Figura 18. Histograma representativo do número de neurônios Fos imunoreativos (Fos-IR) nas estruturas telencefálicas A. Substância cinzenta periaquedutal dorsal (PAGd), B. Substância cinzenta periaquedutal ventral (PAGv), C. Locus Coeruleus (LC), dos ratos RND, CLF e CHF após ser submetidos ao reteste no medo condicionado ao contexto. Os valores estão apresentados como média \pm EPM. +Diferente do grupo CLF, teste post-hoc Newman Keuls, (n=6-11).

\subsection{Experimento 4: Efeitos do antagonista serotoninérgico 5-HT $\underline{2 A}_{2}$, ketanserina sistêmica e local nos ratos CHF, CLF e RND submetidos ao teste labirinto em cruz elevado}

Na primeira parte serão apresentadas as análises da injeção sistêmica. Na Figura 19A apresenta-se a frequência de entrada aos braços abertos. A ANOVA de duas vias mostrou diferenças significativas na frequência de entradas aos braços abertos no fator linhagem $\left(F_{(2,51)}=6,683 ; p<0,01\right)$ e na interação linhagem*tratamento $\left(F_{(2,51)}=4,351 ; p<0,01\right)$. A comparação das médias dos grupos (Student Newman-Keuls) mostrou que, quando comparados com os animais controle, os animais da linhagem CLF, que receberam veículo saíram mais aos braços abertos ( $\mathrm{p}=0,014)$, enquanto os $\mathrm{CHF}$ saíram menos em comparação com o grupo RND ( $\mathrm{p}=0,038)$ e CLF ( $\mathrm{p}<0,001)$. Da mesma forma, a análise post hoc das médias dos grupos mostrou que para os animais da linhagem CLF, aqueles que receberam ketanserina saíram menos nos braços abertos, que aqueles que receberam veículo $(p=0,020)$. 
Não se encontraram diferenças significativas no fator tratamento $\left(F_{(1,51)}=0,0811 ; p=0,777\right)$. $\mathrm{Na}$ porcentagem de entradas nos braços abertos foram encontradas as mesmas diferenças. A análise post hoc mostrou que os ratos CLF tratados com DMSO tinham uma porcentagem maior de entradas aos braços abertos, em relação com os ratos RND ( $p=0,001)$ e CHF $(\mathrm{p}=0,008)$.

No mesmo sentido não se encontraram diferenças significativas na entrada aos braços fechados como observado na Figura 19B. Porém encontram-se diferenças na porcentagem de entradas aos braços fechados correspondente com a porcentagem de entradas nos braços abertos (Figura 19D).

Em relação com a porcentagem de tempo se encontraram diferenças significativas na porcentagem de tempo nos braços aberto no fator linhagem $\left(F_{(2,51)}=6,294 ; p<0,01\right)$ e na interação linhagem*tratamento $\left(\mathrm{F}_{(2,51)}=6,971 ; \mathrm{p}<0,01\right)$. Como se mostra na Figura $19 \mathrm{E}$ a analise análise post hoc das médias dos grupos mostrou que o grupo de ratos CLF em geral permanecia mais tempo nos braços abertos que os $\operatorname{RND}(\mathrm{p}=0,026)$ e os $\mathrm{CHF}(\mathrm{p}=0,003)$. Também que os ratos CHF tratados com veículo apresentaram menor porcentagem de tempo nos braços abertos em comparação com o grupo CLF ( $p<0,001)$ e RND ( $\mathrm{p}=0,001)$. Assim também se encontraram diferenças correspondentes na porcentagem de tempo nos braços fechados. 
A.

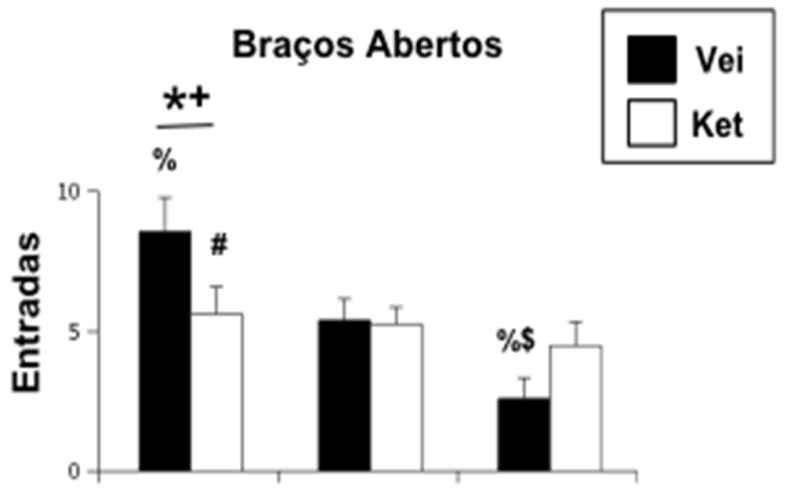

C.

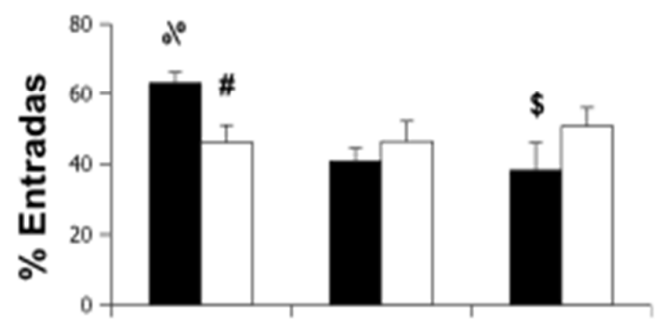

E.

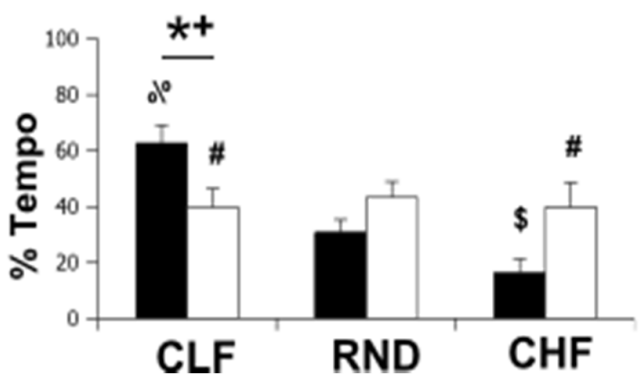

B.

\section{Braços Fechados}

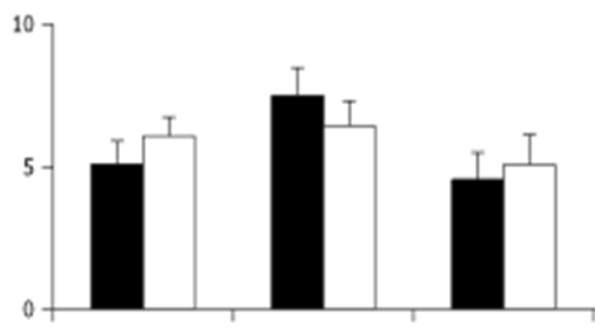

D.

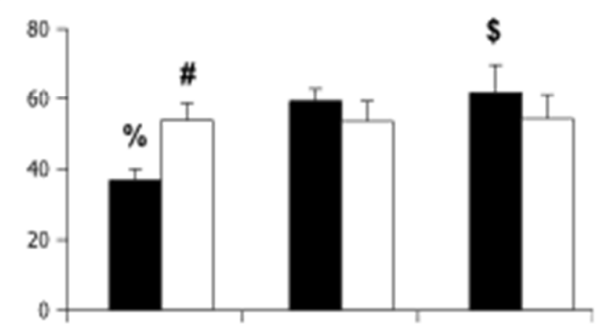

F.

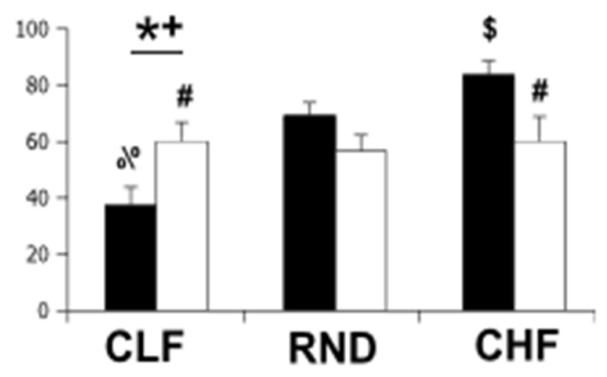

Figura 19. Efeito de Ketanserina (Ket) ou Veículo (Vei) injetada sistemicamente no comportamento explorátorio dos ratos RND, CLF e CHF após ser submetidos ao reteste no medo condicionado ao contexto. A, número de entradas aos braços abertos do laberinto; $\mathrm{B}$, número de entradas aos braços fechados; $\mathrm{C}$, porcentagem de entradas nos braços abertos; D, porcentagem de entradas nos braços fechados; E, porcentagem de tempo nos braços abertos; F, porcentagem de tempo nos braços fechados. Os valores estão apresentados como média +

EPM. *+ Diferente do grupo RND e CHF sem ter em consideração o tratamento, \% Diferente do grupo RND com o mesmo tratamento. \$ Diferente do grupo CLF com o mesmo tratamento. \#Diferente do tratamento com Vei na mesma linhagem ( $\mathrm{p}<0,05$, teste post-hoc Newman Keuls, $\mathrm{n}=7-11$ ). 
A.

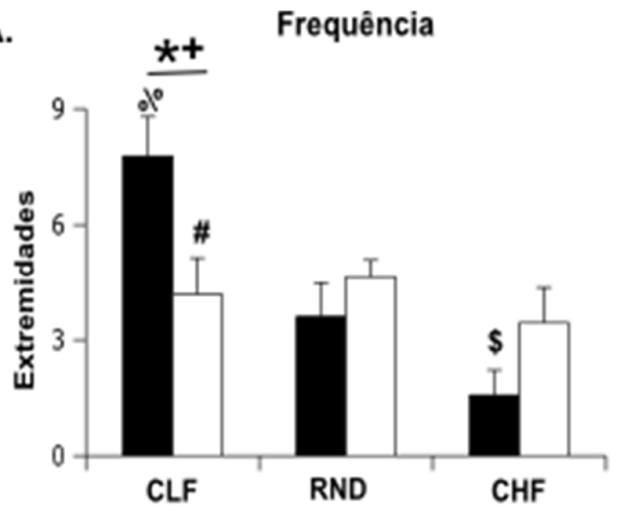

B.

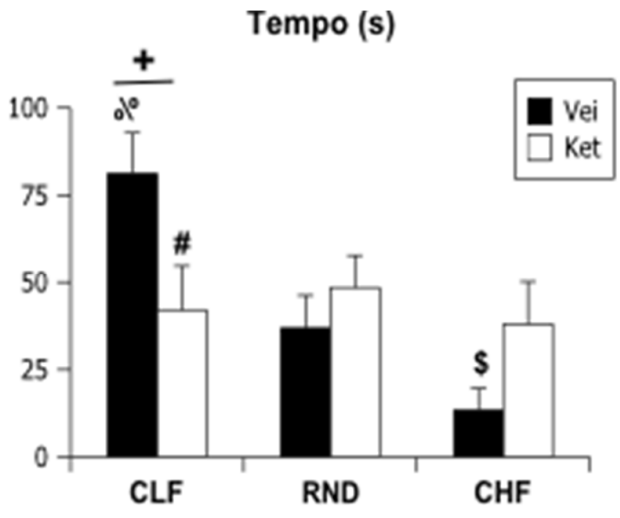

Figura 20. Efeito de Ketanserina (Ket) ou Veículo (Vei) injetada sistemicamente na frequência e tempo nas extremidades nos braços abertos dos ratos RND, CLF e CHF após ser submetidos ao reteste no medo condicionado ao contexto. A, número de entradas às extremidades dos braços abertos do laberinto; $\mathrm{B}$ tempo nas

extremidades dos braços abertos do laberinto. Os valores estão apresentados como média \pm EPM.*+ Diferente do grupo RND e CHF sem ter em consideração o tratamento, \% Diferente do grupo RND com o mesmo tratamento. \$ Diferente do grupo CLF com o mesmo tratamento. \#Diferente do tratamento com Vei na mesma linhagem ( $\mathrm{p}<0,05$, teste post-hoc Newman Keuls, $\mathrm{n}=7-11)$.

Encontraram-se também diferenças significativas na entrada nas extremidades dos braços abertos para o fator linhagem $\left(\mathrm{F}_{(2,51)}=7,847 ; \mathrm{p}=0,001\right)$, e na interação $\left(\mathrm{F}_{(2,51)}=5,984\right.$; $\mathrm{p}=0,005)$. Os CLF que receberam Vei também foram os que mais saíram às extremidades abertas em comparação com os CHF ( $\mathrm{p}<0,001)$ e RND ( $\mathrm{p}=0,027)$. Os CLF com ketanserina saíram menos que os CLF tratados com Vei às extremidades $(p=0,004)$, como se observa na Figura 20A. No tempo observam-se as mesmas diferenças correspondentes com a frequência.

Como apresentado na Figura 21A na análise comportamental os ratos apresentaram diferenças na frequência de dipping no fator linhagem $\left(\mathrm{F}_{(2,51)}=3,814 ; \mathrm{p}=0,029\right)$, mas não no fator tratamento $\left(\mathrm{F}_{(1,51)}=0,0232 ; \mathrm{p}=0,880\right)$, nem se encontrou na interação $\left(\mathrm{F}_{(2,51)}=2,958 ; \mathrm{p}=\right.$ 0,061). Os CLF apresentaram maior frequência de dipping que os CHF ( $\mathrm{p}=0,024)$ e os RND $(\mathrm{p}=0,006)$. Também se encontrou diferença na interação de fatores para tempo de dipping $\left(\mathrm{F}_{(2,51)}=4,006 ; \mathrm{p}=0,024\right)$, frequência de head out $\left(\mathrm{F}_{(2,51)}=4,886 ; \mathrm{p}=0,011\right)$ e tempo de head out $\left(\mathrm{F}_{(2,51)}=5,127 \quad ; \mathrm{p}=0,009\right)$.

Na Figura 21C se observa que os CLF que receberam Vei tiveram maior frequência de Head Out que os CHF ( $\mathrm{p}=0,001)$ e os RND $(\mathrm{p}=0,014)$ que receberam Vei. Também os CHF que receberam Ketanserina tiveram maior frequência de head out que os CHF com Vei ( $\mathrm{p}=$ 0,016). Os CLF com ketanserina tiveram menos head out que os CLF com Vei $(\mathrm{p}=0,006)$. Os CHF com ketanserina fizeram mais tempo de Head Out que os CHF com Vei $(p=0,028)$. 
A.

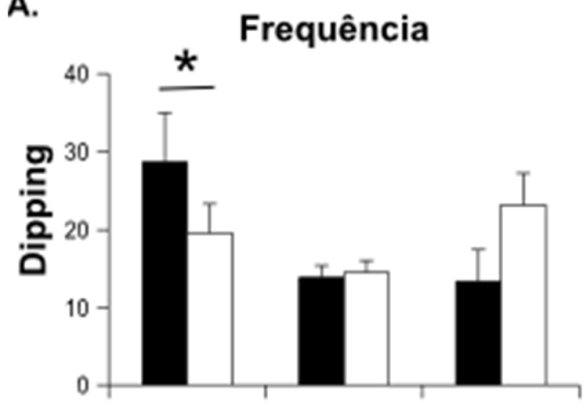

C.

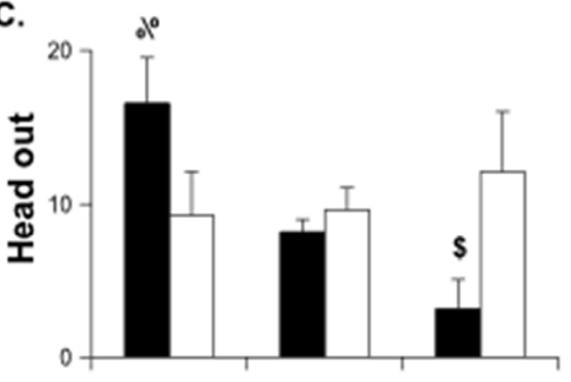

E.

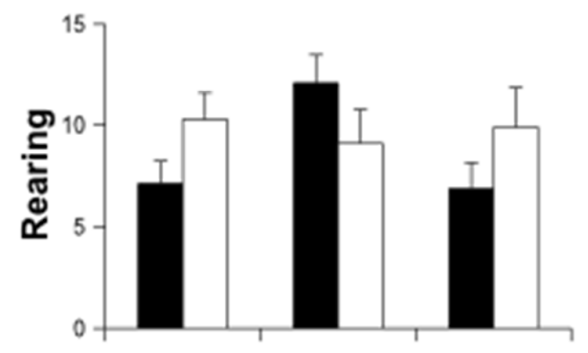

G.

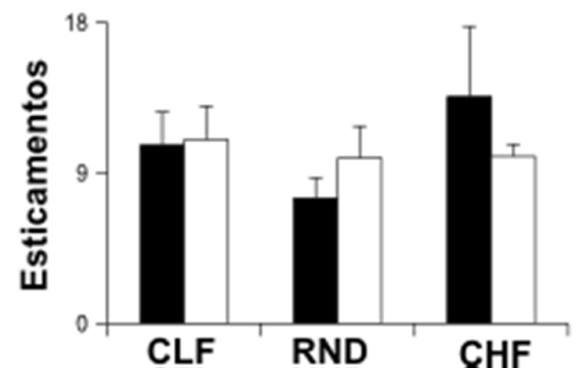

B.

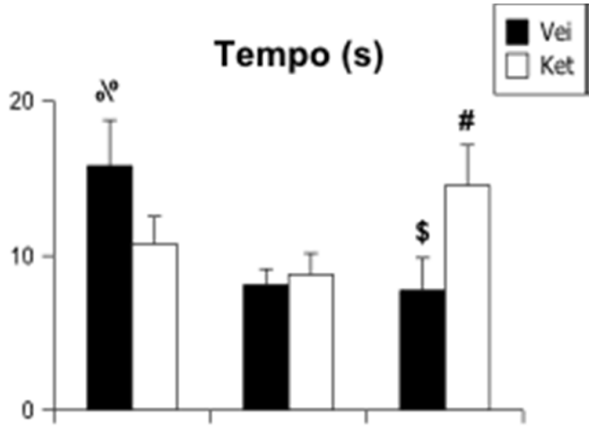

D.

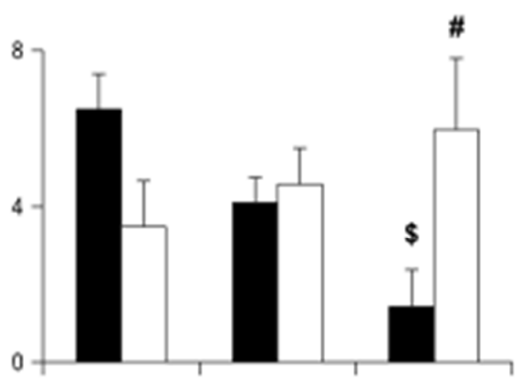

F.
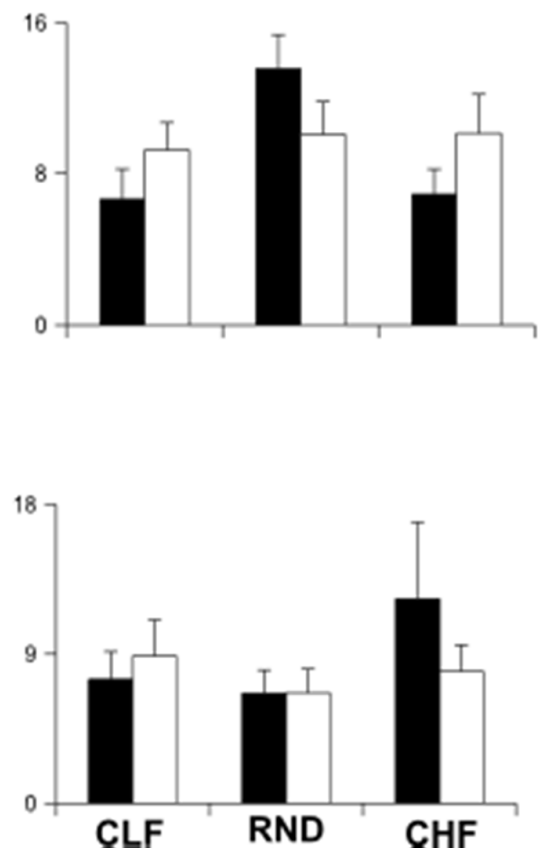

Figura 21. Efeito de Ketanserina (Ket) ou Veiculo (Vei) injetada sistemicamente nos comportamentos dos ratos RND, CLF e CHF após ser submetidos ao reteste no medo condicionado ao contexto. A, número de entradas aos braços abertos do laberinto; B, número de entradas aos braços fechados; $\mathrm{C}$, porcentagem de entradas nos braços abertos; D, porcentagem de entradas nos braços fechados; E, porcentagem de tempo nos braços abertos; F, porcentagem de tempo nos braços fechados. Os valores estão apresentados como média + EPM. *Diferente da linhagem RND sem ter em consideração o tratamento, \% Diferente do grupo RND com o 
mesmo tratamento. \$ Diferente do grupo CLF com o mesmo tratamento. \#Diferente do tratamento com Vei na mesma linhagem ( $\mathrm{p}<0,05$, teste post-hoc Newman Keuls, $\mathrm{n}=7-11)$.

Na segunda parte do experimento foi injetada ketanserina ou Veículo no córtex préfrontal especificamente o PrL, Na Figura 22 apresentam-se as medidas clássicas do LCE. Na Figura 22A podemos observar a frequência de entrada aos braços abertos. A ANOVA de duas vias mostrou diferenças significativas na frequência de entradas aos braços abertos no fator tratamento $\left(\mathrm{F}_{(2,50)}=5,498 ; \mathrm{p}<0,01\right)$ e na interação dos fatores linhagem*tratamento $\left(\mathrm{F}_{(2,50)}=\right.$ 4,351; p<0,01). A comparação das médias dos grupos (Student Newman-Keuls) mostrou que os animais da linhagem CHF, que receberam Vei saíram menos aos braços abertos em comparação com o grupo RND ( $\mathrm{p}=0,001)$ e CLF ( $\mathrm{p}<0,01)$. Da mesma forma, a análise post hoc das médias dos grupos mostrou que para os animais da linhagem $\mathrm{CHF}$, aqueles que receberam ketanserina saíram mais nos braços abertos, que aqueles que receberam Vei ( $p$ $<0,001)$.

$\mathrm{Na}$ porcentagem de entradas nos braços abertos foram encontradas as mesmas diferenças. A análise post-hoc mostrou que os ratos CLF tratados com Vei tinham uma porcentagem maior de entradas nos braços abertos em relação com os ratos RND ( $p=0,001)$ e $\mathrm{CHF}(\mathrm{p}=0,008)$

A Figura 22E ilustra a porcentagem de tempo nos braços abertos encontram-se diferenças significativas no fator linhagem $\left(\mathrm{F}_{(2,50)}=3,481 ; \mathrm{p}=0,038\right)$ e na interação tratamento*linhagem $(\mathrm{F}=5,764 ; \mathrm{p}=0,006)$. As análises post hoc revelaram que os ratos $\mathrm{CHF}$ que receberam Vei permaneciam menos tempo nos braços abertos que os $\operatorname{RND}(\mathrm{p}<0,001)$ e os CLF ( $\mathrm{p}=0,015)$. Nos animais RND foi observado um efeito da ketanserina diminuindo a porcentagem de tempo nos braços abertos $(\mathrm{p}=0,032)$ e aumentando a permanência nos braços fechados $(p=0,032)$ como observado na Figura 22F. Assim também foi observada uma diferença onde os CHF que receberam ketanserina apresentaram uma maior percentagem de tempo nos braços abertos que os $\mathrm{CHF}$ que receberam Vei $(\mathrm{p}=0,015)$. 
A.

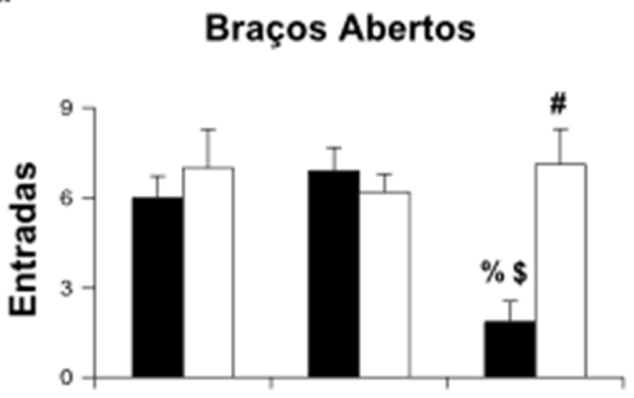

C.

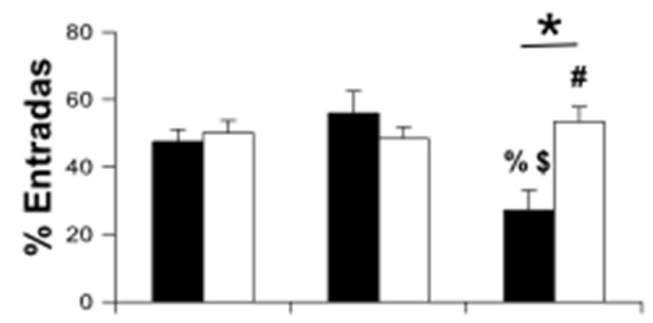

E.

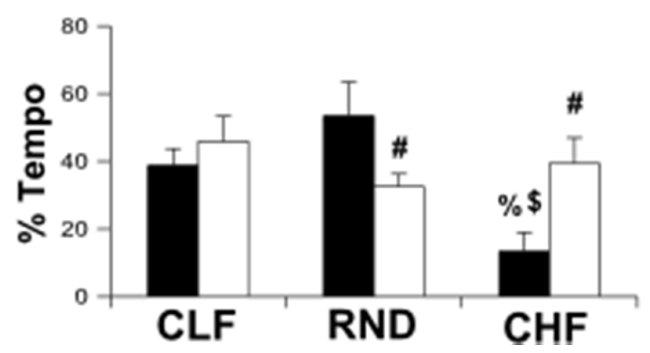

B.

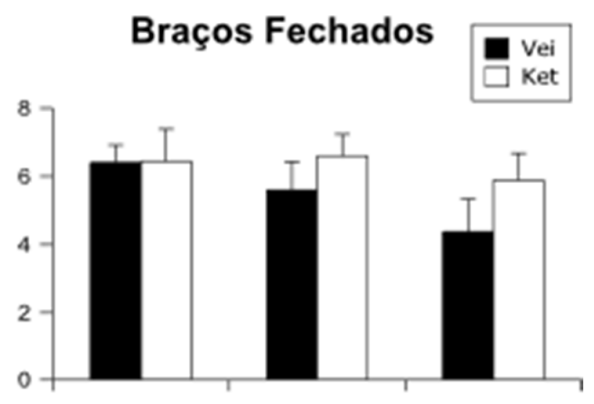

D.

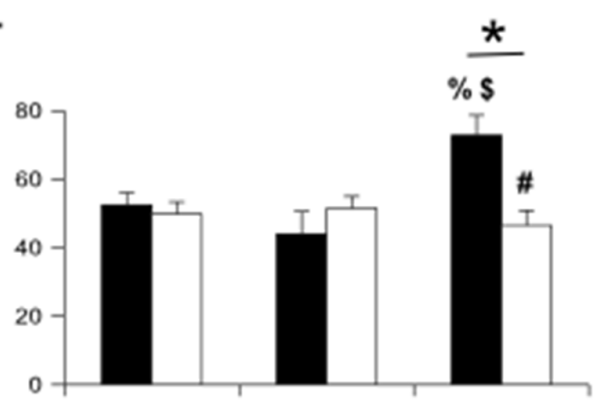

F.

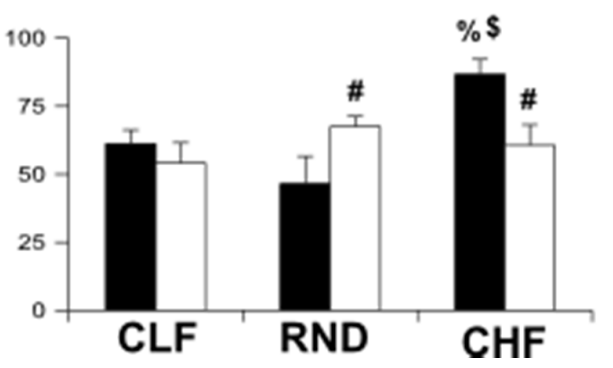

Figura 22. Efeito de Ketanserina (Ket) ou Veiculo (Vei) injetada intracerebralmente no comportamento explorátorio dos ratos RND, CLF e CHF após ser submetidos ao reteste no medo condicionado ao contexto. A, número de entradas aos braços abertos do laberinto; B, número de entradas aos braços fechados; C, porcentagem de entradas nos braços abertos; D, porcentagem de entradas nos braços fechados; E, porcentagem de tempo nos braços abertos; F, porcentagem de tempo nos braços fechados. Os valores estão apresentados como média + EPM. * Diferente do grupo RND e CLF sem ter em consideração o tratamento, \% Diferente do grupo RND com o mesmo tratamento. \$ Diferente do grupo CLF com o mesmo tratamento. \#Diferente do tratamento com Vei na mesma linhagem ( $\mathrm{p}<0,05$, teste post-hoc Newman Keuls, $\mathrm{n}=7-11)$.

Encontraram-se também diferenças significativas na entrada nas extremidades dos braços abertos para o fator tratamento $\left(\mathrm{F}_{(1,50)}=6,221 ; \mathrm{p}=0,016\right)$. Os ratos que receberam Vei também foram os que saíram menos às extremidades abertas em comparação com os tratados com Ket. No tempo foi observada uma diferença na interação dos fatores linhagem $\mathrm{x}$ tratamento $\left(\mathrm{F}_{(2,50)}=4,364 ; \mathrm{p}=0,018\right)$. Os RND tratados com Vei permaneceram mais tempo que os CLF e os CHF nas extremidades $(\mathrm{p}<0,05)$ (Figura 23). 
Frequência

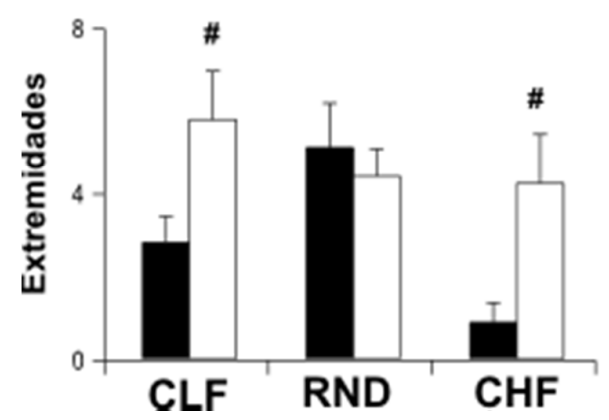

D.

Tempo (s)

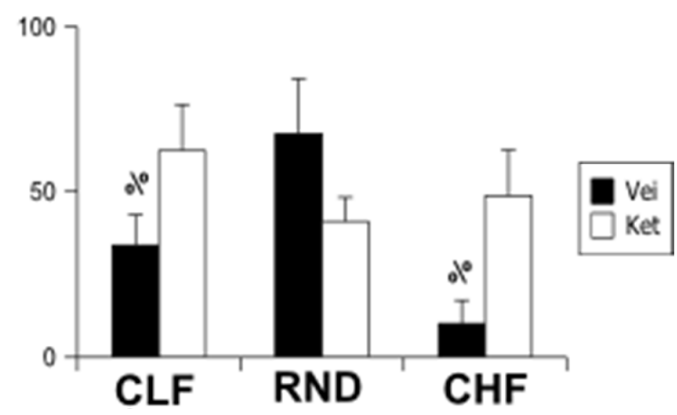

Figura 23. Efeito de Ketanserina (Ket) ou Veiculo (Vei) injetada localmente na frequência e tempo nas extremidades nos bracos abertos dos ratos RND, CLF e CHF após ser submetidos ao reteste no medo condicionado ao contexto. A, número de entradas às extremidades dos braços abertos do laberinto; $\mathrm{B}$, tempo nas extremidades dos braços abertos do laberinto. Os valores estão apresentados como média \pm EPM. \% Diferente do grupo RND com o mesmo tratamento. \#Diferente do tratamento com DMSO na mesma linhagem ( $<<0,05$, teste post-hoc Newman Keuls, n=7-11).

Como apresentado na Figura 24 na análise comportamental os ratos não apresentaram diferenças na frequência de dipping no fator linhagem $\left(\mathrm{F}_{(2,50)}=1,804 ; \mathrm{p}=0,175\right)$, nem no fator tratamento $\left(\mathrm{F}_{(1,50)}=3,397 ; \mathrm{p}=0,071\right)$, porém foram encontradas diferenças na interação $\left(\mathrm{F}_{(2,50)}\right.$ $=7,734 ; \mathrm{p}=0,001)$. Os CHF tratados com ketanserina apresentaram maior frequência de dipping que os CHF tratados com veiculo $(\mathrm{p}<0,001)$ e os RND. Dos ratos tratados com ketanserina, os RND apresentaram menor frequência de dipping que os CLF ( $\mathrm{p}<0,01)$ e os CHF ( $\mathrm{p}<0,01)$.

Também se encontrou diferença no fator tratamento $\left(F_{(1,50)}=6,434 ; p=0,014\right)$ e na interação de fatores para frequência de head out $\left(\mathrm{F}_{(2,50)}=6,320 ; \mathrm{p}=0,004\right)$. Assim, os ratos tratados com ketanserina apresentavam maior frequência de head out que os tratados com Vei. Também se observa que os ratos RND tratados com ketanserina tiveram uma frequência menor de head out que os ratos CLF $(\mathrm{p}=0,001)$ e CHF $(\mathrm{p}=0,001)$. e os RND $(\mathrm{p}=0,014)$ que receberam Vei.

No tempo de head out os CHF apresentaram menor tempo que os CLF $(\mathrm{p}=0,012)$ e os RND ( $\mathrm{p}=0,001$ ). Na frequência e no tempo de Rearing foi observado um efeito do tratamento, onde os ratos tratados com Ketanserina apresentaram um aumento em comparação com os tratados com Vei $\left(\mathrm{F}_{(2,50)}=4,077 ; \mathrm{p}=0,049\right)$. 
A.

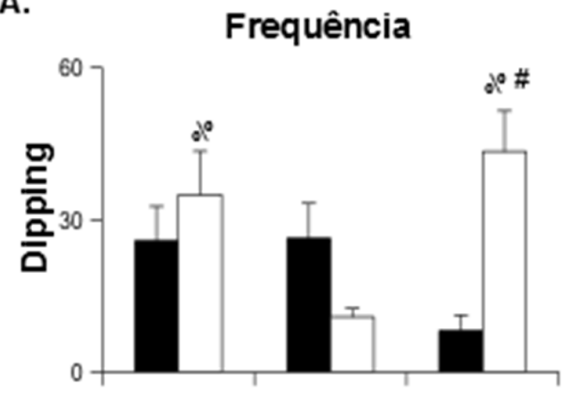

C.

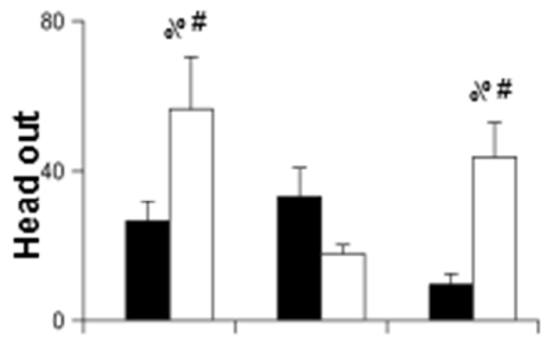

E.

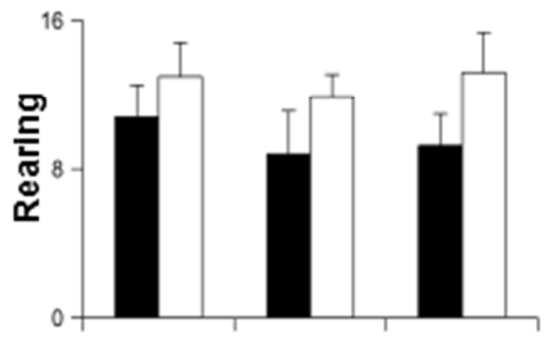

G.

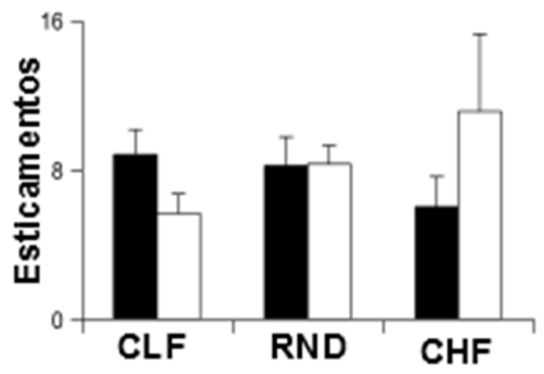

B.

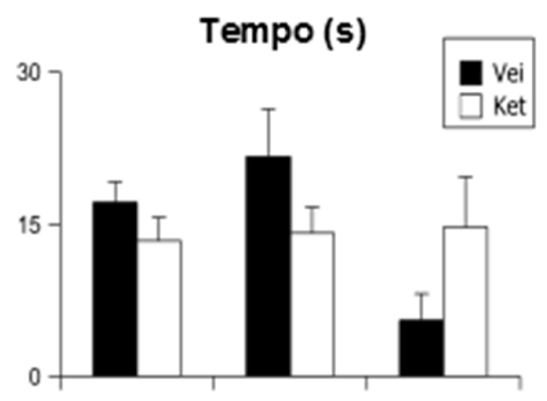

D.

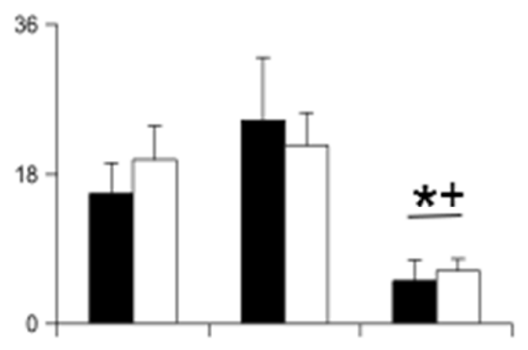

F.

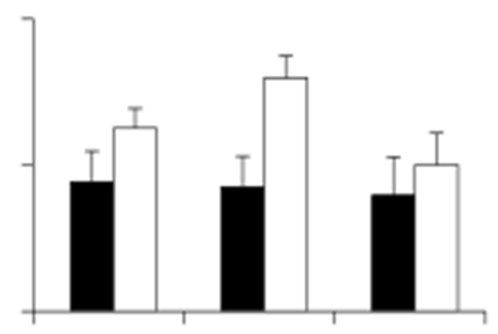

H.

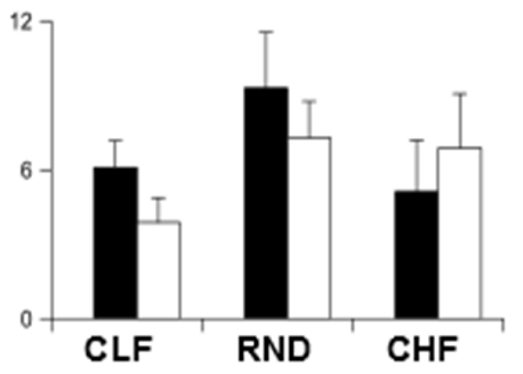

Figura 24. Efeito de Ketanserina (Ket) ou Veiculo (Vei) injetada localmente no córtex pré-límbico nos comportamentos dos ratos RND, CLF e CHF após ser submetidos ao reteste no medo condicionado ao contexto. A, número de entradas aos braços abertos do labirinto; B, número de entradas aos braços fechados; C, porcentagem de entradas nos braços abertos; D, porcentagem de entradas nos braços fechados; E, porcentagem de tempo nos braços abertos; F, porcentagem de tempo nos braços fechados. Os valores estão apresentados como média + EPM. *+ Diferente do grupo RND e CHF sem ter em consideração o tratamento, \% Diferente do grupo RND com o mesmo tratamento. \$ Diferente do grupo CLF com o mesmo tratamento. \#Diferente do tratamento com DMSO na mesma linhagem ( $\mathrm{p}<0,05$, teste post-hoc Newman Keuls, $\mathrm{n}=7-11$ ). 


\section{Discussão}

Os investigadores têm encontrado, de forma sistemática, que uma maior susceptibilidade ao estresse, em animais, pode levar ao desenvolvimento de um amplo espectro de psicopatologias. Embora a proporção de animais que realmente desenvolve os sintomas devido ao estresse varie entre 15\% a 85\% (SHERMAN; PETTY, 1980; PETTY et al., 1994) dependendo do protocolo experimental ou linhagem de rato (WIELAND et al., 1986), sexo e outros fatores como a manipulação ou temporada do ano, encontrar um substrato neuroquímico para essa vulnerabilidade ao estresse é de grande interesse teórico e clínico.

A vulnerabilidade ao estresse é um fator de risco importante para desenvolver patologias como transtornos de ansiedade e depressão (SANDI; BISAZ, 2007; AISA et al., 2008; UCHIDA et al., 2008; CASTRO et al., 2010). Em trabalhos anteriores, mostramos que o mesmo tratamento farmacológico (MDMA ou fluoxetina) conduziu a efeitos opostos, dependendo da pré-exposição ou não a estresse crônico variado (também chamado de estresse crônico inescapável), o que sugere efeitos diferenciais da droga, como dependente das condições basais do animal (LEON; LANDEIRA-FERNANDEZ; CARDENAS, 2009). Também se sabe que, na prática, nem todas as pessoas e animais não humanos respondem da mesma forma aos mesmos eventos estressores. Os fatores genéticos e ambientais têm sido envolvidos nestas diferenças na susceptibilidade (CHARNEY, 2004; SANDI; RICHTERLEVIN, 2009; FEDER; NESTLER; CHARNEY, 2009; CASTRO et al., 2012). Nossos resultados apoiam este fato, sugerindo que as diferenças na resposta ao estresse podem estar relacionadas em parte com o fenótipo e o genótipo (por seleção fenotípica consecutiva). Por esta razão, o mesmo estímulo pode desencadear comportamentos e respostas hormonais diferentes.

O fator genético e a historia de vida ajudam na construção de "traits" (traços) de personalidade (KALISCH et al., 2004; INDOVINA et al., 2011; CASTRO et al., 2012). Estes resultados indicam que as condições basais anteriores aos experimentos têm um impacto forte na resposta comportamental e neuroendócrina na presença de um evento estressante. Isto é importante no momento de fazer experimentos comportamentais para aumentar a precisão dos tratamentos farmacológicos e reduzir a variabilidade. Assim como também entender os mecanismos envolvidos nas diferentes respostas aos mesmos estímulos.

No presente projeto, o nosso principal objetivo foi o de avaliar a vulnerabilidade dos ratos das linhagens CHF, CLF e RND ao desenvolvimento de comportamentos associados com 
ansiedade. Além disto, nós também avaliamos alterações neurobiológicas dos animais após a exposição a situações aversivas ou estressoras, tais como o medo condicionado ao contexto e a contenção. Finalmente, avaliamos também o comportamento das linhagens submetidas a um teste de ansiedade inata- o LCE- após o tratamento com um fármaco antagonista de receptores $5-\mathrm{HT}_{2 \mathrm{~A}}$.

Segundo Landgraf e Wigger (2003), isto é importante, pois um fenótipo de medo/ ansiedade deveria também apresentar aspectos relacionados a comportamentos, estratégias de coping (enfrentamento) e parâmetros neuroendócrinos característicos dessas condições.

Pesquisas anteriores do nosso grupo foram centradas somente nos animais que apresentam níveis altos de ansiedade, mas no presente trabalho quisemos também avaliar o outro extremo; animais que não apresentam a resposta típica de ansiedade visando encontrar caraterísticas de populações resilientes na presença de eventos estressantes.

No mesmo sentido, neste trabalho utilizamos ratos que são selecionados pela intensidade da resposta de congelamento. O congelamento é uma das respostas principais quando os ratos são recolocados no contexto onde receberam previamente choques nas patas e parece ser uma maneira efetiva de evitar um perigo potencial (OLIVEIRA et al., 2007; BRANDÃO et al., 2008).

No Experimento 1, nosso objetivo foi investigar diferenças basais no perfil hormonal entre as linhagens, tendo certeza que pertencem a um grupo que apresenta alto(CHF) ou baixo(CLF), congelamento condicionado. Além disso, também avaliamos as mudanças na resposta hormonal de corticosterona 20 minutos após um evento de estresse agudo, utilizando o condicionamento aversivo como gatilho desta resposta.

Foi possível observar que antes de serem submetidos ao estresse, na habituação, os ratos das linhagens CHF e CLF não apresentam diferenças no congelamento em relação aos ratos Wistar RND. Isto é relevante, já que indica que os ratos CHF não apresentam uma inibição comportamental espontânea e dessa maneira, quando expostos a situações estressantes, existe a ativação de mecanismos de coping (enfrentamento ao estresse), que explicariam as mudanças comportamentais subsequentes.

Dois meses após a primeira exposição ao evento aversivo (treino) foram observadas diferenças nas concentrações basais de corticosterona entre os CHF e os outros dois grupos, o que sugere diferenças também no perfil neuroendócrino que podem conduzir à resposta diferencial ao estresse. 
A manutenção do congelamento nos ratos CHF no período de exposição ao contexto previamente associado a choques elétricos nas patas pode ser explicada, pelo menos em parte, pelas altas concentrações basais de corticosterona nestes animais. Brinks et al. (2008) observaram duas linhagens diferentes de camundongos C57BL/6J e BALB/c que apresentam diferenças na formação e na extinção de memórias aversivas. Os BALB/c tem um aumento significativo de liberação de corticosterona após o treinamento e na extinção em quanto os C57BL/6J não. Os autores propuseram que sendo que os glicocorticoides modulam o processamento de estímulos aversivos, a reatividade ao estresse, observada no aumento de glicocorticóides, é essencial na formação de memórias aversivas (BRINKS; DE KLOET; OITZL, 2008). Isto é coerente com a manutenção do nível alto de congelamento apos dois meses no caso dos animais CHF.

Diferenças na concentração plasmática de corticosterona em ratos selecionados já foram observadas anteriormente. Gentesch et al. (1981) avaliaram ratos Roman High Avoidance (RHA, Romana alta esquiva) e Roman Low Avoidance (RLA, Romana baixa esquiva) selecionados na tarefa de esquiva de duas vias. Esses ratos são derivados da linhagem Sprague-Dawley. Também têm sido reportados ratos Naples High-and Low Exitability (NHE, NLE) selecionados pela ativação emocional frente à novidade e ratos Spontaneus Hypertensive Rats (SHR) e Normotensive controls (WKY). Os ratos NLE, RHA e SHR mostraram um menor aumento da concentração de corticosterona que os seus próprios grupos controle, imediatamente após ser submetidos ao teste do campo aberto, porém não se encontraram diferenças na linha de base como encontradas entre as CHF, CLF e RND.

Nossos resultados indicam que ratos CHF apresentam maiores concentrações de corticosterona tanto basais quanto após o estresse, que os CLF e RND. Esta resposta se correlaciona com a medida comportamental de congelamento. Isto também foi visto em um estudo com as linhagens RHA e RLA. Os ratos RLA (o grupo com comportamentos mais ansiosos) tiveram após a exposição à novidade, um aumento significativo de corticosterona e ACTH em comparação com os ratos RHA e essa diferença foi mantida de 20 a 50 minutos após. Porém elas não apresentaram diferenças nas amostras basais (CARRASCO et al., 2008). Deve ser levado em consideração, que os ratos que utilizamos nos nossos experimentos são ratos que já passaram por um procedimento estressante, no processo de fenotipagem da própria linhagem. Isto poderia explicar a diferença na linha de base. A exposição ao estresse pode modificar os mecanismos subjacentes ao coping e desregular o comportamento do eixo HPA. Numa revisão, Darnaudery e Maccari (2008), mostraram evidencias de que o estresse 
pré-natal pode ser capaz de modificar a programação epigenética afetando assim a resposta neuroendócrina. Mais ainda, os estudos revisados mostram que os glicocorticoides maternos na gestação também têm um papel importante no desenvolvimento do eixo HPA assim como a modulação do comportamento materno. Considerando que os ratos CHF e CLF são filhos de mães CHF e CLF, respectivamente, alterações no comportamento materno e na forma como funciona o eixo delas fazem uma importante contribuição aos efeitos a longo prazo nos filhotes e os seus mecanismos epigenéticos. No mesmo sentido, Neumann et al. (1998) avaliaram as concentrações de corticosterona em fêmeas grávidas de uma linhagem selecionada pelo comportamento no LCE e notaram uma alta concentração nos ratos mais ansiosos, quando comparados ao grupo de baixa ansiedade. Isto sugere uma constituição de fatores epigenéticos para a deflagração do endofenótipo ansioso ou não das linhagens CHF e CLF. No entanto, futuros estudos são necessários para avaliar esta possibilidade.

Segundo Landgraf e Wigger (2003), uma ativação maior do eixo HPA em ratos selecionados pelo alto comportamento ansioso no LCE sugere que esses animais são mais vulneráveis a um mesmo estímulo tendo preferencia para fazer avaliações "negativas". Piazza et al (1996) testaram a diferencia na reatividade aos glicocorticoides em ratos selecionados. Os ratos classificados como muito responsivos (HR) e pouco responsivos (LR) testados no teste novel object (objetos novos), um modelo utilizado na avaliação do comportamento ansioso e da memória. Neste experimento, ratos de ambas linhagens receberam uma injeção intraperitoneal de corticosterona. Os ratos HR apresentaram um aumento na locomoção e um aumento na liberação de dopamina no núcleo accumbens quando comparados com os animais LR e os injetados com Salina, sendo assim mais reativos aos efeitos dos glicocorticoides. De forma semelhante, nossos resultados indicaram que nos ratos CLF não foram observadas diferenças significativas antes e após o estresse, sugerindo pouca reatividade do eixo HPA nesse grupo de animais.

Em diversas pesquisas em humanos e outros animais o aumento da ativação desse eixo tem-se relacionado com alguma patologia (DE JONG; DE KLOET, 2004; AGUILARVALLES et al., 2005; BHATIA; TANDON, 2005; BREMNER, 2006; AISA et al., 2007; CARRION; WEEMS; REISS, 2007).

Resultados obtidos com sujeitos humanos corroboram a influencia de fatores hormonais no bem-estar mental. Por exemplo, Lindfors e Lundberg (2002) fizeram uma pesquisa na qual avaliaram o bem estar psicológico de adultos jovens humanos, medindo a concentração 
plasmática de corticosterona ao longo do dia. As pessoas foram divididas em dois grupos: aquelas com pontuações altas de "bem estar" psicológico e aquelas com pontuações baixas. As concentrações plasmáticas de corticosterona foram diferenciais e o grupo com pontuações altas de bem estar psicológico apresentaram concentrações significativamente menores que o grupo com pontuações altas.

Nossos resultados são coerentes com tais resultados, pois o perfil neuroendócrino basal parece predizer a resposta de congelamento apresentada no modelo de medo condicionado. Mais ainda, considerando o grupo RND, podemos observar que a resposta diante do modelo de medo condicionado ao contexto foi mantida depois de dois meses, indicando um forte componente mnemônico deste tipo de aprendizagem A resposta comportamental ao medo condicionado se apresenta mais estável nos animais CLF, sendo o mesmo observado na resposta hormonal, já que não foram encontradas diferenças significativas nem antes e nem após o estresse. Isto sugere uma maior regulação emocional de estruturas telencefálicas como a amigdala. Sabe-se que esta estrutura possui um papel primordial na circuitaria da resposta de medo condicionado. Além disto, a amígdala também se encontra envolvida na mediação das respostas fisiológicas e comportamentais ao estresse, devido a seu papel na regulação da liberação de ACTH pelas conexões que possui com o hipotálamo. Com efeito, sabe-se que a sua lesão bloqueia os efeitos dos glicocorticóides injetados sistemicamente ou intrahipocampo (KOOB; HEINRICHS, 1999; ROOZENDAAL; MCEWEN; CHATTARJI, 2009).

Porém é importante mencionar que os corticosteroides por si só não regulam o comportamento. Eles induzem mudanças químicas nos grupos neuronais associados com memória e emoção. Atuam facilitando a adaptação comportamental tendo efeito sobre a consolidação e potenciação do medo ou a facilitação da extinção da esquiva, porquanto após um evento estressante é importante que o animal lembre e possa predizer a ocorrência e o contexto de um evento aversivo (KORTE, 2001). Entretanto, como já mencionados anteriormente, diversos experimentos têm mostrado que não todos os animais reagem de forma similar aos mesmos estímulos estressantes. Liebsch et al. (1998) com linhagens derivadas de ratos Wistar, selecionados pelo comportamento apresentado no LCE, chamadas "high anxiety-related behaviour (HAB)" e "low anxiety-related behaviour (LAB)" mostraram que existe uma grande relação entre a avaliação emocional de um evento estressante e a estratégia que o animal utiliza para controlar a situação. O comportamento não é simplesmente regulado pelas demandas do ambiente, mas também pelas respostas antecipatórias. Essa regulação feed-forward para conseguir a allostasis parece estar apenas 
parcialmente, relacionada com os corticosteroides (SCHULKIN; MCEWEN; GOLD, 1994; SCHULKIN; GOLD; MCEWEN, 1998).

Mudanças na concentração de corticosterona também têm sido relacionadas com os efeitos sobre a proliferação celular no cérebro e sobre a neurogênese. Existem reportes de que a exposição ao estresse reduz a neurogênese adulta e esse efeito parece estar mediado pelo aumento da concentração de corticosterona. Oomen et al. (2007) demonstraram que com a injeção do fármaco mifepristona, um bloqueador do receptor glicocorticoide, se normalizam os efeitos negativos do estresse crônico na neurogênese mas o fármaco não apresenta um efeito por ele mesmo.

Consistente com a observação de que animais CHF e CLF apresentaram divergentes concentrações de corticosterona antes e após a exposição a uma situação de estresse agudo, nós avaliamos, no Experimento 2, a proliferação celular e a neurogênese em ratos das três linhagens (CHF, CLF e RND) submetidos ou não a restrição motora e a um protocolo de estresse crônico variado.

Banasr et al (2007) encontraram que a exposição a estresse crônico variado de ratos Sprague-Dawley durante 15 dias diminuiu significativamente (próximo ao 35\%) a proliferação celular (glia especificamente) no neocórtex utilizando os marcadores KI67 e BrdU. No presente trabalho analisamos a proliferação celular e a neurogênese no hipocampo dorsal, levando em consideração o envolvimento dessa porção hipocampal na modulação das respostas ansiosas principalmente associadas ao medo condicionado. Nosso objetivo foi pesquisar o impacto do estresse crônico variado e a restrição motora no processo de proliferação celular e neurogênese em animais de cada uma das linhagens.

Encontramos que os ratos CHF apresentam uma menor proliferação celular, independente da exposição ao estresse crônico. Contrario a isso estudos de Sandi et al (2008) mostraram que diferenças individuais no traço de ansiedade estão relacionadas com um impacto negativo, menos neurogênese, associada com exposição a estresse crônico. Porém como foi mencionado, os ratos utilizados nos nossos experimentos são ratos fenotipados através de uma situação aversiva de choque nas patas, o que pode ter influenciado na diminuição dessa proliferação. Trabalhos paralelos feitos no nosso laboratório não encontraram diferenças na proliferação em ratos CHF e CLF que não passaram pelo procedimento de fenotipagem e não foram expostos a nenhum tipo de estresse. Isto pode ser relacionado com os achados de Tanapat et al (2001) que analisaram a proliferação celular com BrdU e viram que uma única exposição ao odor de raposa diminuiu o número de células em proliferação no giro denteado. 
Este efeito foi dependente do aumento de glicocorticoides induzido pelo estresse, pois a exposição ao odor da raposa resultou num aumento da concentração de corticosterona plasmática e a prevenção desse aumento (por meio de adrenalectomia) bloqueou a diminuição da proliferação celular. Neste sentido, nossos resultados sugerem que os níveis elevados de corticosterona podem estar modulando a baixa proliferação celular hipocampal em ratos do grupo CHF. É possível também que o estresse não tenha podido diminuir ainda mais o nível de proliferação de forma semelhante à ausência de efeito sobre as já elevadas concentrações de corticosterona.

Ao analisar os neurônios imaturos no giro denteado com a marcação de DCX foi possível ver um efeito principal do estresse; aqueles animais submetidos ao estresse apresentaram menor número de neurônios imaturos. Jayatissa et al (2008) observaram o mesmo resultado em ratos expostos a duas semanas de estresse crônico variado. Encontraram uma diminuição significativa $(22,4 \%)$ no número total de células granulares nos ratos estressados observado com o marcador DCX. Entretanto, essa queda foi revertida nos ratos tratados com escitalopram que tiveram resposta positiva ao tratamento, mas não naqueles que não responderam ao fármaco, mostrando assim uma diferenciação nas mudanças estruturais causadas pelo estresse, assim como o envolvimento desses novos neurônios na modulação das respostas de estresse. No nosso estudo, o grupo mais afetado com a diminuição de neurônios imaturos foi o grupo CHF submetido ao protocolo de estresse crônico variado e restrição motora, o que sugere que os neurônios dos CHF's podem ser mais "susceptíveis" aos efeitos deletérios do estresse. Corroborando esses resultados Lucassen et al (2009) mostraram que o estresse pré-natal reduz a proliferação e a neurogênese pós-natal em ratos criados e separados seletivamente por apresentar alta ansiedade (ratos HAB selecionadas pelo comportamento ansioso no LCE). O número de células recém-geradas no hipocampo foi significativamente menor nos ratos $\mathrm{HAB}$ aos 43 dias de idade que nos LAB (selecionados por baixa ansiedade). O estresse pré-natal reduziu também o número de neurônios recém-gerados (marcados para doublecortina - DCX) apenas em ratos HAB o que é um forte indicativo da neurogênese reduzida. Segundo Lehner et al (2009) a diminuição de neurônios que têm receptores GR impede o controle inibitório do hipocampo no eixo HPA o que ocasiona um incremento na liberação de glicocorticoides em longo prazo. Em um estudo paralelo, ainda em andamento, estamos avaliando a liberação de corticosterona antes e após o estresse crônico.

Castro et al (2010) mostraram que existe uma relação de U invertida entre ansiedade e sobrevivência neuronal com os extremos de alta e baixa ansiedade associados com baixos níveis de sobrevivência de células novas comparados com níveis intermediários de ansiedade. 
Porém, nos nossos resultados isso não foi observado para os ratos CLF que não apresentaram diminuição nem na proliferação nem no número de neurônios imaturos. Isto sugere que mudanças na neurogênese não conseguem (pelo menos na linhagem investigada na presente tese) explicar o comportamento anti-aversivo ou pouco ansioso frente ao estresse.

Assim, observamos que ratos da linhagem CHF apresentam características específicas na resposta do eixo HPA, o que pode estar sendo mediado tanto pela produção reduzida de células novas no hipocampo quanto pela susceptibilidade dos novos neurônios a eventos ambientais estressantes. Tais resultados levaram-nos a supor que as estruturas relacionadas a situações de ansiedade e estresse podem ter diferentes níveis de ativação neuronal. De fato, um número considerável de trabalhos tem mostrado que a ansiedade está associada a alterações na atividade da microcircuitaria neuronal em regiões encefálicas especificas (BORELLI, 2006; ALBRECHET, 2010; ALBRECHET-SOUZA; CARVALHO; BRANDAO, 2012; ALMADA; ALBRECHET-SOUZA; BRANDAO, 2013).

Os cérebros dos ratos submetidos ao condicionamento de medo e ao reteste dois meses após, foram analisados com a técnica de imuno-histoquímica para c-FOS para avaliar a ativação de estruturas relacionadas com as respostas defensivas. As áreas do cérebro que marcaram positivamente para o c-FOS corresponderam com resultados publicados em animais não selecionados (BECK; FIBIGER, 1995; LAMPREA et al., 2002). Em algumas regiões o padrão de atividade cerebral evocada foi diferente entre ratos CHF e ratos CLF ou RND, indicando tanto hiper quanto hipoativação de diversas populações neuronais específicas. Das 20 estruturas analisadas encontraram-se diferenças na ativação no PrL, Cg1, no LSD, PVN, no GD, no MS, na BLA, no PR e no LC. Os locais de ativação diferencial entre as linhagens foram particularmente identificados em áreas do sistema límbico, sugerindo que a ativação nestes sistemas e circuitos associados contribui para as diferenças nas respostas comportamentais e fisiológicas entre as linhagens.

O PrL e o Cg1 são sub-regiões do córtex pré-frontal medial (junto com o IL e o Cg2). O córtex pré-frontal medial faz parte do sistema límbico e tem importantes conexões com a amigdala e o hipotálamo que se relacionam com o controle, planejamento e execução de ações regulando funções emocionais e cognitivas associadas à resposta ao estresse (SINGEWALD, 2007). As duas linhagens CHF e CLF apresentaram uma menor ativação do PrL em comparação com o grupo RND, porém os CHF apresentaram uma maior ativação que os CLF. Este é um resultado inesperado, pois vários estudos têm reportado uma relação entre a baixa ativação do PrL e o aumento de comportamentos defensivos (KALISCH et al., 2004; SINGEWALD, 2007). Porém, isso pode ser explicado pelo fato de que a atividade do PrL é 
necessária para recuperar as informações anteriormente aprendidas que ajustam o nível da resposta de ansiedade (STERN et al., 2010). Assim, a ativação do PrL é essencial para a expressão da resposta ansiosa previamente associada com o contexto. Como os ratos utilizados aqui se diferenciam pela resposta de congelamento associado ao contexto é possível que sejam essas as diferencias de ativação no PrL as que estejam modulando essa diferencia na expressão da resposta. Stern et al (2010) bloquearam a ativação do PrL com cobalto e observaram uma redução na expressão de ansiedade no LCE mostrando a importância do PrL na evocação de memorias aversivas.

A diminuição na ativação do córtex cingulado em ratos que apresentavam um fenótipo mais ansioso (ratos $\mathrm{HAB}$ ) em comparação com os de baixa ansiedade (LAB) quando submetidos ao braço aberto, campo aberto e ao modelo de derrota social já tinha sido reportada (KALISCH et al., 2004).

O septum lateral dorsal, o septum medial e o núcleo septohipocampal fazem parte da área septal. Esta área está composta principalmente por fibras de passagem com aferências e eferências dos núcleos septais para estruturas corticais. O núcleo lateral e o núcleo septohipocampal fazem parte da porção lateral da área septal. Existem evidências que indicam que esses núcleos modulam a atividade do eixo HPA salientando a importância nas respostas associadas ao estresse. Os ratos CHF apresentaram uma maior ativação no septum lateral dorsal comparado com o grupo CLF e RND. No caso dos ratos CLF a menor ativação desses núcleos e a menor resposta de congelamento poderiam ser explicadas pelo modelo proposto por Gray e McNaughton (1983) segundo o qual a atividade do complexo septal reflete um estado de "ansiedade", produzido quando há uma incompatibilidade entre os eventos sensoriais previstos e reais. Assim, ao impedir que os animais detectem uma mudança, as lesões ou a inativação do septo causaria uma diminuição do medo ou ansiedade. Nossos resultados também corroboram estudos de lesão do núcleo septal lateral, nos quais observouse uma redução da ansiedade no LCE e no teste de enterramento defensivo em reação à sonda de choque (MENARD; TREIT, 1996). Entretanto foi observada uma redução da ativação no núcleo septal medial nos ratos da linhagem CHF. No mesmo sentido, Bannerman et al (2004) mostraram que lesões no núcleo septal medial não tiveram um efeito no medo condicionado contextual.

Calandreau et al (2007) reportaram que a inativação do MS na verdade resulta na interrupção do condicionamento ao medo contextual no momento do treino, mostrando assim o papel crítico desse núcleo no processamento dos estímulos sinalizadores. A baixa ativação nos ratos CHF se relaciona à baixa discriminação de estímulos sinalizadores que fazem com 
que eles generalizem os estímulos potencialmente aversivos e respondam defensivamente a outros contextos. Dados similares têm sido achados em estudos paralelos do nosso laboratório (Gomes et al, resultados não publicados).

O aumento na expressão de c-FOS nos ratos CHF no PVN era esperado uma vez que, como apresentado no Experimento1, a concentração plasmática de corticosterona nestes animais esta aumentada tanto na linha de base quanto após o estresse. Outros estudos têm mostrado uma relação na ativação do PVN e altas concentrações de corticosterona plasmática (SKORZEWSKA et al., 2007; HSU et al., 2007; DINIZ et al., 2013). Também Lehner et al (2008) mostraram que os ratos selecionados da linhagem HR também apresentaram um aumento da expressão de c-FOS após serem submetidos ao teste do medo condicionado ao contexto.

Hipocampo, amigdala e o córtex peririnal são estruturas telencefálicas importantes no controle e produção das respostas defensivas.

No giro denteado do hipocampo observou-se uma diminuição da atividade neuronal nos ratos da linhagem CHF. Esses resultados corroboram estudos prévios onde os ratos que apresentavam alta ansiedade (HAB) tinham uma baixa ativação no giro denteado após serem submetidos ao braço aberto (SALOME et al., 2004).

Por outro lado, a amigdala basolateral é uma importante estrutura na modulação e consolidação na memória. Os ratos da linhagem CHF apresentaram uma maior ativação que animais dos outros grupos. É interessante observar que os ratos CLF ainda apresentaram menor ativação que os RND e os CHF. Resultados prévios do nosso grupo têm mostrado que lesões eletrolíticas da amígdala causaram uma redução substâncial da quantidade de congelamento condicionado. Curiosamente, este efeito deletério foi semelhante em ambas linhagens $(\sim 60 \%)$, indicando que as altas e baixas taxas de congelamento condicionado não eram selecionadas por uma via neural amígdala-dependente (GOMES; LANDEIRAFERNANDEZ, 2008). Porém esses experimentos foram feitos na $4^{\mathrm{a}}$ geração $\left(\mathrm{S}_{4}\right)$ e não têm sido feitos em gerações mais próximas às gerações utilizadas neste trabalho. Nos nossos resultados, o aumento da atividade na amigdala basolateral nos ratos CHF poderia estar relacionado com o aumento geral da ansiedade e com o aumento da concentração de corticosterona no sangue desses ratos (LEÓN et al., 2013). De fato Sadyik et al reportaram que a injeção de CRF ou urocortina (um peptídeo com uma afinidade semelhante para o receptor de CRF1 mas uma maior afinidade para o receptor CRF2) quando microinjetados na amigdala basolateral, são capazes de produzir comportamento ansiogênico avaliado no teste de interação social(SAJDYK et al., 1999). No mesmo sentido, sabe-se que o bloqueio da 
neurotransmissão inibitória dentro da amígdala basolateral, utilizando bicoculina, pode levar a respostas comportamentais e fisiológicas semelhantes às observadas nos transtornos de ansiedade (SHEKHAR; KATNER, 1995). Também se sabe que durante experiências estressantes levam a um aumento na atividade serotoninérgica no BLA (AMAT et al., 1998).

No córtex perirhinal observou-se uma ativação divergente nas três linhagens. Os ratos CLF apresentaram uma maior atividade que os RND e os CHF. Por outro lado, os CHF apresentaram uma atividade menor que os RND e os CLF, indicando que ratos mais ansiosos têm uma menor atividade nessa estrutura. Esse achado é contrário ao esperado, pois lesões, após o treino, do córtex perirhinal diminuem o tempo de congelamento no teste de medo condicionado a um sinal auditivo ou visual mostrando um efeito ansiolítico da lesão. Porém o resultado pode ser explicado porque se sabe que o córtex perirhinal desempenha um papel importante no processamento visual e, talvez, outras funções cognitivas que podem modular um efeito sobre a memória e não especificamente sobre a ansiedade (CORODIMAS; LEDOUX, 1995). Um estudo realizado por Finkbeiner mostrou que quatro semanas de exercício voluntário a cada dois dias, melhora a memória de reconhecimento de objetos e isso esta associado com um aumento na expressão de BDNF no córtex perirhinal e com a diminuição de comportamento ansioso no LCE. A ligação do BDNF ao seu receptor pode levar a transcrição dependente do ciclo CREB o que por sua vez pode envolver a síntese de mRNA e genes de expressão imediata como c-FOS ou zif268 (FINKBEINER, 2000). Neste sentido, futuros estudos deverão testar o possível aumento de BDNF nesta estrutura nos ratos CLF e CHF.

O locus coeruleus é a estrutura onde se sintetiza norepinefrina (NE). Os ratos da linhagem CHF apresentaram um aumento de expressão da proteína fos em comparação com os CLF nesta região. Sabe-se que a exposição a estressores depleta a NE (WEISS et al., 1980). Vários estudos têm mostrado que a liberação de NE é diminuída quando a depleção é produzida por altas taxas de atividade neuronal, estresse e ou bloqueio de síntese (WEISS et al., 1980; NAKAGAWA et al., 1981). Assim, pode ser que os ratos CHF apresentem uma menor liberação de NE que parece ser protetor aos efeitos de estressores (WEISS; GLAZER, 1975; WEISS et al., 1975). Entretanto, futuros projetos podem avaliar diferenças na síntese e neurotransmissão de NE nestas linhagens.

Nos experimentos 1, 2 e 3 encontramos, respectivamente, (1) uma resposta diferencial do eixo HPA entre as linhagens, (2) diferenças na proliferação celular e (3) diferenças na ativação neuronal em resposta ao estresse. No experimento 4, avaliamos então se animais das linhagens CLF e CHF apresentavam também uma resposta diferencial à manipulação 
serotonérgica no paradigma do labirinto em cruz elevado. O fármaco escolhido foi a ketanserina (que atua como antagonista seletivo dos receptores serotoninérgicos de tipo 5$\mathrm{HT}_{2 \mathrm{~A}}$ ), porque o papel preciso da serotonina na gênese da ansiedade ainda não está bem estabelecido. Existem evidências conflitantes na literatura sobre o papel da serotonina na ansiedade (WISE; BERGER; STEIN, 1972; ZANGROSSI; GRAEFF, 1994; GRAEFF et al., 1996; GRAEFF; ZANGROSSI, Jr., 2010). Pelo menos parte da explicação para estes resultados paradoxais poderiam advir do fato de que sempre os trabalhos experimentais são realizados em populações heterogéneas de animais o que por sua vez levaria a um resultado "médio" dos dados. No presente trabalho observamos que a ketanserina nas duas linhagens de ratos utilizados (CHF e CLF) induziu efeitos diferenciais quando submetidos ao mesmo modelo de ansiedade (LCE). De fato, o efeito farmacológico da ketanserina é diferente para cada traço de ansiedade. Os ratos da linhagem CHF apresentaram um efeito ansiolítico quando injetados sistemicamente e localmente com ketanserina. Os ratos da linhagem CLF apresentaram um efeito tipo ansiogênico quando injetados sistemicamente.

Os receptores 5- $\mathrm{HT}_{2 \mathrm{~A}}$ se expressam principalmente no córtex pré-frontal, gânglios da base, hipocampo, septo, PAG e amígdala (DHONNCHADHA; BOURIN; HASCOET, 2003; BORTOLOZZI et al., 2005; ZANOVELI; NOGUEIRA; ZANGROSSI, Jr., 2005; AMARGOS-BOSCH; ADELL; ARTIGAS, 2007) e têm sido relacionadas às reações de ansiedade (ZANOVELI; NOGUEIRA; ZANGROSSI, Jr., 2005; GRAEFF; ZANGROSSI, Jr., 2010). Por exemplo, Petersen e Scheel-Kruger (1984) mostraram que uma injeção local de ketanserina no complexo amigdalóide aumentou a frequência de consumo de água no teste de supressão pela punição com choque elétrico na língua, mostrando dessa forma um efeito ansiolítico. Na mesma linha de pensamento, Motta et al. encontraram efeitos semelhantes no LCE; uma injeção única de ketanserina $(0,5 \mathrm{mg} / \mathrm{Kg}$; IP) aumentou a quantidade de entradas aos braços abertos, enquanto antagonistas do receptor $5-\mathrm{HT}_{2 \mathrm{C}}$ e $\alpha$-adrenérgicos não tiveram nenhum efeito. Doses mais elevadas $(1 \mathrm{mg} / \mathrm{Kg}$; IP) levaram a mudanças na atividade locomotora (MOTTA et al., 1992).

Petty et al (1994) sugerem que os níveis basais de 5-HT extracelular no neocórtex frontal de animais antes de ser submetidos ao estresse não necessariamente explicam vulnerabilidade neuroquímica do mesmo. No entanto, a alteração dos níveis basais 5-HT extracelular devido ao estresse se correlacionam com o desenvolvimento do desemparo aprendido. Ou seja, os ratos com um maior aumento nos níveis basais de 5-HT causados pelo estresse são mais propensos a tornar-se desamparados do que ratos com menor aumento de 5-HT. Estes dados 
implicam um excesso de 5-HT no espaço extracelular no desenvolvimento de sintomas associados à psicopatologia. Por este fato é possível supor que os ratos das linhagens $\mathrm{CHF}$ e CLF não apresentam diferenças nas concentrações extracelulares de 5-HT antes de ser submetidos à fenotipagem e seja necessário submeter eles ao estresse para perceber as diferenças. Estudos futuros podem testar esta hipótese.

A downregulation de receptores 5- $\mathrm{HT}_{2 \mathrm{~A}}$, após o tratamento crônico com antidepressivos (PEROUTKA; SNYDER, 1980b) e agonistas da serotonina (CONN; SANDERS-BUSH, 1986; SMITH; BARRETT; SANDERS-BUSH, 1999) também tem sido observada em cultura de células e sistemas in vivo (ROTH et al., 1995; SMITH; BARRETT; SANDERS-BUSH, 1999). Acredita-se que a dowregulation no BLA dos receptores 5-HT $2 \mathrm{~A}$ após o estresse inescapável é provavelmente causada pelo aumento crônico de níveis serotonina. Foi observado que o estresse pode aumentar consideravelmente os níveis de serotonina no BLA e este aumento pode durar pelo menos 40 horas após o final do estresse (AMAT et al., 2005). A estimulação prolongada do receptor 5- $\mathrm{HT}_{2 \mathrm{~A}}$ pode, subsequentemente, induzir dessensibilização do receptor e dowregulation. Alternativamente ou adicionalmente, o comprometimento da sinalização do receptor de 5- $\mathrm{HT}_{2 \mathrm{~A}}$ pode resultar de uma interação entre ele e o fator neurotrófico derivado do cérebro (BDNF). Estresse inescapável pode diminuir os níveis de BDNF no cérebro, possivelmente devido aos elevados níveis de glicocorticoides cerebrais (VAIDYA et al., 1997; XU et al., 2006). Também segundo Jiang et al. (2009) o mal funcionamento na modulação serotonérgica da neurotransmissão GABAérgica na amígdala pode ser um mecanismo fundamental subjacente ao aparecimento de sintomas associados com a ansiedade e outros distúrbios associados ao estresse. Os autores mostraram que o $\alpha$-methil5-HT, agonista de receptores 5HT2 e 4, facilita a liberação de GABA e aumenta os potenciais inibitórios pós-sinapticos (PIPS) na BLA e que esse efeito era mediado pelo receptor 5-HT $2 \mathrm{~A}$. Os autores submeteram ratos a estresse de restrição motora e choques na cauda por duas horas durante três dias e observaram que o estresse foi capaz de bloquear o aumento de PIPS. Na avalição do ARNm e os níveis de proteína dos receptores 5-HT $2 \mathrm{~A}$, após o estresse observaram que a exposição ao estresse provocou uma redução significativa da expressão de mRNA do receptor 5-HT $2 \mathrm{~A}$ no BLA e hipocampo comparado com os ratos de controle (JIANG et al., 2009). De acordo com estas evidências é possível considerarmos que a função serotonérgica em animais CHF, que apresentam também uma maior ativação do BLA, e é possível levantar a hipótese de que existem diferenças na linha de base da função serotonérgica em ambas as 
linhagens, o que levaria animais da linhagem CHF serem mais propensos a exibir comportamento ansioso (traços ansiogênicos) do que animais CLF.

A expressão de receptores $5-\mathrm{HT}_{1 \mathrm{~A}}$ também necessita ser avaliada nessas linhagens, pois tem sido observado que os níveis de expressão desse receptor estão associados com a vulnerabilidade ao estresse e com a resposta a antidepressivos. Camundongos com alta ou baixa expressão do autoreceptor, por exemplo, apresentam diferenças na taxa de disparos nos núcleos da rafe, mas não exibem diferenças na liberação de serotonina no cérebro anterior nem no comportamento em testes de conflitos. Porém, camundongos com alta expressão de 5$\mathrm{HT}_{1 \mathrm{~A}}$ apresentam uma resposta aumentada ao estresse agudo, aumento do desamparo comportamental, não apresentando respostas comportamentais ao fármaco. De fato, a diminuição da expressão dos receptores é suficiente para observar a resposta comportamental (RICHARDSON-JONES et al., 2010).

Os nossos resultados sugerem que, no lugar da ativação diferencial de estruturas em resposta à natureza do estímulo (como sugerido pela teoria da distância-defesa), esta ativação dependeria da conformação genética e fenotípica (associada aos processos epigenéticos), do indivíduo. A conformação genética pode conferir linhas de base diferenciais de serotonina, levando a traços diferentes de ansiedade também. Isso explicaria porque manipulações farmacológicas, objetivando as vias serotonérgicas em ratos de populações heterogêneas, levam a resultados paradoxais. Um dos mecanismos mais prováveis subjacentes a este efeito diferencial pode estar na expressão do receptor. Em conjunto, estes podem ser os fatoreschave para determinar o papel da serotonina na ansiedade. Nosso próximo passo é a medição precisa da expressão diferencial dos receptores 5- $\mathrm{HT}_{2 \mathrm{~A}}$ em ratos das linhagens CHF e CLF.

$\mathrm{O}$ fato dos ratos $\mathrm{CHF}$ terem limiares maiores para induzir eletricamente (na matéria cinzenta periaqueductal dorsal) ataques de pânico apoia a ideia de que a ansiedade antecipatória diminui a probabilidade de um ataque de pânico, sugerindo que, assim como mencionado acima, não são dois sistemas separados agindo em diferentes momentos e locais que induzem ansiedade ou de defesa, mas sim um único sistema variando na sua função basal e conferindo características diferenciais de vulnerabilidade à ansiedade e, assim, diferenças na resposta a drogas serotoninérgicas (GALVAO et al., 2011).

De fato, a maior parte de inibidores seletivos da recaptação da serotonina (ISRSs) é utilizada no tratamento do transtorno de pânico e TAG (VAN APELDOORN et al., 2008; SCHUURMANS, 2010; RONCON et al., 2012), indicando que o aumento da função 
serotonérgica pode induzir efeitos de tipo ansiolítico. A função serotonérgica melhorada induzida por ISRSs conduz a alterações em longo prazo na expressão dos receptores serotonérgicos e na dinâmica de ligação do receptor 5-HT 2 (DEAKIN, 1988; HATANAKA et al., 1996; YAMAUCHI et al., 2006). Sempre que há um aumento da liberação de serotonina, o primeiro efeito será um aumento da ansiedade antecipatória. Nesta ordem de ideias, os ratos CHF, devido ao elevado nível de serotonina basal podem ter receptores de serotonina dessensibilizados - downregulation - do mesmo modo como tem sido demonstrado para os tratamentos crónicos com agonistas 5- $\mathrm{HT}_{2}$ (MIYOSHI et al., 2001; GRAY; COMPTONTOTH; ROTH, 2003), e para ISRSs (YAMAUCHI et al., 2006). Isto poderia explicar por que quando os ratos da linhagem CHF são expostos a um antagonista serotonérgico é observado um efeito de tipo ansiolítico. Entretanto, mais estudos são necessários para corroborar esta hipótese.

Lehner et al (2010) utilizaram um modelo de ratos selecionados de acordo com a sua resposta de congelamento, os ratos chamados "low- and high anxiety" . Eles encontraram uma maior expressão dos receptores $\alpha-2$ na amigdala nos ratos "low anxiety" (comparados com o grupo controle). Esses resultados fortalecem a idéia de que possa existir uma expressão diferencial dos receptores, modulando a resposta comportamental, o que levaria naturalmente às diferenças na resposta aos fármacos.

No caso dos ratos da linhagem CLF, a função serotoninérgica reduzida poderia conduzir a uma sensibilização de receptores (upregulation) da mesma maneira que a depleção da 5-HT tem sido associada à sobre regulação de compensação de receptores 5-HT 2 (RENEMAN et al., 2002). Isto poderia explicar por que a mesma dose da mesma droga levou a um efeito normalizador sobre a ansiedade. É importante mencionar que os efeitos encontrados para ketanserina não parecem ser devidos às alterações na atividade locomotora induzida pela droga, porque não foram encontradas diferenças no valor total da distância percorrida no labirinto.

Finalmente, existem também evidências de que a expressão dos receptores $5 \mathrm{HT}_{2 \mathrm{~A}}$ pode ser mediada pela quantidade de corticosterona (FERNANDES et al., 1997; CYR et al., 2001). Dessa forma, poderia se pensar que a redução proposta da expressão de receptores $5-\mathrm{HT}_{2 \mathrm{~A}}$ nos ratos da linhagem $\mathrm{CHF}$ possa ser uma consequência de uma atividade aumentada do eixo HPA. 
Alguns autores sinalam determinados paradigmas experimentais usados no estudo do possível efeito ansiolítico. A variação nos efeitos, e principalmente os diferentes efeitos dos fármacos serotoninérgicos, pode ser também explicada pela variação dos próprios constructos nos quais os modelos representam o medo e a ansiedade (HANDLEY et al., 1993; MCCREARY et al., 1996).

O modelo do LCE tem sido muito útil em estudos pré-clínicos de ansiolíticos típicos, como os benzodiazepínicos (SHEKHAR, 1993; TRENT; MENARD, 2010). Porém fármacos eficazes no tratamento da ansiedade com melhores efeitos clínicos tem questionado a validade desse modelo ao não corroborar o efeito ansiolítico (GRIEBEL et al., 1995). Também é notório que a maioria dos estudos utiliza ratos Wistar "controle" nos quais não é avaliada a linha de base de ansiedade, que, como demonstrado nos nossos resultados e em alguns outros estudos, modula o efeito da droga (CASTRO et al., 2010; CASTRO et al., 2012).

Há um crescente interesse em estudar as diferenças individuais e "traços de personalidade" em modelos animais de psicopatologia. Cada vez mais está se tornando de crucial importância saber as características de linha de base antes de qualquer intervenção comportamental ou farmacológica, com a finalidade de obter conclusões mais precisas. A principal conclusão a partir dos nossos resultados é que não tem sentido para o tratamento de pessoas com diferentes linhas de base de ansiedade (ativação serotoninérgica e perfil neuroendócrino) utilizar a mesma droga e a mesma dose. Estudos adicionais devem ser realizados para determinar se essas diferenças podem ser explicadas pela expressão diferencial de receptores de serotonina e níveis basais da atividade serotonérgica.

É sabido que alguns laboratórios utilizam estudos de variabilidade comportamental entre ratos, prévio à aplicação de determinados procedimentos, como uma forma de selecionar o pool de características comuns a determinadas condições e dessa forma obter menor variabilidade nos resultados (KOOLHAAS et al., 1999; CASTRO et al., 2010). É possível então que mediante a seleção fenotípica seja possível diminuir ainda mais a variabilidade entre sujeitos representantes de uma mesma população. Entretanto, esta variabilidade é extremada quando se comparada a indivíduos de populações opostas fenotipicamente.

É possível presumir que a hereditariedade desempenha um papel importante na explicação dos comportamentos. Entretanto, não podem ser desconhecidos os efeitos e modulações da experiência individual para o desenvolvimento do comportamento. Por isso a importância de continuar fazendo a fenotipagem. A caraterização da linhagem por si mesma 
não é muito útil. Uma descrição de algo que já existe não é muito útil, mas ajuda-nos a identificar caraterísticas associadas à patologia que podem ajudar a prever e controlar o comportamento futuro. Por exemplo, a noção de ativação diferencial das estruturas permitenos um melhor conhecimento dos diferentes sistemas neuroquímicos envolvidos na produção de respostas defensivas. Assim, a criação de linhagens permite um melhor entendimento das caraterísticas que estão na gênese de diversas psicopatologias. 


\section{Conclusões}

- Como uma conclusão geral dos resultados obtidos nos experimentos aqui reportados é útil mencionar a importância de ter uma linha basal do comportamento dos sujeitos, antes da administração de fármacos ou manipulações experimentais, com o intuito de diminuir a variabilidade dos resultados. Futuros estudos podem clarificar as variáveis genéticas.

- As concentrações basais de corticosterona correlacionam com o congelamento das linhagens, e nos ratos CHF e CLF se mantem estáveis. Assim, os ratos da linhagem CHF apresentam uma alta concentração de corticosterona basal (e após o estresse), sendo que os ratos da linhagem CLF apresentam uma concentração baixa antes e após o estresse.

- $\quad$ Os animais da linhagem CHF apresentam uma menor proliferação celular que os ratos CLF e os RND (KI67, BrdU).

- Houve uma diminuição de neurônios imaturos nos ratos CHF que foram submetidos ao protocolo de estresse (DCX).

- Das 20 estruturas analisadas encontraram-se diferenças na ativação (c-FOS) no córtex pré-límbico, no cingulado 1, no septum lateral dorsal, no núcleo paraventricular do hipotálamo, no giro denteado, no septum medial, na amigdala basolateral, no córtex perirhinal e no locus coeruleus. Podem se observar então diferenças nas estruturas associadas com as vias associadas à ansiedade e não aquelas ativadas no pânico.

- O efeito farmacológico da ketanserina é diferecial para cada traço de ansiedade. Os ratos da linhagem CHF apresentaram um efeito ansiolítico quando injetados sistemicamente e localmente com ketanserina. Por outro lado, ratos da linhagem CLF apresentaram um efeito tipo ansiogênico quando injetados sistemicamente. 


\section{Anexo I}

Artigo publicado ao longo do estudo, com tema diretamente relacionado ao trabalho apresentado http://revistas.urosario.edu.co/index.php/apl/article/view/2441/2099 


\section{Referências}

ADAMS, F.; GRASSIE, M.; SHAHID, M.; HILL, D. R. e HENRY, B. Acute oral dexamethasone administration reduces levels of orphan GPCR glucocorticoid-induced receptor (GIR) mRNA in rodent brain: potential role in HPA-axis function. Brain Res.Mol.Brain Res. v. 117, n. 1, p. 39-46, Sep 10 2003. Disponível em: PM:14499479.

AGUILAR-VALLES, A.; SANCHEZ, E.; DE GORTARI, P.; BALDERAS, I.; RAMIREZAMAYA, V.; BERMUDEZ-RATTONI, F. e JOSEPH-BRA VO, P. Analysis of the stress response in rats trained in the water-maze: differential expression of corticotropin-releasing hormone, CRH-R1, glucocorticoid receptors and brain-derived neurotrophic factor in limbic regions. Neuroendocrinology v. 82, n. 5-6, p. 306-319, 2005. Disponível em: PM:16721035.

AISA, B.; TORDERA, R.; LASHERAS, B.; DEL RIO, J. e RAMIREZ, M. J. Cognitive impairment associated to HPA axis hyperactivity after maternal separation in rats.

Psychoneuroendocrinology v. 32, n. 3, p. 256-266, Apr 2007. Disponível em:

PM:17307298.

AISA, B.; TORDERA, R.; LASHERAS, B.; DEL RIO, J. e RAMIREZ, M. J. Effects of maternal separation on hypothalamic-pituitary-adrenal responses, cognition and vulnerability to stress in adult female rats. Neuroscience v. 154, n. 4, p. 1218-1226, Jul 172008.

Disponível em: PM:18554808.

ALBRECHET, L. Fatores hormonais, cognitivos e neuroanatômicos associados ao comportamento exploratório de ratos submetidos ao teste e reteste no labirinto em cruz elevado. 2010. (Doutor). Universidade de São Paulo.

ALBRECHET-SOUZA, L.; CARVALHO, M. C. e BRANDAO, M. L. D1-like receptors in the nucleus accumbens shell regulate the expression of contextual fear conditioning and activity of the anterior cingulate cortex in rats. Int.J.Neuropsychopharmacol., p. 1-13, Sep 11 2012. Disponível em: PM:22964037.

ALFAREZ, D. N.; JOELS, M. e KRUGERS, H. J. Chronic unpredictable stress impairs longterm potentiation in rat hippocampal CA1 area and dentate gyrus in vitro. Eur.J.Neurosci v. 17, n. 9, p. 1928-1934, May 2003. Disponível em: PM:12752792.

ALMADA, R. C.; ALBRECHET-SOUZA, L. e BRANDAO, M. L. Further evidence for involvement of the dorsal hippocampus serotonergic and gamma-aminobutyric acid (GABA)ergic pathways in the expression of contextual fear conditioning in rats. J.Psychopharmacol. Mar 27 2013. Disponível em: PM:23535348.

AMARGOS-BOSCH, M.; ADELL, A. e ARTIGAS, F. Antipsychotic drugs reverse the AMPA receptor-stimulated release of 5-HT in the medial prefrontal cortex. J.Neurochem. $v$. 102, n. 2, p. 550-561, Jul 2007. Disponível em: PM:17394545. 
AMAT, J.; BARATTA, M. V.; PAUL, E.; BLAND, S. T.; WATKINS, L. R. e MAIER, S. F. Medial prefrontal cortex determines how stressor controllability affects behavior and dorsal raphe nucleus. Nat.Neurosci v. 8, n. 3, p. 365-371, Mar 2005. Disponível em: PM:15696163.

AMAT, J.; MATUS-AMAT, P.; WATKINS, L. R. e MAIER, S. F. Escapable and inescapable stress differentially alter extracellular levels of 5-HT in the basolateral amygdala of the rat. Brain Res. v. 812, n. 1-2, p. 113-120, Nov 23 1998. Disponível em: PM:9813270.

AMERICAN PSYCHIATRIC ASSOCIATION. Diagnostic and Statistical Manual of Mental Disorders. 5th. Washington, DC, 2013.

ANDREWS, N. e FILE, S. E. Handling history of rats modifies behavioural effects of drugs in the elevated plus-maze test of anxiety. Eur.J.Pharmacol. v. 235, n. 1, p. 109-112, Apr 22 1993. Disponível em: PM:8519271.

APPEL, N. M.; MITCHELL, W. M.; GARLICK, R. K.; GLENNON, R. A.; TEITLER, M. e DE SOUZA, E. B. Autoradiographic characterization of (+-)-1-(2,5-dimethoxy-4-[125I] iodophenyl)-2-aminopropane ([125I]DOI) binding to 5-HT2 and 5-HT1c receptors in rat brain. J.Pharmacol.Exp.Ther. v. 255, n. 2, p. 843-857, Nov 1990. Disponível em: PM:2243353.

ARCHER, J. Tests for emotionality in rats and mice: a review. Anim Behav. v. 21, n. 2, p. 205-235, May 1973. Disponível em: PM:4578750.

ARISI, G. M. e GARCIA-CAIRASCO, N. Doublecortin-positive newly born granule cells of hippocampus have abnormal apical dendritic morphology in the pilocarpine model of temporal lobe epilepsy. Brain Res. v. 1165, p. 126-134, Aug 24 2007. Disponível em: PM:17662262.

ASSOCIAÇÃO AMERICANA DE PSIQUIATRIA. DSM-IV-TR - Manual diagnóstico e estatístico de transtornos mentais. 4ta ed. Portoalegre: Artmed, 2002.

AZTIRIA, E.; CAPODIECI, G.; ARANCIO, L. e LEANZA, G. Extensive training in a maze task reduces neurogenesis in the adult rat dentate gyrus probably as a result of stress. Neurosci Lett. v. 416, n. 2, p. 133-137, Apr 12 2007. Disponível em: PM:17317003.

BADIA-ELDER, N. E.; STEWART, R. B.; POWROZEK, T. A.; MURPHY, J. M. e LI, T. K. Effects of neuropeptide $\mathrm{Y}$ on sucrose and ethanol intake and on anxiety-like behavior in high alcohol drinking (HAD) and low alcohol drinking (LAD) rats. Alcohol Clin.Exp.Res. v. 27, n. 6, p. 894-899, Jun 2003. Disponível em: PM:12824809.

BAIN, M. J.; DWYER, S. M. e RUSAK, B. Restraint stress affects hippocampal cell proliferation differently in rats and mice. Neurosci Lett. v. 368, n. 1, p. 7-10, Sep 162004. Disponível em: PM:15342123. 
BALU, D. T. e LUCKI, I. Adult hippocampal neurogenesis: Regulation, functional implications, and contribution to disease pathology. Neurosci Biobehav Rev Aug 192008. Disponível em: PM:18786562.

BANASR, M.; VALENTINE, G. W.; LI, X. Y.; GOURLEY, S. L.; TAYLOR, J. R. e DUMAN, R. S. Chronic unpredictable stress decreases cell proliferation in the cerebral cortex of the adult rat. Biol.Psychiatry v. 62, n. 5, p. 496-504, Sep 1 2007. Disponível em: PM:17585885.

BANNERMAN, D. M.; MATTHEWS, P.; DEACON, R. M. e RAWLINS, J. N. Medial septal lesions mimic effects of both selective dorsal and ventral hippocampal lesions.

Behav.Neurosci. v. 118, n. 5, p. 1033-1041, Oct 2004. Disponível em: PM:15506885.

BECK, C. H. e FIBIGER, H. C. Conditioned fear-induced changes in behavior and in the expression of the immediate early gene c-fos: with and without diazepam pretreatment. J.Neurosci. v. 15, n. 1 Pt 2, p. 709-720, Jan 1995. Disponível em: PM:7823174.

BECKER, C.; HAMON, M. e BENOLIEL, J. J. Prevention by 5-HT1A receptor agonists of restraint stress- and yohimbine-induced release of cholecystokinin in the frontal cortex of the freely moving rat. Neuropharmacology v. 38, n. 4, p. 525-532, Apr 1999. Disponível em: PM:10221756.

BENNINGHOVEN, D.; KADUK, A.; WIEGAND, U.; SPECHT, T.; KUNZENDORF, S. e JANTSCHEK, G. Influence of anxiety on the course of heart disease after acute myocardial infarction - risk factor or protective function? Psychother.Psychosom. v. 75, n. 1, p. 56-61, 2006. Disponível em: PM:16361875.

BERENDSEN, H. H. e BROEKKAMP, C. L. Attenuation of 5-HT1A and 5-HT2 but not 5HT1C receptor mediated behaviour in rats following chronic treatment with 5-HT receptor agonists, antagonists or anti-depressants. Psychopharmacology (Berl) v. 105, n. 2, p. 219224, 1991. Disponível em: PM:1839064.

BERSON, S. A. e YALOW, R. S. General principles of radioimmunoassay. Clin.Chim.Acta v. 22, n. 1, p. 51-69, Sep 1968. Disponível em: PM:4882992.

BHATIA, V. e TANDON, R. K. Stress and the gastrointestinal tract.

J.Gastroenterol.Hepatol. v. 20, n. 3, p. 332-339, Mar 2005. Disponível em: PM:15740474.

BLANCHARD, R. J.; FLANNELLY, K. J. e BLANCHARD, D. C. Defensive behavior of laboratory and wild Rattus norvegicus. J.Comp Psychol. v. 100, n. 2, p. 101-107, Jun 1986. Disponível em: PM:3720282.

BORELLI, K. G. Distribuição da proteína Fos no encéfalo durante estados aversivos induzidos pela inibição GABAérgica na substância cinzenta periaquedutal dorsolateral e no colículo inferior. 2006. (Doutor). Universidade de São Paulo. 
BORTOLOZZI, A.; DIAZ-MATAIX, L.; SCORZA, M. C.; CELADA, P. e ARTIGAS, F. The activation of 5-HT receptors in prefrontal cortex enhances dopaminergic activity. J.Neurochem. v. 95, n. 6, p. 1597-1607, Dec 2005. Disponível em: PM:16277612.

BRANDÃO, M. L. As bases biologicas do comportamento: Introdução a Neurociencia. Sao Paulo: Editora Pedagógica e Universitaria, 2004.

BRANDÃO, M. L.; ZANOVELI, J. M.; RUIZ-MARTINEZ, R. C.; OLIVEIRA, L. C. e LANDEIRA-FERNANDEZ, J. Different patterns of freezing behavior organized in the periaqueductal gray of rats: association with different types of anxiety. Behav.Brain Res. v. 188, n. 1, p. 1-13, Mar 17 2008. Disponível em: PM:18054397.

BREMNER, J. D. Stress and brain atrophy. CNS.Neurol.Disord.Drug Targets. v. 5, n. 5, p. 503-512, Oct 2006. Disponível em: PM:17073653.

BREMNER, J. D.; VYTHILINGAM, M.; VERMETTEN, E.; AFZAL, N.; NAZEER, A.; NEWCOMER, J. W. e CHARNEY, D. S. Effects of dexamethasone on declarative memory function in posttraumatic stress disorder. Psychiatry Res. v. 129, n. 1, p. 1-10, Nov 302004. Disponível em: PM:15572179.

BRINKS, V.; DE KLOET, E. R. e OITZL, M. S. Strain specific fear behaviour and glucocorticoid response to aversive events: modelling PTSD in mice. Prog.Brain Res. v. 167, p. 257-261, 2008. Disponível em: PM:18037021.

BROEKKAMP, C. L.; BERENDSEN, H. H.; JENCK, F. e VAN DELFT, A. M. Animal models for anxiety and response to serotonergic drugs. Psychopathology v. 22 Suppl 1, p. 212, 1989. Disponível em: PM:2567038.

BROWN, J.; COOPER-KUHN, C. M.; KEMPERMANN, G.; VAN, P. H.; WINKLER, J.; GAGE, F. H. e KUHN, H. G. Enriched environment and physical activity stimulate hippocampal but not olfactory bulb neurogenesis. Eur.J.Neurosci. v. 17, n. 10, p. 2042-2046, May 2003. Disponível em: PM:12786970.

BRYANT, H. U.; NELSON, D. L.; BUTTON, D.; COLE, H. W.; BAEZ, M. B.; LUCAITES, V. L.; WAINSCOTT, D. B.; WHITESITT, C.; REEL, J.; SIMON, R. e KOPPEL, G. A. A novel class of 5-HT2A receptor antagonists: aryl aminoguanidines. Life Sci. v. 59, n. 15, p. 1259-1268, 1996. Disponível em: PM:8845011.

BUCHANAN, T. W.; KERN, S.; ALLEN, J. S.; TRANEL, D. e KIRSCHBAUM, C. Circadian regulation of cortisol after hippocampal damage in humans. Biol.Psychiatry v. 56, n. 9, p. 651-656, Nov 1 2004. Disponível em: PM:15522248.

BURGHARDT, N. S.; BUSH, D. E.; MCEWEN, B. S. e LEDOUX, J. E. Acute selective serotonin reuptake inhibitors increase conditioned fear expression: blockade with a 5-HT(2C) receptor antagonist. Biol.Psychiatry v. 62, n. 10, p. 1111-1118, Nov 15 2007. Disponível em: PM:17524369. 
CALANDREAU, L.; JAFFARD, R. e DESMEDT, A. Dissociated roles for the lateral and medial septum in elemental and contextual fear conditioning. Learn.Mem. v. 14, n. 6, p. 422429, Jun 2007. Disponível em: PM:17554087.

CARRASCO, J.; MARQUEZ, C.; NADAL, R.; TOBENA, A.; FERNANDEZ-TERUEL, A. e ARMARIO, A. Characterization of central and peripheral components of the hypothalamuspituitary-adrenal axis in the inbred Roman rat strains. Psychoneuroendocrinology v. 33, n. 4, p. 437-445, May 2008. Disponível em: PM:18276081.

CARRION, V. G.; WEEMS, C. F. e REISS, A. L. Stress predicts brain changes in children: a pilot longitudinal study on youth stress, posttraumatic stress disorder, and the hippocampus.

Pediatrics v. 119, n. 3, p. 509-516, Mar 2007. Disponível em: PM:17332204.

CASTRO, J. E.; DIESSLER, S.; VAREA, E.; MARQUEZ, C.; LARSEN, M. H.; CORDERO, M. I. e SANDI, C. Personality traits in rats predict vulnerability and resilience to developing stress-induced depression-like behaviors, HPA axis hyper-reactivity and brain changes in pERK1/2 activity. Psychoneuroendocrinology v. 37, n. 8, p. 1209-1223, Aug 2012. Disponível em: PM:22240307.

CASTRO, J. E.; VAREA, E.; MARQUEZ, C.; CORDERO, M. I.; POIRIER, G. e SANDI, C. Role of the amygdala in antidepressant effects on hippocampal cell proliferation and survival and on depression-like behavior in the rat. PLoS.ONE. v. 5, n. 1, p. e8618, 2010. Disponível em: PM:20062812.

CHAMPAGNE, D. L.; BAGOT, R. C.; VAN HASSELT, F.; RAMAKERS, G.; MEANEY, M. J.; DE KLOET, E. R.; JOELS, M. e KRUGERS, H. Maternal care and hippocampal plasticity: evidence for experience-dependent structural plasticity, altered synaptic functioning, and differential responsiveness to glucocorticoids and stress. J.Neurosci v. 28, n. 23, p. 6037-6045, Jun 4 2008. Disponível em: PM:18524909.

CHARNEY, D. S. Psychobiological mechanisms of resilience and vulnerability: implications for successful adaptation to extreme stress. Am.J.Psychiatry v. 161, n. 2, p. 195-216, Feb 2004. Disponível em: PM:14754765.

CHOPIN, P. e BRILEY, M. Animal models of anxiety: the effect of compounds that modify 5-HT neurotransmission. Trends in Pharmacological Sciences v. 8, n. 10, p. 383-388, Oct 1987. Disponível em: http://www.sciencedirect.com/science/article/B6T1K-47725RG$\underline{1 \mathrm{~J} / 2 / 5 \mathrm{ec} 4 \mathrm{cdd} 937844 \mathrm{~d} 840770345 \mathrm{ce} 0 \mathrm{af} 92 \mathrm{c} 4 .}$

CHOY, K. H.; DE VISSER, Y.; NICHOLS, N. R. e VAN DEN, B. M. Combined neonatal stress and young-adult glucocorticoid stimulation in rats reduce BDNF expression in hippocampus: effects on learning and memory. Hippocampus v. 18, n. 7, p. 655-667, 2008. Disponível em: PM:18398848.

CLOSE, D. A.; YUN, S. S.; MCCORMICK, S. D.; WILDBILL, A. J. e LI, W. 11deoxycortisol is a corticosteroid hormone in the lamprey. Proc.Natl.Acad.Sci.U.S.A v. 107, n. 31, p. 13942-13947, Aug 3 2010. Disponível em: PM:20643930. 
COE, C. L.; KRAMER, M.; CZEH, B.; GOULD, E.; REEVES, A. J.; KIRSCHBAUM, C. e FUCHS, E. Prenatal stress diminishes neurogenesis in the dentate gyrus of juvenile rhesus monkeys. Biol.Psychiatry v. 54, n. 10, p. 1025-1034, Nov 15 2003. Disponível em:

PM:14625144.

CONN, P. J. e SANDERS-BUSH, E. Regulation of serotonin-stimulated phosphoinositide hydrolysis: relation to the serotonin 5-HT-2 binding site. J.Neurosci. v. 6, n. 12, p. 36693675, Dec 1986. Disponível em: PM:3025382.

CORODIMAS, K. P. e LEDOUX, J. E. Disruptive effects of posttraining perirhinal cortex lesions on conditioned fear: contributions of contextual cues. Behav.Neurosci. v. 109, n. 4, p. 613-619, Aug 1995. Disponível em: PM:7576205.

CRITCHLEY, M. A. e HANDLEY, S. L. Effects in the X-maze anxiety model of agents acting at 5-HT1 and 5-HT2 receptors. Psychopharmacology (Berl) v. 93, n. 4, p. 502-506, 1987. Disponível em: PM:3124184.

CYR, M.; CHARBONNEAU, C.; MORISSETTE, M.; ROCHFORD, J.; BARDEN, N. e DI, P. T. Central 5-hydroxytryptamine-2A receptor expression in transgenic mice bearing a glucocorticoid receptor antisense. Neuroendocrinology v. 73, n. 1, p. 37-45, Jan 2001. Disponível em: PM:11174015.

DARNAUDERY, M. e MACCARI, S. Epigenetic programming of the stress response in male and female rats by prenatal restraint stress. Brain Res.Rev v. 57, n. 2, p. 571-585, Mar 2008. Disponível em: PM:18164765.

DARWIN, C. expressão das emoções nos homens e animais. 4ta. São Paulo: Editora Schwarcz, 1872. Acesso em: 2004.

DARWIN, C. El Origen de las especies. 4ta.: Planeta, 1992. ISBN 9781475913712.

DE JONG, I. E. e DE KLOET, E. R. Glucocorticoids and vulnerability to psychostimulant drugs: toward substrate and mechanism. Ann.N.Y.Acad.Sci. v. 1018, p. 192-198, Jun 2004. Disponível em: PM:15240368.

DE KLOET, E. R.; KARST, H. e JOELS, M. Corticosteroid hormones in the central stress response: quick-and-slow. Front Neuroendocrinol. v. 29, n. 2, p. 268-272, May 2008. Disponível em: PM:18067954.

DE QUERVAIN, D. J.; HENKE, K.; AERNI, A.; TREYER, V.; MCGAUGH, J. L.; BERTHOLD, T.; NITSCH, R. M.; BUCK, A.; ROOZENDAAL, B. e HOCK, C. Glucocorticoid-induced impairment of declarative memory retrieval is associated with reduced blood flow in the medial temporal lobe. Eur.J.Neurosci. v. 17, n. 6, p. 1296-1302, Mar 2003. Disponível em: PM:12670318.

DEAKIN, J. F. 5HT2 receptors, depression and anxiety. Pharmacol.Biochem.Behav. v. 29, n. 4, p. 819-820, Apr 1988. Disponível em: PM:3413204. 
DEAKIN, J. F. Depression and 5HT. Int.Clin.Psychopharmacol. v. 6 Suppl 3, p. 23-28, Dec 1991. Disponível em: PM:1806632.

DEAKIN, J. F. e GRAEFF, F. G. 5-HT and mechanisms of defence. J.Psychopharmacol. v. 5, n. 4, p. 305-315, Jan 1991. Disponível em: PM:22282829.

DHONNCHADHA, B. A. N.; BOURIN, M. e HASCOET, M. Anxiolytic-like effects of 5HT2 ligands on three mouse models of anxiety. Behav.Brain Res. v. 140, n. 1-2, p. 203-214, Mar 18 2003. Disponível em: PM:12644293.

DHONNCHADHA, B. A. N.; RIPOLL, N.; CLENET, F.; HASCOET, M. e BOURIN, M. Implication of 5-HT2 receptor subtypes in the mechanism of action of antidepressants in the four plates test. Psychopharmacology (Berl) v. 179, n. 2, p. 418-429, May 2005. Disponível em: PM:15821956.

DIAS, G. P.; BEVILAQUA, M. C.; SILVEIRA, A. C.; LANDEIRA-FERNANDEZ, J. e GARDINO, P. F. Behavioral profile and dorsal hippocampal cells in carioca high-conditioned freezing rats. Behav.Brain Res. Jul 5 2009. Disponível em: PM:19583984.

DINIZ, L.; DOS SANTOS, T. B.; BRITTO, L. R.; CESPEDES, I. C.; GARCIA, M. C.; SPADARI-BRATFISCH, R. C.; MEDALHA, C. C.; DE CASTRO, G. M.; MONTESANO, F. T. e VIANA, M. B. Effects of chronic treatment with corticosterone and imipramine on fos immunoreactivity and adult hippocampal neurogenesis. Behav.Brain Res. v. 238, p. 170-177, Feb 1 2013. Disponível em: PM:23098799.

DONAHOE, J. W. e DORSEL, V. P. Neural Network Models of Cognition: Biobehavioral Foundations.: Elsevier Science, 1997. ISBN 9780080537368. Dsponível em: http://books.google.com.br/books?id=J-ZGbHIL4aAC.

DRAGUNOW, M.; PETERSON, M. R. e ROBERTSON, H. A. Presence of c-fos-like immunoreactivity in the adult rat brain. Eur.J.Pharmacol. v. 135, n. 1, p. 113-114, Mar 3 1987. Disponível em: PM:3106073.

DRUGAN, R. C.; SKOLNICK, P.; PAUL, S. M. e CRAWLEY, J. N. A pretest procedure reliably predicts performance in two animal models of inescapable stress.

Pharmacol.Biochem.Behav. v. 33, n. 3, p. 649-654, Jul 1989. Disponível em: PM:2587607.

EGAN, C. T.; HERRICK-DAVIS, K.; MILLER, K.; GLENNON, R. A. e TEITLER, M. Agonist activity of LSD and lisuride at cloned 5HT2A and 5HT2C receptors.

Psychopharmacology (Berl) v. 136, n. 4, p. 409-414, Apr 1998. Disponível em: PM:9600588.

FANSELOW, M. S. From contextual fear to a dynamic view of memory systems. Trends Cogn Sci. v. 14, n. 1, p. 7-15, Jan 2010. Disponível em: PM:19939724. 
FEDER, A.; NESTLER, E. J. e CHARNEY, D. S. Psychobiology and molecular genetics of resilience. Nat.Rev.Neurosci. v. 10, n. 6, p. 446-457, Jun 2009. Disponível em: PM:19455174.

FERNANDES, C.; MCKITTRICK, C. R.; FILE, S. E. e MCEWEN, B. S. Decreased 5-HT1A and increased 5-HT2A receptor binding after chronic corticosterone associated with a behavioural indication of depression but not anxiety. Psychoneuroendocrinology v. 22, n. 7 , p. 477-491, Oct 1997. Disponível em: PM:9373882.

FILE, S. E.; KENNY, P. J. e CHEETA, S. The role of the dorsal hippocampal serotonergic and cholinergic systems in the modulation of anxiety. Pharmacol.Biochem.Behav. v. 66, $\mathrm{n}$. 1, p. 65-72, May 2000. Disponível em: PM:10837844.

FINKBEINER, S. Calcium regulation of the brain-derived neurotrophic factor gene. Cell Mol.Life Sci. v. 57, n. 3, p. 394-401, Mar 2000. Disponível em: PM:10823240.

FLUTTERT, M.; DALM, S. e OITZL, M. S. A refined method for sequential blood sampling by tail incision in rats. Lab Anim v. 34, n. 4, p. 372-378, Oct 2000. Disponível em: PM:11072857.

GALVAO, B.; GOMES, V.; MAISONNETTE, S. e LANDEIRA-FERNANDEZ, J. Paniclike behaviors in Carioca High-and Low-conditioned Freezing rats. Psychology \& Neuroscience v. 4, n. 2, p. 205-210, 2011.

GARCIA, A. M.; CARDENAS, F. P. e MORATO, S. Effect of different illumination levels on rat behavior in the elevated plus-maze. Physiol Behav. v. 85, n. 3, p. 265-270, Jun 30 2005. Disponível em: PM:15927214.

GARGIULO, P. A.; VIANA, M. B.; GRAEFF, F. G.; SILVA, M. A. e TOMAZ, C. Effects of anxiety and memory of systemic and intra-amygdala injection of 5-HT3 receptor antagonist BRL 46470A. Neuropsychobiology v. 33, n. 4, p. 189-195, 1996. Disponível em: PM:8840342.

GELLER, I. e BLUM, K. The effects of 5-HTP on para-chlorophenylalanine (p-CPA) attenuation of $\Gamma C ̧ £ c o n f l i c t \Gamma C ̧ \varnothing$ behavior. European Journal of Pharmacology v. 9, n. 3, p. 319-324, Mar 1970. Disponível em: http://www.sciencedirect.com/science/article/pii/0014299970902293.

GENTSCH, C.; LICHTSTEINER, M. e FEER, H. Locomotor activity, defecation score and corticosterone levels during an openfield exposure: a comparison among individually and group-housed rats, and genetically selected rat lines. Physiol Behav. v. 27, n. 1, p. 183-186, Jul 1981. Disponível em: PM:7196593.

GODSIL, B. P.; QUINN, J. J. e FANSELOW, M. S. Body temperature as a conditional response measure for pavlovian fear conditioning. Learn.Mem. v. 7, n. 5, p. 353-356, Sep 2000. Disponível em: PM:11040267. 
GOMES, F. V.; REIS, D. G.; ALVES, F. H.; CORREA, F. M.; GUIMARAES, F. S. e RESSTEL, L. B. Cannabidiol injected into the bed nucleus of the stria terminalis reduces the expression of contextual fear conditioning via 5-HT1 A receptors. J.Psychopharmacol. v. 26, n. 1, p. 104-113, Jan 2012. Disponível em: PM:21148020.

GOMES, V. e LANDEIRA-FERNANDEZ, J. Amygdaloid lesions produced similar contextual fear conditioning disruption in the Carioca high- and low-conditioned freezing rats. Brain Res. v. 1233, p. 137-145, Oct 3 2008. Disponível em: PM:18691560.

GOULD, E.; MCEWEN, B. S.; TANAPAT, P.; GALEA, L. A. e FUCHS, E. Neurogenesis in the dentate gyrus of the adult tree shrew is regulated by psychosocial stress and NMDA receptor activation. J.Neurosci. v. 17, n. 7, p. 2492-2498, Apr 1 1997. Disponível em: PM:9065509.

GOULD, E.; REEVES, A. J.; FALLAH, M.; TANAPAT, P.; GROSS, C. G. e FUCHS, E. Hippocampal neurogenesis in adult Old World primates. Proc.Natl.Acad.Sci.U.S.A v. 96, n. 9, p. 5263-5267, Apr 27 1999a. Disponível em: PM:10220454.

GOULD, E.; TANAPAT, P.; HASTINGS, N. B. e SHORS, T. J. Neurogenesis in adulthood: a possible role in learning. Trends Cogn Sci. v. 3, n. 5, p. 186-192, May 1999b. Disponível em: PM:10322475.

GRAEFF, F. G. Minor tranquilizers and brain defense systems. Braz.J.Med.Biol.Res. v. 14, n. 4-5, p. 239-265, Oct 1981. Disponível em: PM:6124290.

GRAEFF, F. G. Neuroanatomy and neurotransmitter regulation of defensive behaviors and related emotions in mammals. Braz.J.Med.Biol.Res. v. 27, n. 4, p. 811-829, Apr 1994. Disponível em: PM:7916235.

GRAEFF, F. G.; GUIMARAES, F. S.; DE ANDRADE, T. G. e DEAKIN, J. F. Role of 5-HT in stress, anxiety, and depression. Pharmacol.Biochem.Behav. v. 54, n. 1, p. 129-141, May 1996. Disponível em: PM:8728550.

GRAEFF, F. G.; VIANA, M. B. e MORA, P. O. Dual role of 5-HT in defense and anxiety. Neurosci.Biobehav.Rev. v. 21, n. 6, p. 791-799, Nov 1997. Disponível em: PM:9415904.

GRAEFF, F. G. e ZANGROSSI, H., JR. The dual role of serotonin in defense and the mode of action of antidepressants on generalized anxiety and panic disorders.

Cent.Nerv.Syst.Agents Med.Chem. v. 10, n. 3, p. 207-217, Sep 1 2010. Disponível em: PM:20528764.

GRATZNER, H. G.; ETTINGER, N.; INGRAM, D. e CASTRO, A. Immunochemical studies of 5-bromodeoxyuridine. Res.Commun.Chem.Pathol.Pharmacol. v. 20, n. 3, p. 539-548, Jun 1978. Disponível em: PM:566947. 
GRAY, J. A.; COMPTON-TOTH, B. A. e ROTH, B. L. Identification of two serine residues essential for agonist-induced 5-HT2A receptor desensitization. Biochemistry v. 42, n. 36, p. 10853-10862, Sep 16 2003. Disponível em: PM:12962510.

GRAY, J. A. e MCNAUGHTON, N. The neuropsychology of anxiety: an enquiry into the functions of the septo-hippocampal system. 2nd. USA: Oxford University Press, 2000.

GRAY, J. A. e MCNAUGHTON, N. Comparison between the behavioural effects of septal and hippocampal lesions: a review. Neurosci.Biobehav.Rev. v. 7, n. 2, p. 119-188, 1983. Disponível em: PM:6348604.

GRIEBEL, G. 5-Hydroxytryptamine-interacting drugs in animal models of anxiety disorders: more than 30 years of research. Pharmacol.Ther. v. 65, n. 3, p. 319-395, Mar 1995. Disponível em: PM:7644567.

GRIEBEL, G.; BLANCHARD, D. C.; JUNG, A.; MASUDA, C. K. e BLANCHARD, R. J. 5HT1A agonists modulate mouse antipredator defensive behavior differently from the 5-HT2A antagonist pirenperone. Pharmacol.Biochem.Behav. v. 51, n. 2-3, p. 235-244, Jun 1995. Disponível em: PM:7667334.

GROENEWEG, F. L.; KARST, H.; DE KLOET, E. R. e JOELS, M. Mineralocorticoid and glucocorticoid receptors at the neuronal membrane, regulators of nongenomic corticosteroid signalling. Mol.Cell Endocrinol. v. 350, n. 2, p. 299-309, Mar 24 2012. Disponível em: PM:21736918.

GROSS, C. e HEN, R. Genetic and environmental factors interact to influence anxiety. Neurotox.Res. v. 6, n. 6, p. 493-501, 2004. Disponível em: PM:15639782.

HANDLEY, S. L.; MCBLANE, J. W.; CRITCHLEY, M. A. e NJUNG'E, K. Multiple serotonin mechanisms in animal models of anxiety: environmental, emotional and cognitive factors. Behav.Brain Res. v. 58, n. 1-2, p. 203-210, Dec 20 1993. Disponível em: PM:8136047.

HATANAKA, K.; NOMURA, T.; HIDAKA, K.; TAKEUCHI, H.; YATSUGI, S.; FUJII, M. e YAMAGUCHI, T. Biochemical profile of YM992, a novel selective serotonin reuptake inhibitor with 5-HT2A receptor antagonistic activity. Neuropharmacology v. 35, n. 11, p. 1621-1626, 1996. Disponível em: PM:9025110.

HEIM, C.; NEWPORT, D. J.; MLETZKO, T.; MILLER, A. H. e NEMEROFF, C. B. The link between childhood trauma and depression: insights from HPA axis studies in humans.

Psychoneuroendocrinology v. 33, n. 6, p. 693-710, Jul 2008. Disponível em: PM:18602762.

HERDEGEN, T. e LEAH, J. D. Inducible and constitutive transcription factors in the mammalian nervous system: control of gene expression by Jun, Fos and Krox, and CREB/ATF proteins. Brain Res.Brain Res.Rev. v. 28, n. 3, p. 370-490, Dec 1998. Disponível em: PM:9858769. 
HOYER, D.; CLARKE, D. E.; FOZARD, J. R.; HARTIG, P. R.; MARTIN, G. R.; MYLECHARANE, E. J.; SAXENA, P. R. e HUMPHREY, P. P. International Union of Pharmacology classification of receptors for 5-hydroxytryptamine (Serotonin).

Pharmacol.Rev. v. 46, n. 2, p. 157-203, Jun 1994. Disponível em: PM:7938165.

HSU, H. R.; CHEN, T. Y.; CHAN, M. H. e CHEN, H. H. Acute effects of nicotine on restraint stress-induced anxiety-like behavior, c-Fos expression, and corticosterone release in mice. Eur.J.Pharmacol. v. 566, n. 1-3, p. 124-131, Jul 2 2007. Disponível em:

PM:17459372.

HUMPHREY, P. P.; HARTIG, P. e HOYER, D. A proposed new nomenclature for 5-HT receptors. Trends Pharmacol.Sci. v. 14, n. 6, p. 233-236, Jun 1993. Disponível em: PM:8372403.

INDOVINA, I.; ROBBINS, T. W.; NUNEZ-ELIZALDE, A. O.; DUNN, B. D. e BISHOP, S. J. Fear-conditioning mechanisms associated with trait vulnerability to anxiety in humans. Neuron v. 69, n. 3, p. 563-571, Feb 10 2011. Disponível em: PM:21315265.

JACOBS, B. L.; VAN, P. H. e GAGE, F. H. Adult brain neurogenesis and psychiatry: a novel theory of depression. Mol.Psychiatry v. 5, n. 3, p. 262-269, May 2000. Disponível em: PM:10889528.

JANSEN, A. S.; NGUYEN, X. V.; KARPITSKIY, V.; METTENLEITER, T. C. e LOEWY, A. D. Central command neurons of the sympathetic nervous system: basis of the fight-orflight response. Science v. 270, n. 5236, p. 644-646, Oct 27 1995. Disponível em: PM:7570024.

JAYATISSA, M. N.; BISGAARD, C. F.; WEST, M. J. e WIBORG, O. The number of granule cells in rat hippocampus is reduced after chronic mild stress and re-established after chronic escitalopram treatment. Neuropharmacology v. 54, n. 3, p. 530-541, Mar 2008. Disponível em: PM:18164735.

JENCK, F.; BROEKKAMP, C. L. e VAN DELFT, A. M. Effects of serotonin receptor antagonists on PAG stimulation induced aversion: different contributions of 5HT1, 5HT2 and 5HT3 receptors. Psychopharmacology (Berl) v. 97, n. 4, p. 489-495, 1989. Disponível em: PM:2498946.

JIANG, X.; XING, G.; YANG, C.; VERMA, A.; ZHANG, L. e LI, H. Stress impairs 5-HT2A receptor-mediated serotonergic facilitation of GABA release in juvenile rat basolateral amygdala. Neuropsychopharmacology v. 34, n. 2, p. 410-423, Jan 2009. Disponível em: PM:18536707.

JOCA, S. R.; PADOVAN, C. M. e GUIMARAES, F. S. Activation of post-synaptic 5HT(1A) receptors in the dorsal hippocampus prevents learned helplessness development. Brain Res. v. 978, n. 1-2, p. 177-184, Jul 18 2003. Disponível em: PM:12834912. 
KACZMAREK, L.; ZANGENEHPOUR, S. e CHAUDHURI, A. Sensory regulation of immediate-early genes c-fos and zif268 in monkey visual cortex at birth and throughout the critical period. Cereb.Cortex v. 9, n. 2, p. 179-187, Mar 1999. Disponível em: PM:10220230.

KALISCH, R.; SALOME, N.; PLATZER, S.; WIGGER, A.; CZISCH, M.; SOMMER, W.; SINGEWALD, N.; HEILIG, M.; BERTHELE, A.; HOLSBOER, F.; LANDGRAF, R. e AUER, D. P. High trait anxiety and hyporeactivity to stress of the dorsomedial prefrontal cortex: a combined phMRI and Fos study in rats. Neuroimage. v. 23, n. 1, p. 382-391, Sep 2004. Disponível em: PM:15325386.

KARTEN, Y. J.; OLARIU, A. e CAMERON, H. A. Stress in early life inhibits neurogenesis in adulthood. Trends Neurosci v. 28, n. 4, p. 171-172, Apr 2005. Disponível em: PM:15808349.

KEE, N.; SIVALINGAM, S.; BOONSTRA, R. e WOJTOWICZ, J. M. The utility of Ki-67 and BrdU as proliferative markers of adult neurogenesis. J.Neurosci Methods v. 115, n. 1, p. 97-105, Mar 30 2002. Disponível em: PM:11897369.

KEMPERMANN, G.; VAN, P. H. e GAGE, F. H. Activity-dependent regulation of neuronal plasticity and self repair. Prog.Brain Res. v. 127, p. 35-48, 2000. Disponível em: PM:11142036.

KHEIRBEK, M. A.; KLEMENHAGEN, K. C.; SAHAY, A. e HEN, R. Neurogenesis and generalization: a new approach to stratify and treat anxiety disorders. Nat.Neurosci. v. 15, n. 12, p. 1613-1620, Dec 2012. Disponível em: PM:23187693.

KOOB, G. F. e HEINRICHS, S. C. A role for corticotropin releasing factor and urocortin in behavioral responses to stressors. Brain Res. v. 848, n. 1-2, p. 141-152, Nov 271999. Disponível em: PM:10612706.

KOOLHAAS, J. M. Coping style and immunity in animals: making sense of individual variation. Brain Behav.Immun. v. 22, n. 5, p. 662-667, Jul 2008. Disponível em: PM:18395410.

KOOLHAAS, J. M.; BARTOLOMUCCI, A.; BUWALDA, B.; DE BOER, S. F.; FLUGGE, G.; KORTE, S. M.; MEERLO, P.; MURISON, R.; OLIVIER, B.; PALANZA, P.; RICHTERLEVIN, G.; SGOIFO, A.; STEIMER, T.; STIEDL, O.; VAN, D. G.; WOHR, M. e FUCHS, E. Stress revisited: a critical evaluation of the stress concept. Neurosci.Biobehav.Rev. v. 35, n. 5, p. 1291-1301, Apr 2011. Disponível em: PM:21316391.

KOOLHAAS, J. M.; DE BOER, S. F.; COPPENS, C. M. e BUWALDA, B. Neuroendocrinology of coping styles: towards understanding the biology of individual variation. Front Neuroendocrinol. v. 31, n. 3, p. 307-321, Jul 2010. Disponível em: PM:20382177.

KOOLHAAS, J. M.; KORTE, S. M.; DE BOER, S. F.; VAN DER VEGT, B. J.; VAN REENEN, C. G.; HOPSTER, H.; DE JONG, I. C.; RUIS, M. A. e BLOKHUIS, H. J. Coping 
styles in animals: current status in behavior and stress-physiology. Neurosci.Biobehav.Rev. v. 23, n. 7, p. 925-935, Nov 1999. Disponível em: PM:10580307.

KORTE, S. M. Corticosteroids in relation to fear, anxiety and psychopathology.

Neurosci.Biobehav.Rev. v. 25, n. 2, p. 117-142, Mar 2001. Disponível em: PM:11323078.

KUKOLJA, J.; THIEL, C. M.; WOLF, O. T. e FINK, G. R. Increased cortisol levels in cognitively challenging situations are beneficial in young but not older subjects.

Psychopharmacology (Berl) Aug 14 2008. Disponível em: PM:18704371.

LAMPREA, M. R.; CARDENAS, F. P.; VIANNA, D. M.; CASTILHO, V. M.; CRUZMORALES, S. E. e BRANDAO, M. L. The distribution of fos immunoreactivity in rat brain following freezing and escape responses elicited by electrical stimulation of the inferior colliculus. Brain Res. v. 950, n. 1-2, p. 186-194, Sep 20 2002. Disponível em: PM:12231243.

LANDGRAF, R.; KESSLER, M. S.; BUNCK, M.; MURGATROYD, C.; SPENGLER, D.; ZIMBELMANN, M.; NUSSBAUMER, M.; CZIBERE, L.; TURCK, C. W.; SINGEWALD, N.; RUJESCU, D. e FRANK, E. Candidate genes of anxiety-related behavior in HAB/LAB rats and mice: focus on vasopressin and glyoxalase-I. Neurosci.Biobehav.Rev. v. 31, n. 1, p. 89-102, 2007. Disponível em: PM:16934871.

LANDGRAF, R. e WIGGER, A. Born to be anxious: neuroendocrine and genetic correlates of trait anxiety in HAB rats. Stress. v. 6, n. 2, p. 111-119, Jun 2003. Disponível em: PM:12775330.

LAPLAGNE, D. A.; ESPOSITO, M. S.; PIATTI, V. C.; MORGENSTERN, N. A.; ZHAO, C.; VAN, P. H.; GAGE, F. H. e SCHINDER, A. F. Functional convergence of neurons generated in the developing and adult hippocampus. PLoS.Biol. v. 4, n. 12, p. e409, Nov 2006. Disponível em: PM:17121455.

LEE, K. J.; KIM, S. J.; KIM, S. W.; CHOI, S. H.; SHIN, Y. C.; PARK, S. H.; MOON, B. H.; CHO, E.; LEE, M. S.; CHOI, S. H.; CHUN, B. G. e SHIN, K. H. Chronic mild stress decreases survival, but not proliferation, of new-born cells in adult rat hippocampus. Exp.Mol.Med. v. 38, n. 1, p. 44-54, Feb 28 2006. Disponível em: PM:16520552.

LEE, W. E.; WADSWORTH, M. E. e HOTOPF, M. The protective role of trait anxiety: a longitudinal cohort study. Psychol.Med. v. 36, n. 3, p. 345-351, Mar 2006. Disponível em: PM:16393365.

LEHNER, M.; TARACHA, E.; SKORZEWSKA, A.; TURZYNSKA, D.; SOBOLEWSKA, A.; MACIEJAK, P.; SZYNDLER, J.; HAMED, A.; BIDZINSKI, A.; WISLOWSKASTANEK, A. e PLAZNIK, A. Expression of c-Fos and CRF in the brains of rats differing in the strength of a fear response. Behav.Brain Res. v. 188, n. 1, p. 154-167, Mar 172008. Disponível em: PM:18067977.

LEHNER, M.; WISLOWSKA-STANEK, A.; SKORZEWSKA, A.; MACIEJAK, P.; SZYNDLER, J.; TURZYNSKA, D.; SOBOLEWSKA, A. e PLAZNIK, A. Differences in the 
density of GABA-A receptor alpha-2 subunits and gephyrin in brain structures of rats selected for low and high anxiety in basal and fear-stimulated conditions, in a model of contextual fear conditioning. Neurobiol.Learn.Mem. v. 94, n. 4, p. 499-508, Nov 2010. Disponível em: PM:20833253.

LEHNER, M.; WISLOWSKA-STANEK, A.; TARACHA, E.; MACIEJAK, P.; SZYNDLER, J.; SKORZEWSKA, A.; TURZYNSKA, D.; SOBOLEWSKA, A.; HAMED, A.;

BIDZINSKI, A. e PLAZNIK, A. The expression of c-Fos and colocalisation of c-Fos and glucocorticoid receptors in brain structures of low and high anxiety rats subjected to extinction trials and re-learning of a conditioned fear response. Neurobiol.Learn.Mem. v. 92, n. 4, p. 535-543, Nov 2009. Disponível em: PM:19596457.

LEON, L. A. e CARDENAS, F. P. Encefalización y procesos humanos. In GUTIÉRREZ, G. e PAPINI, M. R. (Eds.) Darwin y las ciencias del comportamiento. Ed. Universidad Nacional de Colombia. 2011. p.415-430.

LEÓN, L. A.; GOMES, V. C.; BRANDÃO, M. L.; RODRIGUES, C.; CARDENAS, F. P. e LANDEIRA-FERNANDEZ, J. Corticosterone plasma concentrations in Carioca High- and Low-conditioned freezing rats after a fear conditioned task. Avances en Psicología Latinoamericana v. 31, p. 279-287, 2013.

LEON, L. A.; LANDEIRA-FERNANDEZ, J. e CARDENAS, F. P. Effects of chronic intracerebroventricular 3,4-methylenedioxy-N-methamphetamine (MDMA) or fluoxetine on the active avoidance test in rats with or without exposure to mild chronic stress. Behav.Brain Res. v. 205, n. 1, p. 259-264, Dec 14 2009. Disponível em: PM:19589359.

LEYSEN, J. E.; NIEMEGEERS, C. J.; VAN NUETEN, J. M. e LADURON, P. M. [3H]Ketanserin ( $\mathrm{R} 41468$ ), a selective 3H-ligand for serotonin2 receptor binding sites. Binding properties, brain distribution, and functional role. Mol.Pharmacol. v. 21, n. 2, p. 301-314, Mar 1982. Disponível em: PM:7099138.

LIEBSCH, G.; LINTHORST, A. C.; NEUMANN, I. D.; REUL, J. M.; HOLSBOER, F. e LANDGRAF, R. Behavioral, physiological, and neuroendocrine stress responses and differential sensitivity to diazepam in two Wistar rat lines selectively bred for high- and lowanxiety-related behavior. Neuropsychopharmacology v. 19, n. 5, p. 381-396, Nov 1998. Disponível em: PM:9778660.

LINDFORS, P. e LUNDBERG, U. Is low cortisol release an indicator of positive health? Stress and Health v. 18, n. 4, p. 153-160, Oct 1 2002. Disponível em: http://dx.doi.org/10.1002/smi.942.

LUCASSEN, P. J.; BOSCH, O. J.; JOUSMA, E.; KROMER, S. A.; ANDREW, R.; SECKL, J. R. e NEUMANN, I. D. Prenatal stress reduces postnatal neurogenesis in rats selectively bred for high, but not low, anxiety: possible key role of placental 11 beta-hydroxysteroid dehydrogenase type 2. Eur.J.Neurosci. v. 29, n. 1, p. 97-103, Jan 2009. Disponível em: PM:19032587. 
MALLO, T.; KOIV, K.; KOPPEL, I.; RAUDKIVI, K.; UUSTARE, A.; RINKEN, A.; TIMMUSK, T. e HARRO, J. Regulation of extracellular serotonin levels and brain-derived neurotrophic factor in rats with high and low exploratory activity. Brain Res. v. 1194, p. 110117, Feb 15 2008. Disponível em: PM:18177844.

MAREK, G. J.; CARPENTER, L. L.; MCDOUGLE, C. J. e PRICE, L. H. Synergistic action of 5-HT2A antagonists and selective serotonin reuptake inhibitors in neuropsychiatric disorders. Neuropsychopharmacology v. 28, n. 2, p. 402-412, Feb 2003. Disponível em: PM:12589395.

MARQUEZ, C.; NADAL, R. e ARMARIO, A. The hypothalamic-pituitary-adrenal and glucose responses to daily repeated immobilisation stress in rats: individual differences. Neuroscience v. 123, n. 3, p. 601-612, 2004. Disponível em: PM:14706773.

MCCREARY, A. C.; MCBLANE, J. W.; SPOONER, H. A. e HANDLEY, S. L. 5-HT systems and anxiety: multiple mechanisms in the elevated X-maze. Pol.J.Pharmacol. v. 48, n. 1, p. 1-12, Jan 1996. Disponível em: PM:9112622.

MCDOUGLE, C. J.; EPPERSON, C. N.; PELTON, G. H.; WASYLINK, S. e PRICE, L. H. A double-blind, placebo-controlled study of risperidone addition in serotonin reuptake inhibitorrefractory obsessive-compulsive disorder. Arch.Gen.Psychiatry v. 57, n. 8, p. 794-801, Aug 2000. Disponível em: PM:10920469.

MCNAUGHTON, N. e CORR, P. J. A two-dimensional neuropsychology of defense: fear/anxiety and defensive distance. Neurosci.Biobehav.Rev. v. 28, n. 3, p. 285-305, May 2004. Disponível em: PM:15225972.

MENARD, J. e TREIT, D. Lateral and medial septal lesions reduce anxiety in the plus-maze and probe-burying tests. Physiol Behav. v. 60, n. 3, p. 845-853, Sep 1996. Disponível em: PM:8873261.

MENARD, J. L.; CHAMPAGNE, D. L. e MEANEY, M. J. Variations of maternal care differentially influence 'fear' reactivity and regional patterns of cFos immunoreactivity in response to the shock-probe burying test. Neuroscience v. 129, n. 2, p. 297-308, 2004. Disponível em: PM:15501588.

MIRESCU, C.; PETERS, J. D. e GOULD, E. Early life experience alters response of adult neurogenesis to stress. Nat.Neurosci v. 7, n. 8, p. 841-846, Aug 2004. Disponível em: PM:15273691.

MITRA, R. e SAPOLSKY, R. M. Acute corticosterone treatment is sufficient to induce anxiety and amygdaloid dendritic hypertrophy. Proc.Natl.Acad.Sci.U.S.A v. 105, n. 14, p. 5573-5578, Apr 8 2008. Disponível em: PM:18391224.

MIYOSHI, I.; KAGAYA, A.; KOHCHI, C.; MORINOBU, S. e YAMAWAKI, S. Characterization of 5-HT2A receptor desensitization and the effect of cycloheximide on it in C6 cells. J.Neural Transm. v. 108, n. 3, p. 249-260, 2001. Disponível em: PM:11341476. 
MORGAN, J. I. e CURRAN, T. Proto-oncogene transcription factors and epilepsy. Trends Pharmacol.Sci. v. 12, n. 9, p. 343-349, Sep 1991. Disponível em: PM:1949203.

MOTTA, V.; MAISONNETTE, S.; MORATO, S.; CASTRECHINI, P. e BRANDAO, M. L. Effects of blockade of 5-HT2 receptors and activation of 5-HT1A receptors on the exploratory activity of rats in the elevated plus-maze. Psychopharmacology (Berl) v. 107, n. 1, p. 135139, 1992. Disponível em: PM:1350349.

MUIGG, P.; HOELZL, U.; PALFRADER, K.; NEUMANN, I.; WIGGER, A.; LANDGRAF, R. e SINGEWALD, N. Altered brain activation pattern associated with drug-induced attenuation of enhanced depression-like behavior in rats bred for high anxiety.

Biol.Psychiatry v. 61, n. 6, p. 782-796, Mar 15 2007. Disponível em: PM:17224133.

NAKAGAWA, R.; TANAKA, M.; KOHNO, Y.; NODA, Y. e NAGASAKI, N. Regional responses of rat brain noradrenergic neurones to acute intense stress.

Pharmacol.Biochem.Behav. v. 14, n. 5, p. 729-732, May 1981. Disponível em: PM:7195579.

NEUMANN, I. D.; WIGGER, A.; LIEBSCH, G.; HOLSBOER, F. e LANDGRAF, R. Increased basal activity of the hypothalamo-pituitary-adrenal axis during pregnancy in rats bred for high anxiety-related behaviour. Psychoneuroendocrinology v. 23, n. 5, p. 449-463, Jul 1998. Disponível em: PM:9802120.

OLIJSLAGERS, J. E.; DE KLOET, E. R.; ELGERSMA, Y.; VAN WOERDEN, G. M.; JOELS, M. e KARST, H. Rapid changes in hippocampal CA1 pyramidal cell function via pre- as well as postsynaptic membrane mineralocorticoid receptors. Eur.J.Neurosci v. 27, n. 10, p. 2542-2550, May 2008. Disponível em: PM:18547242.

OLIVEIRA, L. C. Envolvimento de receptores 5-HT2A da substancia cinzenta periaquedutal no medo condicionado e incondicionado de ratos. 2007.

OLIVEIRA, L. C.; BROIZ, A. C.; DE MACEDO, C. E.; LANDEIRA-FERNANDEZ, J. e BRANDAO, M. L. 5-HT2 receptor mechanisms of the dorsal periaqueductal gray in the conditioned and unconditioned fear in rats. Psychopharmacology (Berl) v. 191, n. 2, p. 253262, Apr 2007. Disponível em: PM:17205316.

OOMEN, C. A.; MAYER, J. L.; DE KLOET, E. R.; JOELS, M. e LUCASSEN, P. J. Brief treatment with the glucocorticoid receptor antagonist mifepristone normalizes the reduction in neurogenesis after chronic stress. Eur.J.Neurosci. v. 26, n. 12, p. 3395-3401, Dec 2007. Disponível em: PM:18052970.

OVERSTREET, D. H.; REZVANI, A. H.; PUCILOWSKI, O.; GAUSE, L. e JANOWSKY, D. S. Rapid selection for serotonin-1A sensitivity in rats. Psychiatr.Genet. v. 4, n. 1, p. 5762, 1994. Disponível em: PM:8049904.

PAXINOS, G. e WATSON, C. The rat brain in stereotaxic coordinates. 6ta. Amsterdam: Elsevier, 2007. 
PELLOW, S. Anxiolytic and anxiogenic drug effects in a novel test of anxiety: are exploratory models of anxiety in rodents valid? Methods Find.Exp.Clin.Pharmacol. v. 8, n. 9, p. 557-565, Sep 1986. Disponível em: PM:2877126.

PEROUTKA, S. J. e SNYDER, S. H. Long-term antidepressant treatment decreases spiroperidol-labeled serotonin receptor binding. Science v. 210, n. 4465, p. 88-90, Oct 3 1980a. Disponível em: PM:6251550.

PEROUTKA, S. J. e SNYDER, S. H. Regulation of serotonin2 (5-HT2) receptors labeled with $[3 \mathrm{H}]$ spiroperidol by chronic treatment with the antidepressant amitriptyline.

J.Pharmacol.Exp.Ther. v. 215, n. 3, p. 582-587, Dec 1980b. Disponível em: PM:6255132.

PETERSEN, E. N. e SCHEEL-KRUGER, J. Anticonflict effects of 5-HT antagonists by intraamygdaloid injection. 1984. p.pp. 654.

PETTY, F.; KRAMER, G.; WILSON, L. e JORDAN, S. In vivo serotonin release and learned helplessness. Psychiatry Res. v. 52, n. 3, p. 285-293, Jun 1994. Disponível em: PM:7991722.

PHILLIPS, R. G. e LEDOUX, J. E. Lesions of the dorsal hippocampal formation interfere with background but not foreground contextual fear conditioning. Learn.Mem. v. 1, n. 1, p. 34-44, May 1994. Disponível em: PM:10467584.

PIAZZA, P. V.; ROUGE-PONT, F.; DEROCHE, V.; MACCARI, S.; SIMON, H. e LE, M. M. Glucocorticoids have state-dependent stimulant effects on the mesencephalic dopaminergic transmission. Proc.Natl.Acad.Sci.U.S.A v. 93, n. 16, p. 8716-8720, Aug 6 1996. Disponível em: PM:8710937.

RAO, M. S.; HATTIANGADY, B. e SHETTY, A. K. Status epilepticus during old age is not associated with enhanced hippocampal neurogenesis. Hippocampus v. 18, n. 9, p. 931-944, 2008. Disponível em: PM:18493929.

RENEMAN, L.; ENDERT, E.; DE, B. K.; LAVALAYE, J.; FEENSTRA, M. G.; DE WOLFF, F. A. e BOOIJ, J. The acute and chronic effects of MDMA ("ecstasy") on cortical 5HT2A receptors in rat and human brain. Neuropsychopharmacology v. 26, n. 3, p. 387-396, Mar 2002. Disponível em: PM:11850153.

RESSTEL, L. B.; LISBOA, S. F.; AGUIAR, D. C.; CORREA, F. M. e GUIMARAES, F. S. Activation of CB1 cannabinoid receptors in the dorsolateral periaqueductal gray reduces the expression of contextual fear conditioning in rats. Psychopharmacology (Berl) v. 198, n. 3, p. 405-411, Jun 2008. Disponível em: PM:18446325.

RIBEIRO, R. L.; ANDREATINI, R.; WOLFMAN, C.; VIOLA, H.; MEDINA, J. H. e DA, C. $\mathrm{C}$. The "anxiety state" and its relation with rat models of memory and habituation.

Neurobiol.Learn.Mem. v. 72, n. 2, p. 78-94, Sep 1999. Disponível em: PM:10438649.

RICHARDSON-JONES, J. W.; CRAIGE, C. P.; GUIARD, B. P.; STEPHEN, A.; METZGER, K. L.; KUNG, H. F.; GARDIER, A. M.; DRANOVSKY, A.; DAVID, D. J.; 
BECK, S. G.; HEN, R. e LEONARDO, E. D. 5-HT1A autoreceptor levels determine vulnerability to stress and response to antidepressants. Neuron v. 65, n. 1, p. 40-52, Jan 14 2010. Disponível em: PM:20152112.

RONCON, C. M.; BIESDORF, C.; SANTANA, R. G.; ZANGROSSI, H., JR.; GRAEFF, F. G. e AUDI, E. A. The panicolytic-like effect of fluoxetine in the elevated T-maze is mediated by serotonin-induced activation of endogenous opioids in the dorsal periaqueductal grey. J.Psychopharmacol. v. 26, n. 4, p. 525-531, Apr 2012. Disponível em: PM:22279131.

ROOZENDAAL, B.; MCEWEN, B. S. e CHATTARJI, S. Stress, memory and the amygdala. Nat.Rev.Neurosci. v. 10, n. 6, p. 423-433, Jun 2009. Disponível em: PM:19469026.

ROTH, B. L.; PALVIMAKI, E. P.; BERRY, S.; KHAN, N.; SACHS, N.; ULUER, A. e CHOUDHARY, M. S. 5-Hydroxytryptamine2A (5-HT2A) receptor desensitization can occur without down-regulation. J.Pharmacol.Exp.Ther. v. 275, n. 3, p. 1638-1646, Dec 1995. Disponível em: PM:8531139.

SAGAR, S. M.; SHARP, F. R. e CURRAN, T. Expression of c-fos protein in brain: metabolic mapping at the cellular level. Science v. 240, n. 4857, p. 1328-1331, Jun 3 1988. Disponível em: PM:3131879.

SAJDYK, T. J.; SCHOBER, D. A.; GEHLERT, D. R. e SHEKHAR, A. Role of corticotropinreleasing factor and urocortin within the basolateral amygdala of rats in anxiety and panic responses. Behav.Brain Res. v. 100, n. 1-2, p. 207-215, Apr 1999. Disponível em: PM:10212068.

SALOME, N.; SALCHNER, P.; VILTART, O.; SEQUEIRA, H.; WIGGER, A.; LANDGRAF, R. e SINGEWALD, N. Neurobiological correlates of high (HAB) versus low anxiety-related behavior (LAB): differential Fos expression in HAB and LAB rats.

Biol.Psychiatry v. 55, n. 7, p. 715-723, Apr 1 2004. Disponível em: PM:15039000.

SANDI, C. e BISAZ, R. A model for the involvement of neural cell adhesion molecules in stress-related mood disorders. Neuroendocrinology v. 85, n. 3, p. 158-176, 2007. Disponível em: PM:17409734.

SANDI, C.; CORDERO, M. I.; UGOLINI, A.; VAREA, E.; CABERLOTTO, L. e LARGE, C. H. Chronic stress-induced alterations in amygdala responsiveness and behavior-modulation by trait anxiety and corticotropin-releasing factor systems. Eur.J.Neurosci. v. 28, n. 9, p. 1836-1848, Nov 2008. Disponível em: PM:18973598.

SANDI, C.; MERINO, J. J.; CORDERO, M. I.; KRUYT, N. D.; MURPHY, K. J. e REGAN, C. M. Modulation of hippocampal NCAM polysialylation and spatial memory consolidation by fear conditioning. Biol.Psychiatry v. 54, n. 6, p. 599-607, Sep 15 2003. Disponível em: PM:13129654. 
SANDI, C. e PINELO-NAVA, M. T. Stress and memory: behavioral effects and neurobiological mechanisms. Neural Plast. v. 2007, p. 78970, 2007. Disponível em: PM:18060012.

SANDI, C. e RICHTER-LEVIN, G. From high anxiety trait to depression: a neurocognitive hypothesis. Trends Neurosci. v. 32, n. 6, p. 312-320, Jun 2009. Disponível em: PM:19409624.

SAXE, M. D.; BATTAGLIA, F.; WANG, J. W.; MALLERET, G.; DAVID, D. J.; MONCKTON, J. E.; GARCIA, A. D.; SOFRONIEW, M. V.; KANDEL, E. R.; SANTARELLI, L.; HEN, R. e DREW, M. R. Ablation of hippocampal neurogenesis impairs contextual fear conditioning and synaptic plasticity in the dentate gyrus.

Proc.Natl.Acad.Sci.U.S.A v. 103, n. 46, p. 17501-17506, Nov 14 2006. Disponível em: PM:17088541.

SCHOLZEN, T. e GERDES, J. The Ki-67 protein: from the known and the unknown. J.Cell Physiol v. 182, n. 3, p. 311-322, Mar 2000. Disponível em: PM:10653597.

SCHULKIN, J.; GOLD, P. W. e MCEWEN, B. S. Induction of corticotropin-releasing hormone gene expression by glucocorticoids: implication for understanding the states of fear and anxiety and allostatic load. Psychoneuroendocrinology v. 23, n. 3, p. 219-243, Apr 1998. Disponível em: PM:9695128.

SCHULKIN, J.; MCEWEN, B. S. e GOLD, P. W. Allostasis, amygdala, and anticipatory angst. Neurosci.Biobehav.Rev. v. 18, n. 3, p. 385-396, 1994. Disponível em: PM:7984356.

SCHUTZ, M. T.; DE AGUIAR, J. C. e GRAEFF, F. G. Anti-aversive role of serotonin in the dorsal periaqueductal grey matter. Psychopharmacology (Berl) v. 85, n. 3, p. 340-345, 1985. Disponível em: PM:3159032.

SCHUURMANS, J. CBT, SSRI or both are similarly effective for panic disorder 1-year posttreatment. Evid.Based.Ment.Health Oct 7 2010. Disponível em: PM:20930038.

SELIGMAN, M. E. e BEAGLEY, G. Learned helplessness in the rat. J.Comp Physiol Psychol. v. 88, n. 2, p. 534-541, Feb 1975. Disponível em: PM:1150935.

SELYE, H. The nature of stress. Basal.Facts. v. 7, n. 1, p. 3-11, 1985. Disponível em: PM:2990402.

SHEKHAR, A. GABA receptors in the region of the dorsomedial hypothalamus of rats regulate anxiety in the elevated plus-maze test. I. Behavioral measures. Brain Res. v. 627, n. 1, p. 9-16, Nov 5 1993. Disponível em: PM:8293308.

SHEKHAR, A. e KATNER, J. S. Dorsomedial hypothalamic GABA regulates anxiety in the social interaction test. Pharmacol.Biochem.Behav. v. 50, n. 2, p. 253-258, Feb 1995. Disponível em: PM:7740065. 
SHERMAN, A. D. e PETTY, F. Neurochemical basis of the action of antidepressants on learned helplessness. Behav.Neural Biol. v. 30, n. 2, p. 119-134, Oct 1980. Disponível em: PM:6108760.

SILVEIRA, M. C.; ZANGROSSI, H.; DE, B., V; SILVEIRA, R. e GRAEFF, F. G. Differential expression of Fos protein in the rat brain induced by performance of avoidance or escape in the elevated T-maze. Behav.Brain Res. v. 126, n. 1-2, p. 13-21, Nov 292001. Disponível em: PM:11704247.

SINGEWALD, N. Altered brain activity processing in high-anxiety rodents revealed by challenge paradigms and functional mapping. Neurosci.Biobehav.Rev. v. 31, n. 1, p. 18-40, 2007. Disponível em: PM:16620984.

SKORZEWSKA, A.; BIDZINSKI, A.; LEHNER, M.; TURZYNSKA, D.; SOBOLEWSKA, A.; HAMED, A.; SZYNDLER, J.; MACIEJAK, P. e PLAZNIK, A. The effects of acute corticosterone administration on anxiety, endogenous corticosterone, and c-Fos expression in the rat brain. Horm.Behav. v. 52, n. 3, p. 317-325, Sep 2007. Disponível em: PM:17594906.

SMITH, R. L.; BARRETT, R. J. e SANDERS-BUSH, E. Mechanism of tolerance development to 2,5-dimethoxy-4-iodoamphetamine in rats: down-regulation of the 5-HT2A, but not 5-HT2C, receptor. Psychopharmacology (Berl) v. 144, n. 3, p. 248-254, Jun 1999. Disponível em: PM:10435391.

STANLEY, M. e MANN, J. J. Increased serotonin-2 binding sites in frontal cortex of suicide victims. Lancet v. 1, n. 8318, p. 214-216, Jan 29 1983. Disponível em: PM:6130248.

STERN, C. A.; DO MONTE, F. H.; GAZARINI, L.; CAROBREZ, A. P. e BERTOGLIO, L. $\mathrm{J}$. Activity in prelimbic cortex is required for adjusting the anxiety response level during the elevated plus-maze retest. Neuroscience v. 170, n. 1, p. 214-222, Sep 29 2010. Disponível em: PM:20620194.

SZABO, S. T. e BLIER, P. Effects of serotonin (5-hydroxytryptamine, 5-HT) reuptake inhibition plus 5-HT(2A) receptor antagonism on the firing activity of norepinephrine neurons. J.Pharmacol.Exp.Ther. v. 302, n. 3, p. 983-991, Sep 2002. Disponível em: PM:12183655.

TALLMAN, J. F.; PAUL, S. M.; SKOLNICK, P. e GALLAGER, D. W. Receptors for the age of anxiety: pharmacology of the benzodiazepines. Science v. 207, n. 4428, p. 274-281, Jan 18 1980. Disponível em: PM:6101294.

TANAPAT, P.; HASTINGS, N. B.; RYDEL, T. A.; GALEA, L. A. e GOULD, E. Exposure to fox odor inhibits cell proliferation in the hippocampus of adult rats via an adrenal hormonedependent mechanism. J.Comp Neurol. v. 437, n. 4, p. 496-504, Sep 3 2001. Disponível em: PM:11503148.

THORELL, J. I. e LARSON, S. M. Radioimmunoassay and related techniques : methodology and clinical applications. Saint Louis: Mosby, 1978. 
TOUYAROT, K.; VENERO, C. e SANDI, C. Spatial learning impairment induced by chronic stress is related to individual differences in novelty reactivity: search for neurobiological correlates. Psychoneuroendocrinology v. 29, n. 2, p. 290-305, Feb 2004. Disponível em: PM:14604607.

TRENT, N. L. e MENARD, J. L. The ventral hippocampus and the lateral septum work in tandem to regulate rats' open-arm exploration in the elevated plus-maze. Physiol Behav. v. 101, n. 1, p. 141-152, Aug 4 2010. Disponível em: PM:20451539.

UCHIDA, S.; NISHIDA, A.; HARA, K.; KAMEMOTO, T.; SUETSUGI, M.; FUJIMOTO, M.; WATANUKI, T.; WAKABAYASHI, Y.; OTSUKI, K.; MCEWEN, B. S. e

WATANABE, Y. Characterization of the vulnerability to repeated stress in Fischer 344 rats: possible involvement of microRNA-mediated down-regulation of the glucocorticoid receptor. Eur.J.Neurosci v. 27, n. 9, p. 2250-2261, May 2008. Disponível em: PM:18445216.

VAIDYA, V. A.; MAREK, G. J.; AGHAJANIAN, G. K. e DUMAN, R. S. 5-HT2A receptormediated regulation of brain-derived neurotrophic factor mRNA in the hippocampus and the neocortex. J.Neurosci. v. 17, n. 8, p. 2785-2795, Apr 15 1997. Disponível em: PM:9092600.

VAN APELDOORN, F. J.; VAN HOUT, W. J.; MERSCH, P. P.; HUISMAN, M.; SLAAP, B. R.; HALE, W. W., III; VISSER, S.; VAN, D. R. e DEN BOER, J. A. Is a combined therapy more effective than either CBT or SSRI alone? Results of a multicenter trial on panic disorder with or without agoraphobia. Acta Psychiatr.Scand. v. 117, n. 4, p. 260-270, Apr 2008. Disponível em: PM:18307586.

VAN, P. H.; SCHINDER, A. F.; CHRISTIE, B. R.; TONI, N.; PALMER, T. D. e GAGE, F. H. Functional neurogenesis in the adult hippocampus. Nature v. 415, n. 6875, p. 1030-1034, Feb 28 2002. Disponível em: PM:11875571.

VEENEMA, A. H.; DE KLOET, E. R.; DE WILDE, M. C.; ROELOFS, A. J.; KAWATA, M.; BUWALDA, B.; NEUMANN, I. D.; KOOLHAAS, J. M. e LUCASSEN, P. J. Differential effects of stress on adult hippocampal cell proliferation in low and high aggressive mice. J.Neuroendocrinol. v. 19, n. 7, p. 489-498, Jul 2007. Disponível em: PM:17561881.

WARNER-SCHMIDT, J. L. e DUMAN, R. S. Hippocampal neurogenesis: opposing effects of stress and antidepressant treatment. Hippocampus v. 16, n. 3, p. 239-249, 2006.

Disponível em: PM:16425236.

WEISS, J. M.; BAILEY, W. H.; POHORECKY, L. A.; KORZENIOWSKI, D. e GRILLIONE, G. Stress-induced depression of motor activity correlates with regional changes in brain norepinephrine but not in dopamine. Neurochem.Res. v. 5, n. 1, p. 9-22, Jan 1980. Disponível em: PM:7366796.

WEISS, J. M. e GLAZER, H. I. Effects of acute exposure to stressors on subsequent avoidance-escape behavior. Psychosom.Med. v. 37, n. 6, p. 499-521, Nov 1975. Disponível em: PM:1239037. 
WEISS, J. M.; GLAZER, H. I.; POHORECKY, L. A.; BRICK, J. e MILLER, N. E. Effects of chronic exposure to stressors on avoidance-escape behavior and on brain norepinephrine.

Psychosom.Med. v. 37, n. 6, p. 522-534, Nov 1975. Disponível em: PM:711.

WIELAND, S.; BOREN, J. L.; CONSROE, P. F. e MARTIN, A. Stock differences in the susceptibility of rats to learned helplessness training. Life Sci. v. 39, n. 10, p. 937-944, Sep 8 1986. Disponível em: PM:3489150.

WISE, C. D.; BERGER, B. D. e STEIN, L. Benzodiazepines: anxiety-reducing activity by reduction of serotonin turnover in the brain. Science v. 177, n. 44, p. 180-183, Jul 141972. Disponível em: PM:5064914.

WOJTOWICZ, J. M. e KEE, N. BrdU assay for neurogenesis in rodents. Nat.Protoc. v. 1, n. 3, p. 1399-1405, 2006. Disponível em: PM:17406427.

XU, Y.; KU, B.; TIE, L.; YAO, H.; JIANG, W.; MA, X. e LI, X. Curcumin reverses the effects of chronic stress on behavior, the HPA axis, BDNF expression and phosphorylation of CREB. Brain Res. v. 1122, n. 1, p. 56-64, Nov 29 2006. Disponível em: PM:17022948.

YAMAUCHI, M.; MIYARA, T.; MATSUSHIMA, T. e IMANISHI, T. Desensitization of 5HT2A receptor function by chronic administration of selective serotonin reuptake inhibitors. Brain Res. v. 1067, n. 1, p. 164-169, Jan 5 2006. Disponível em: PM:16360124.

YERKES, R. M. e DODSON, J. D. The relation of strength of stimulus to rapidity of habitformation. Journal of Comparative Neurology and Psychology v. 18, n. 5, p. 459-482, Nov 1 1908. Disponível em: http://dx.doi.org/10.1002/cne.920180503.

YU, I. T.; LEE, S. H.; LEE, Y. S. e SON, H. Differential effects of corticosterone and dexamethasone on hippocampal neurogenesis in vitro. Biochem.Biophys.Res.Commun. v. 317, n. 2, p. 484-490, Apr 30 2004. Disponível em: PM:15063783.

ZANGROSSI, J. H. e GRAEFF, F. G. Behavioral effects of intra-amygdala injections of GABA and 5-HT acting drugs in the elevated plus-maze. Braz.J.Med.Biol.Res. v. 27, n. 10, p. 2453-2456, Oct 1994. Disponível em: PM:7640637.

ZANOVELI, J. M.; NOGUEIRA, R. L. e ZANGROSSI, H., JR. Chronic imipramine treatment sensitizes 5-HT1A and 5-HT 2 A receptors in the dorsal periaqueductal gray matter: evidence from the elevated T-maze test of anxiety. Behav.Pharmacol. v. 16, n. 7, p. 543-552, Nov 2005. Disponível em: PM:16170231.

ZHAO, Y.; MA, R.; SHEN, J.; SU, H.; XING, D. e DU, L. A mouse model of depression induced by repeated corticosterone injections. Eur.J.Pharmacol. v. 581, n. 1-2, p. 113-120, Feb 26 2008. Disponível em: PM:18184609.

ZHAO, Y.; PATZER, A.; HERDEGEN, T.; GOHLKE, P. e CULMAN, J. Activation of cerebral peroxisome proliferator-activated receptors gamma promotes neuroprotection by 
attenuation of neuronal cyclooxygenase-2 overexpression after focal cerebral ischemia in rats. FASEB J. v. 20, n. 8, p. 1162-1175, Jun 2006. Disponível em: PM:16770015. 